UNIVERSIDADE DE SÃO PAULO

FACULDADE DE MEDICINA DE RIBEIRÃO PRETO

PROGRAMA DE PÓS GRADUAÇÃO

MESTRADO PROFISSIONAL EM HEMOTERAPIA E BIOTECNOLOGIA

CIBELE ANGÉLICA DE SOUZA SPINA

SIDEROPENIA EM DOADORES DE SANGUE DA

UNIDADE DA FUNDAÇÃO HEMOMINAS DE POÇOS DE

CALDAS

RIBEIRÃO PRETO

2019 


\section{CIBELE ANGÉLICA DE SOUZA SPINA}

\section{SIDEROPENIA EM DOADORES DE SANGUE DA UNIDADE DA FUNDAÇÃO HEMOMINAS DE POÇOS DE CALDAS}




\title{
SIDEROPENIA EM DOADORES DE SANGUE DA UNIDADE DA FUNDAÇÃO HEMOMINAS DE POÇOS DE CALDAS
}

\author{
Versão original
}

Dissertação apresentada ao Programa de Mestrado Profissional em Hemoterapia e Biotecnologia, área de Hemoterapia e Medicina Transfusional da Faculdade de Medicina de Ribeirão Preto da Universidade de São Paulo para obtenção de título de Mestre em Ciências

Área de Concentração: Hemoterapia

Orientador: Dr. Gil Cunha de Santis 
AUTORIZO A REPRODUÇÃO E DIVULGAÇÃO TOTAL OU PARCIAL DESTE TRABALHO, POR QUALQUER MEIO CONVENCIONAL OU ELETRÔNICO, PARA FINS DE ESTUDO E PESQUISA, DESDE QUE CITADA A FONTE.

FICHA CATALOGRÁFICA

Spina, Cibele Angélica de Souza

Sideropenia em doadores de sangue da unidade da Fundação Hemominas de Poços de Caldas

Ribeirão Preto, 2019.

$80 f$.

Dissertação de mestrado apresentada à Faculdade de Medicina de Ribeirão Preto, Universidade de São Paulo.

Área de concentração: Hemoterapia e Medicina Transfusional Orientador:

Santis, Gil Cunha
1. Anemia
2. Sideropenia
3. Ferritina
4. Doador de Sangue 


\section{FOLHA DE APROVAÇÃO}

SPINA, C.A.S. Sideropenia em doadores de sangue na unidade da Fundação Hemominas de Poços de Caldas. 2019. 80f. Dissertação de Mestrado

Profissional em Hemoterapia e Biotecnologia - Faculdade de Medicina de

Ribeirão Preto, Universidade de São Paulo, Ribeirão Preto, 2019.

Aprovado em:

\section{Banca Examinadora}

Prof. Dr.

Instituição:

Julgamento:

Prof. Dr.

Instituição:

Julgamento:

Prof. Dr.

Instituição:

Julgamento:

Prof. Dr.

Instituição:

Julgamento: 
Dedico esse trabalho a minha mãe Antônia por ter me incentivado, como só ela sabe fazer, em toda minha caminhada. 


\section{AGRADECIMENTOS}

A Deus, por me proporcionar inúmeras oportunidades de estar viva, tornando todos os dias o impossível possível,

À Santa Clara, por ser minha protetora e parceira de jornada,

Aos meus pais, Antonia e Humberto por me darem condições moral, física e espiritual para chegar até aqui, e principalmente por acreditarem em mim,

Ao meu orientador Dr. Gil, por aceitar ser meu orientador, e me ensinar muito além dessa dissertação. Muito obrigado Professor,

À Dra Eugênia, por não me deixar desistir e por literalmente pegar nas minhas mãos nessa jornada,

Ao Prof.Dr. Rodrigo Calado, por me proporcionar conforto e segurança quando passei por momentos de tormenta no trajeto,

Ao meu amigo, companheiro, parceiro de todas as horas, Juliano, por toda força, por segurar a barra esses três anos diretamente, por todo conhecimento, inteligência e tudo mais, para que esse trabalho pudesse chegar no seu fim,

À minha colega de Mestrado Aline, por ter sido a fonte de inspiração para esse trabalho,

Ao Flávio Togni, secretário de saúde de Poços de Caldas, por tornar esse projeto viável,

À toda equipe da Policlínica Central de Poços de Caldas, pelo apoio incondicional de vocês. Bel e Diego, quando crescer quero ser igual vocês,

À Claudiele, por ter me ajudado a processar cada amostra e principalmente, me manter confiante,

À equipe de triagistas, Laura, Marta e Rodrigo, muito obrigada., vocês tiveram toda paciência possível,

Ao meu querido e para sempre chefe Fernando Basques por tudo que representou nesse projeto e em grade parte da minha trajetória profissional,

À Fundação Hemominas, instituição da qual tenho o privilégio de estar, em nome da Presidenta Dra.Júnia, por todo apoio,

Aos doadores que participaram dessa pesquisa e a todos que diariamente comparecem em todas as unidades de doação do mundo com o único intuito de doar. Gratidão, 


\section{AGRADECIMENTOS}

Aos colegas do Mestrado, por todos os momentos que passamos juntos.

À Nazaré, por estar presente em nossas vidas, obrigada por toda dedicação e carinho com que sempre cuidou de cada detalhe em nossas vidas,

Ao meu irmão Jonas, que mesmo longe me ajuda direta e indiretamente em toda a minha jornada de vida,

Ao meu irmão Tiago e a minha cunhada Plínia, por principalmente serem companheiros da minha filha nesse momento de total ausência,

À minha filha Laura, por existir. Te amo. 
"Amar é doar-se por completo, e ainda assim permanecer inteiro"

Edna Frigato 


\section{RESUMO}

SPINA, C.A.S. Sideropenia em doadores de sangue na unidade da Fundação Hemominas de Poços de Caldas. 2019. 80f. Dissertação de Mestrado Profissional em Hemoterapia e Biotecnologia - Faculdade de Medicina de Ribeirão Preto, Universidade de São Paulo, Ribeirão Preto, 2019.

Introdução: O primeiro estágio da anemia ferropriva é a depleção de ferro, ou sideropenia. A deficiência latente de ferro no organismo em geral resulta de perdas sanguíneas, fisiológicas ou patológicas, como menstruação, epistaxe, hemorróidas e doação de sangue. Foi demonstrado que após doação de $450 \mathrm{~mL}$ de sangue, doadores do sexo masculino perdem $242 \pm 17 \mathrm{mg}$ de ferro e do sexo feminino, $217 \pm 11 \mathrm{mg}$. De acordo com o metabolismo e a absorção de ferro pelo organismo, a recuperação desse montante perdido com a doação de sangue pode demorar até um ano em indivíduos com dieta quantitativamente ideal de ferro. Objetivos: Conhecer a prevalência de depleção de ferro na população doadora de sangue na Unidade da Fundação Hemominas de Poços de Caldas e correlacionar a concentração da ferritina sérica, a hematimetria com o histórico de doações com as características dos doadores sem anemia e com ferritina normal com os doadores sem anemia e com ferritina baixa. Materias e métodos: Foram consideradas amostras de sangue para exame de ferritina de 986 doadores de sangue, primodoadores e de doadores de repetição. Também foi aplicado questionário para investigação de fatores de depleção de ferro, como doações anteriores, anemia anterior, hábitos alimentares, uso de vitaminas, uso de álcool e cigarro de papel, histórico ginecológico, presença de comorbidades e levantamento de valores de hemoglobina ou de hematócrito das doações anteriores, no caso de doadores de repetição, para comparação com os valores de ferritina. Resultados: Dos 986 doadores, 594 homens e 392 mulheres, 163 apresentaram depleção de ferro (ferritina $<30 \mathrm{ng} / \mathrm{mL}$ )., dos quais $66,6 \%$ eram mulheres, ou seja, o dobro da depleção apresentada em homens, apesar dos homens doarem mais frequentemente que as mulheres. Sendo assim mulheres em idade fértil constituem um grupo de risco para depleção de ferro, e que as triagens clínica e hematológicas não suficientes para detectar, talvez mereçam algum grau de suplementação de ferro, que poderá ser avaliado em um estudo futuro.

Palavras Chave: Anemia. Doador de sangue. Sideropenia. Ferritina. 
SPINA, C.A.S. Sideropenia in blood donors in the unit of the Hemominas Foundation of Poços de Caldas. 2019 80f. Professional Master's thesis in Hemotherapy and Biotechnology - Faculty of Medicine of Ribeirão Preto, University of São Paulo, Ribeirão Preto, 2019.

Introduction: The first stage of iron deficiency anemia is iron depletion, or sideropenia. The latent deficiency of iron in the body usually results from blood loss, physiological or pathological, such as menstruation, epistaxis, hemorrhoids and blood donation. It was shown that after donation of $450 \mathrm{ml}$ of blood, male donors lost $242 \pm$ $17 \mathrm{mg}$ of iron and female, $217 \pm 11 \mathrm{mg}$. According to the body's metabolism and absorption of iron, recovering this amount lost with blood donation can take up to a year in individuals with a quantitatively ideal diet of iron. Objectives: To know the prevalence of iron depletion in the blood donor population in the Hemominas Foundation Unit in Poços de Caldas and to correlate the serum ferritin concentration, the hematimetry with the donation history with donor characteristics without anemia and with normal ferritin with donors without anemia and low ferritin. Materials and methods: Blood samples were taken for ferritin from 986 blood donors, primers, and repeat donors. A questionnaire was also used to investigate iron depletion factors, such as previous donations, previous anemia, eating habits, use of vitamins, alcohol and paper cigarettes, gynecological history, presence of comorbidities, and hemoglobin or hematocrit values of the previous donations, in the case of repeat donors, for comparison with ferritin values. Results: Of the 986 donors, 594 men and 392 women, 163 presented iron depletion (ferritin $<30 \mathrm{ng} / \mathrm{mL}$ ), of which $66.6 \%$ were women, that is, twice the depletion presented in men, despite men more often than women. Thus, women of childbearing age are a risk group for iron depletion, and clinical and hematological screenings not sufficient to detect may merit some degree of iron supplementation, which can be evaluated in a future study.

Keywords: Anemia. Blood donator. Sideropenia. Ferritin. 


\section{LISTA DE FIGURAS}

Figura 1 - Hemovigilância em hemoterapia .................................... 28

Figura 2 - Necessidade e perdas de ferro pelo organismo ..................... 32

Figura 3 - Fases de depleção de ferro .................................................. 34 
Tabela 1 - Dados quantitativos sobre metabolismo normal de ferro

Tabela 2 - Relação entre sexo, concentração de ferritina $(\mathrm{ng} / \mathrm{mL})$, hemoglobina $(\mathrm{Hb})$ e número de doações

Tabela 3 - Comparação das participantes femininas de acordo com seu histórico transfusional

Tabela 4 - Comparação dos participantes masculinos de acordo com seu histórico transfusional

Tabela 5 - Comparação do grupo das mulheres de acordo com sua alimentação

Tabela 6 - Comparação do grupo dos homens de acordo com sua alimentação

Tabela 7 - Comparação das participantes femininas em relação ao uso de suplementos

Tabela 8 - Comparação dos participantes masculinos em relação ao uso de suplementos

Tabela 9 - Comparação das participantes femininas de acordo com seus hábitos de vida e sócio-culturais

Tabela 10 - Comparação dos participantes masculinos de acordo com seus hábitos de vida e sócio-culturais

Tabela 11 - Comparação das concentrações de ferritina de acordo com a estratificação do índice de massa corporal nas mulheres

Tabela 12 - Comparação das participantes femininas de acordo com o histórico obstétrico

Tabela 13 - Comparação dos participantes femininas de acordo com a presença de anemia prévia e tratamento com ferro.

Tabela 14 - Comparação entre os grupos femininos de acordo com a presença de comorbidades.

Tabela 15 - Comparação das concentrações de ferritina de acordo com a estratificação do índice de massa corporal nos homens

Tabela 16 - Comparação dos homens em relação a presença de anemia prévia e tratamento com ferro

Tabela 17 - Comparação entre os grupos masculinos de acordo com a presença de comorbidades 
Tabela 18 - Relação entre concentração de ferritina encontrada de acordo com a faixa etária das doadoras do sexo feminino

Tabela 19 - Relação entre concentração de ferritina encontrada de acordo com a faixa etária dos doadores do sexo masculino

Tabela 20 - Comparação dos primodoadores entre os grupos masculinos e femininos

Tabela 21 - Frequência observada dos grupos femininos com ferritina $<30$ $\mathrm{ng} / \mathrm{mL}(\mathrm{A})$, ferritina $30 \mathrm{a} 60 \mathrm{ng} / \mathrm{mL}$ (B), ferritina $>60 \mathrm{ng} / \mathrm{mL}$ (C), com os masculinos portadores de ferritina $<30 \mathrm{ng} / \mathrm{mL}$ (D) , ferritina 30 a $60 \mathrm{ng} / \mathrm{mL}$ (E) , ferritina $>60 \mathrm{ng} / \mathrm{mL}(\mathrm{F})$

Tabela 22 - Resultado hemoglobina x intervalo de ferritina x sexo

Tabela 23 - Doadores por número de doações e sexo - Vries.

Tabela 24 - Resultado dos exames laboratoriais realizados 
AABB American Association of Blood Banks

CAAE Certificado de Apresentação para Apreciação Ética

CNS Conselho Nacional de Saúde

EUA Estados Unidos da América

IMC Índice de Massa Corpórea

ISBT Internacional Society of Blood Transfusion

MS Ministério da Saúde

NHANES National Health and Nutrition Examination Survey)

REDS Recipient Epidemiology and Donor Evaluation Study

SHOT Serious Hazard of Transfusion

UIBC Unsaturated Iron Binding Capacity

WHO World Health Organization 


\section{LISTA DE SÍMBOLOS}

$\begin{array}{ll}\mathbf{d L} & \text { Decilitros } \\ \mathbf{F e}+^{2} & \text { ĺon ferroso } \\ \mathbf{F e}+^{3} & \text { ĺon férrico } \\ \mathbf{g} & \text { Gramas por decilitro } \\ \mathbf{H b} & \text { Hemoglobina } \\ \mathbf{k D} & \text { Kilo Dalton } \\ \mathbf{K g} & \text { Kilogramas } \\ \mathbf{m g} & \text { Miligramas } \\ \mathbf{m L} & \text { Mililitros } \\ \mathbf{n g} & \text { Nanogramas } \\ \mathbf{\mathbf { O } _ { 2 }} & \text { Oxigênio } \\ \mathbf{\mu g} & \text { Micrograma }\end{array}$




\section{LISTA DE GRÁFICOS}

Gráfico 1 - Representação das frequências das participantes do estudo do sexo feminino de acordo com a quantidade de doações e a concentração de ferritina encontrada

Gráfico 2 - Representação das frequências dos participantes do estudo do sexo masculino de acordo com a quantidade de doações e a concentração de ferritina encontrada

Gráfico 3 - Representação das frequências dos participantes do estudo do sexo feminino de acordo com o consumo de carne, o tipo, numero de porções e a média de doações.

Gráfico 4 - Representação das frequências dos participantes do estudo do sexo masculino de acordo com o IMC e concentração de ferritina sérica.

Gráfico 5 - Representação entre intervalos de ferritina e percentual de mulheres doadoras.

Gráfico 6 - Representação das frequências das participantes do estudo em relação à concentração de hemoglobina e ferritina sérica.

Gráfico 7 - Representação das frequências das participantes do estudo do sexo feminino de acordo com a idade e concentração de ferritina encontrada.

Gráfico 8 - O ferro armazenado em comparação com a perda da doação de uma unidade de sangue total relatada pelos estudos indicados por Cable et al em 2016 e Kiss et al 2017.

Gráfico 9 - Representação das frequências dos participantes quanto ao número de doações 


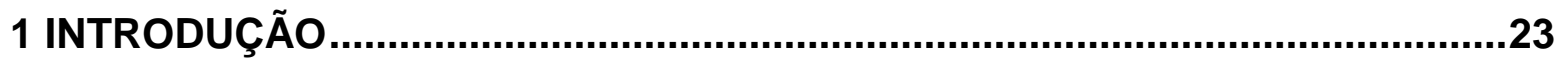

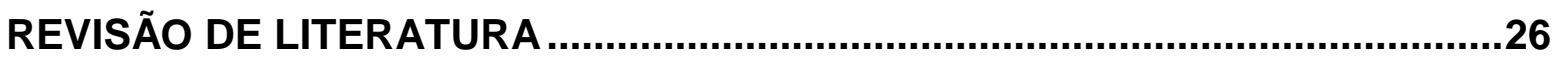

3 OBJETIVOS

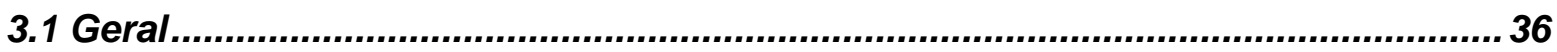

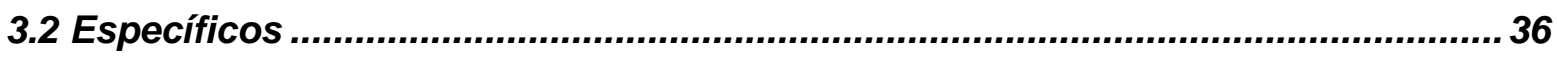

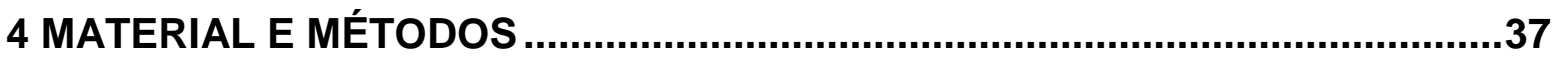

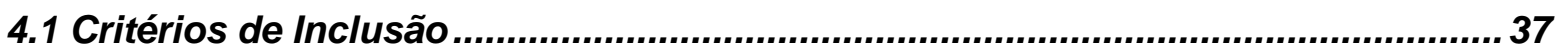

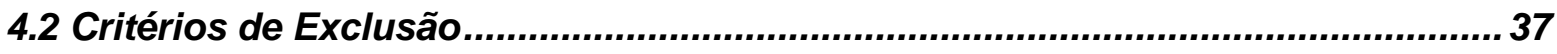

4.3 Variáveis

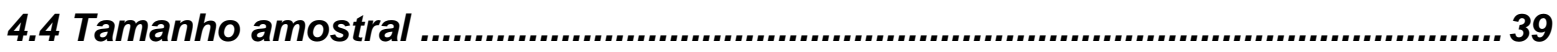

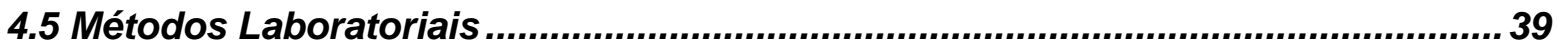

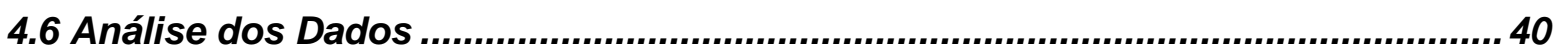

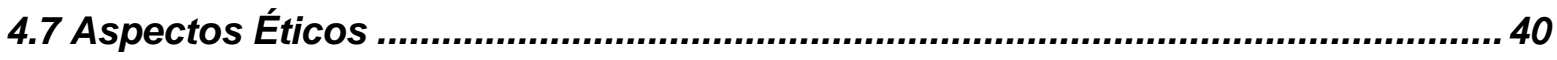

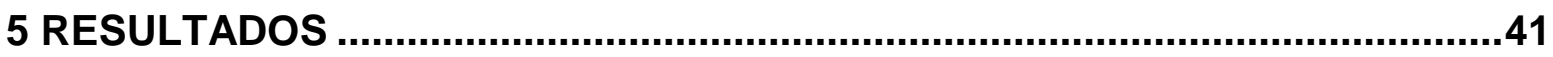

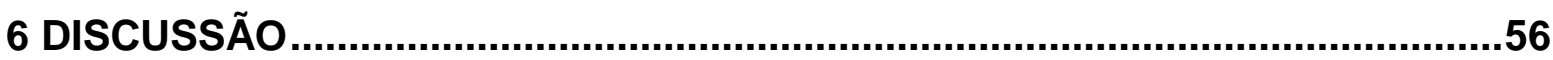

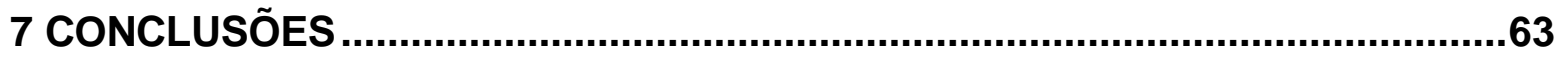

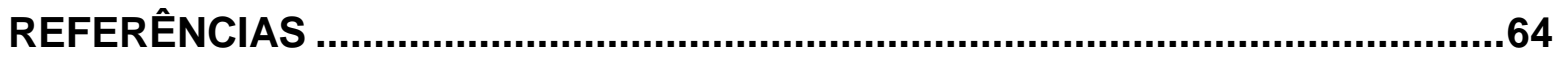

APÊNDICE A - Termo de Consentimento Livre e Esclarecido ..........................69

CONSENTIMENTO PÓS INFORMADO …........................................................

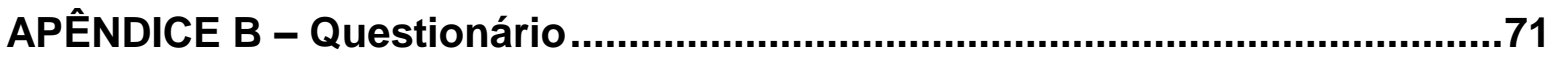

ANEXO A - Regimento Institucional de Biorrepositório .....................................74

ANEXO B - Parecer consubstanciado do CEP ............................................76 


\section{INTRODUÇÃO}

Uma preocupação importante dos grandes centros de hemoterapia no mundo é a segurança do doador e do paciente. Considerando alguns sistemas de hemovigilância do mundo, a exemplo do SHOT (Serious Hazard of Transfusion), que produz recomendações aos serviços de saúde do Reino Unido após coletar e analisar as informações sobre os eventos adversos e reações transfusionais. No Brasil, em 2015 houve a implantação de um sistema semelhante, após o lançamento do Marco Conceitual e Operacional de Hemovigilância: Guia para a Hemovigilância do Brasil em 2015 (BRASIL, 2015), pois antes dessa publicação a hemovigilância resumia-se a investigação e monitoramento das reações ocorridas durante ou após as transfusões. O marco amplia o escopo da hemovigilância uma vez que abrange todo o ciclo do sangue.

O Marco Conceitual traz um capítulo sobre a hemovigilância do doador, que pontua todos os eventos adversos imediatos que podem ocorrer antes, durante e após a doação de sangue (BRASIL,2015), no entanto, não aborda uma das principais reações tardias ao doador, que é a sideropenia em doadores de repetição.

Essa complicação da doação já havia sido observada na década de 50, quando em uma investigação do metabolismo do ferro em 297 doadores voluntários, verificou que a partir da décima doação havia significativas diferenças entre doadores do sexo masculino e feminino, demonstrando que $22 \%$ das mulheres desse estudo apresentaram sideropenia latente enquanto nos homens apenas 6\%. (VRIES, 1958).

Em outro estudo mais recente, realizado no Centro de Medicina Laboratorial da Santa Casa de Limeira, foram investigados 100 doadores aptos para a doação de sangue, sendo 50 homens e 50 mulheres com idade entre 18 e 55 anos, incluindo doadores de repetição e de primeira vez. Foi realizada dosagem de ferritina, dosagem do ferro sérico e da transferrina e se observou que $26 \%$ dos doadores apresentavam ferro abaixo de $60 \mu \mathrm{g} / \mathrm{dL}$ e $56 \%$ ferritina abaixo de 12 $\mathrm{ng} / \mathrm{mL}$. O autor concluiu que a doação de sangue pode causar uma deficiência de ferro nos doadores, em especial, nas mulheres que doam mais de uma vez por ano (BRANDINO, 2007). 
Dada a importância do tema, em 17 de março de 2017 a AABB (American Association of Blood Banks) publicou um boletim com três estudos significativos sobre a depleção de ferro no doador de sangue, e incluiu recomendações significativas para a redução dessa complicação, dentre elas: preparação de materiais educativos aos doadores alertando sobre a possibilidade de depleção de ferro e algumas formas de intervenção, atenção aos grupos com maior risco da complicação e o monitoramento depois da implementação das medidas. (AABB,2019)

No entanto, a depleção do ferro, também conhecida como sideropenia, pode ocorrer em outras situações como: dieta pobre em ferro, verminoses, síndromes de má absorção, hemorragias de causas diversas como: hematúria, hemorroidas, câncer e úlceras (BRITTENHAM, 1995). É importante afastar no doador a presença dessas situações para se afirmar que a doação, por si, estaria provocando a ferropenia.

Já foi demonstrado que após doação de $450 \mathrm{~mL}$ de sangue, doadores do sexo masculino perdem $242 \pm 17 \mathrm{mg}$ de ferro e do sexo feminino, $217 \pm 11 \mathrm{mg}$ de ferro (KESSLER et al, 1999; POPOVSKY,2012). A perda de ferro que ocorre em uma doação de sangue, implicará queda do estoque de ferro corporal (SIMON et al., 1981; AGHA, 1989; CANÇADO et al., 2001). Após a doação de sangue haverá uma depleção de ferro (BOULTON, 2000).

A depleção de ferro ocorrida em uma doação de $450 \mathrm{~mL}$ de sangue demandará em média 24 semanas para ser suprida por uma dieta com as medidas diárias recomendadas de ferro, sem suplementação, podendo acarretar, principalmente em doadores de repetição e fidelizados, deficiência de ferro (KISS, 2018).

Há vários métodos para verificar a depleção de ferro no organismo, como: dosagem de ferritina, dosagem de zincoprotoporfirina, transferrina. (CABLE et al., 2012). No entanto a dosagem de ferritina é considerado um bom marcador para estimar a deficiência do ferro, por ser um método barato e eficaz. (LIPSCHITZ,1974). O inconveniente da dosagem da ferritica reside no fato de essa proteína ter seus níveis elevados em doenças inflamatórias, quando então seu valor deixa de ter correlação com as reservas de ferro (KELL,2014)

\section{Justificativa}

A depleção de ferro no doador de sangue total é um assunto que está sendo 
bastante discutido nos últimos anos em todo mundo e várias medidas estão sendo adotadas para minimizar ou evitar essa complicação da doação de sangue, no entanto, é necessário conhecer o perfil da população atendida para estratificar quantitativamente a depleção de ferro nos doadores de sangue total.

Esse estudo visa a conhecer a população doadora de sangue total, alvo de depleção de ferro, para que seja possível sugerir estratégias pré ou pós doação com intuito de atender com segurança o doador. 


\subsection{Doação de sangue no mundo, no Brasil e Minas Gerais}

O sangue sempre esteve associado ao conceito da vida, na história da humanidade, inicialmente agregado a um sentimento místico e fantasioso. Os antigos egípcios banhavam-se nele para adquirir poderes e curar doenças, os aristocratas bebiam o sangue de jovens guerreiros para beneficiarem-se de suas qualidades, esse período faz parte da pré-história da hemoterapia. A evolução da hemoterapia foi marcada por erros e acertos que, no entanto, foram de extrema importância para que hoje a hemoterapia seja uma especialidade médica, fundamentada em dados científicos e não, como no passado, em tentativas empíricas. Como o sangue tornou-se um importante recurso terapêutico, atualmente é necessário que exista um estoque de sangue, seus componentes e derivados, qualitativa e quantitativamente adequados para atender a toda a população (CANÇADO et al., 2007; BORDIN, 2007).

Como ainda não foram desenvolvidos substitutos sintéticos adequados para o sangue, sua obtenção depende exclusivamente de doações (UBIALI, 2014). Para atender a esse cenário no mundo são coletados 112,5 milhões de bolsas de sangue por ano (WHO, 2019). No Brasil 3,3 milhões de pessoas doam sangue todos os anos, 1,65 \% da população, índice inferior ao preconizado pela Organização Mundial de Saúde (BRASIL, 2019). Em Minas Gerais, 287.444 bolsas de sangue foram coletadas pela Fundação Centro de Hematologia e Hemoterapia de Minas Gerais - Hemominas em 2018, o que equivale a $98 \%$ do sangue coletado no estado. Poços de Caldas, cidade de 160.000 mil habitantes, localizada no sul de Minas Gerais tem como principais rendas a exploração mineral de alumínio e produção de leite e derivados e café. A cidade dispõe de um posto de coleta da Fundação Hemominas, que em 2018 coletou 13.097 bolsas de sangue com intuito de atender as agências transfusionais conveniadas (FUNDAÇÃO HEMOMINAS, 2019). 


\subsection{Doador de Sangue}

Os doadores de sangue são classificados quanto à motivação, podendo ser, doador de sangue autólogo, que doa para si mesmo, respeitando as legislações vigentes; doador de sangue espontâneo, que doa motivado por um gesto altruísta sem qualquer tipo de vínculo ou benefício; e por fim, o doador de reposição, que doa para repor um sangue já utilizado por um paciente (UBIALI, 2014). Os doadores também são classificados em relação à periodicidade de doações em: doador de primeira vez, aquele que irá realizar a primeira doação na sua vida, o primodoador; doador de repetição, que doa mais de uma vez no período de 12 meses; e doador esporádico, ou não fidelizado, que doa em intervalos superiores a 12 meses (UBIALI, 2014; FUNDAÇÃO HEMOMINAS, 2019).

O intervalo mínimo entre as doações é variável, na maioria dos países é de 8 semanas, na Inglaterra, de 12 a 16 semanas. Foram propostos com o intuito de possibilitar a recuperação do ferro perdido na doação (POTTIGIESSER, 2008).

Levando em consideração a quantidade de doações realizadas por ano, a frequência de doações, e a necessidade mundial, em 2004, por exemplo, foram coletadas 15.244.000 bolsas de sangue nos Estados Unidos e esses números não foram suficientes para suprir a necessidade. Considerando que apenas $5 \%$ dos doadores elegíveis voluntários são doadores regulares no mundo, aumentar a frequência das doações para esses doadores pode aumentar a oferta de sangue, porém pode acarretar prejuízos à saúde do doador, como a sideropenia (POTTIGIESSER, 2008).

\subsection{Cuidados com o doador de sangue}

Com intuito de compartilhar conhecimento, foi fundada em 1935, a ISBT (Internacional Society of Blood Transfusion), para melhorar a segurança da transfusão de sangue em todo o mundo. Tais conhecimentos são disseminados principalmente por meio de periódicos como a Vox Sanguinis e Science Series (ISBT, 2019).

Em 1996, foi criado o SHOT no Reino Unido, que desde então tem coletado 
e analisado informações sobre eventos adversos e reações na transfusão de sangue de todas as organizações de saúde que estão envolvidas com hemoterapia, identificando riscos e problemas, e com isso produz recomendações para melhorar a segurança do doador e do paciente. As recomendações são colocadas no seu relatório anual, que é distribuído a todas as organizações relevantes do Reino Unido, sendo a hemovigilância um exercício contínuo (SHOT, 2019). Outro exemplo é o da $A A B B$, que desde 2006 é líder no estabelecimento do programa nacional de hemovigilância dos EUA com a implementação de um sistema para rastrear reações adversas e incidentes associados à coleta de sangue e à transfusão, tendo foco na segurança de doadores e pacientes (AABB, 2019).

No Brasil, em 2015, seguindo conceitos de vários sistemas internacionais já citados, foi publicado o Marco Conceitual e Operacional de Hemovigilância - Guia para Hemovigilância no Brasil, baseado principalmente nas diretrizes do ISBT (2008; 2011) com o propósito de definir as diretrizes com a inclusão da vigilância dos eventos adversos que podem ocorrer em todo o ciclo do sangue, da captação do doador ao ato transfusional (BRASIL, 2015). A Figura 1 representa a evolução da segurança transfusional no país e o desdobramento da hemovigilância dos doadores.

Figura 1 - Hemovigilância em hemoterapia.

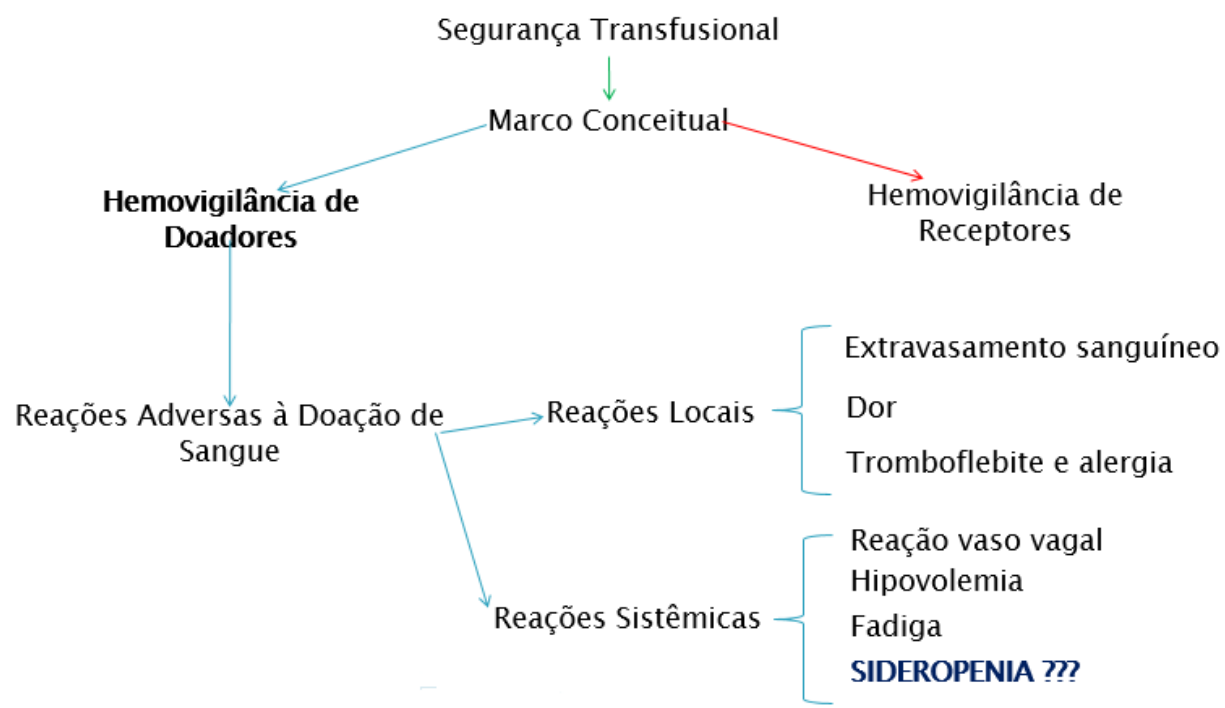

FONTE: A Autora (2019).

O Marco Conceitual traz um capítulo sobre a hemovigilância do doador, que pontua todos os eventos adversos imediatos que podem ocorrer antes, durante e 
após a doação de sangue. No entanto, não aborda uma das principais reações tardias ao doador, que é a sideropenia em doadores de repetição.

\subsubsection{Depleção de ferro no doador}

Durante várias décadas, o estudo da depleção de ferro no doador foi motivo de preocupação para as instituições coletoras de sangue. No entanto, apenas recentemente esse assunto ressurgiu em virtude de novas informações oriundas de estudos em grande escala comprovando a depleção de ferro nos doadores, além de evidências para os potenciais efeitos deletérios da depleção de ferro não anemica no individuo, e a mais importante, estudos controlados refinaram os benefícios da suplementação de ferro para o doador minimizando a depleção (KISS, 2018).

No trabalho de Gualandro et al (1999), das 1.252 mulheres candidatas à doação de sangue, 1,8\% foram recusadas por apresentarem anemia, sendo que, em $82,6 \%$ dos casos, o motivo de recusa estava relacionado à deficiência de ferro. Das candidatas aceitas para doação,19,8\% apresentavam deficiência de ferro.

Em 2012, Cable et al avaliaram os efeitos da doação de sangue nos doadores, através da avaliação da concentração de hemoglobina, da ferritina sérica e do receptor de transferrina e concluíram que há uma alta prevalência de depleção ferro em doadores de sangue frequentes. Observaram que a deficiência de ferro em doadores de sangue é endêmica, afetando em média $30 \%$ deles no mundo, com maior prevalência no sexo feminino (RIGAS,2014).

Foi realizado um estudo na República Democrática do Congo, tendo como principal objetivo estimar a prevalência de anemia ferropriva e depleção de ferro, avaliando hemoglobina e ferritina no momento da doação, entre dezembro de 2012 e agosto de 2013. Foram incluídos no estudo 386 doadoras, das quais 63,2\% tinham deficiência de ferro e 25,9\%, anemia ferropriva (LUKUSA, 2016).

No mesmo ano, na Austrália, foi desenvolvido um estudo que evidenciou a deficiência de ferro (ferritina $<15 \mathrm{ng} / \mathrm{mL}$ ) principalmente em mulheres doadoras. Para as mulheres que realizaram uma única doação em 12 meses houve um índice de $26,4 \%$ de depleção, para as que doaram mais de três vezes no mesmo período o índice foi de $32,5 \%$. E ainda, que $27 \%$ das doadoras que fizeram uma ou mais 
doações tinham um nível de ferritina inferior a $12 \mathrm{ng} / \mathrm{mL}$ (PASRICHA, 2017).

Mais recentemente, um estudo examinou a associação de doação de sangue e deficiência de ferro entre adolescentes e mulheres adultas nos Estados Unidos. A análise foi realizada utilizando dados do período de 1999 a 2010 pelo NHANES (National Health and Nutrition Examination Survey), que após analisar 2.419 adolescentes do sexo feminino, com idade entre 16 e 19 anos, das quais $10,7 \%$ doaram sangue e 7228 mulheres entre 20 e 49 anos, das quais $6,4 \%$ doaram sangue, os níveis séricos de ferritina foram menores nas adolescentes ( $p$ $<0,001)$ e mulheres ( $p<0,001)$ em comparação com os não doadores. Além disso, as doadoras tinham maior probabilidade de ter depósitos de ferro esgotados assim como de anemia ferropriva em comparação com mulheres não doadoras, levantando preocupações sobre as consequências a longo prazo da deficiência de ferro (PATEL,2019).

Recentemente, o estudo REDS III (Recipient Epidemiology and Donor Evaluation Study) avaliou estudantes do ensino médio dos EUA, com idade entre 16 a 18 anos, que contribuem com 10\% do suprimento de sangue do páis e concluiu que a doação de sangue pode ser um fator de risco para essa faixa etária, independentemente do número de doações. Nessa fase, a depleção de ferro é particularmente preocupante, pois pode influir negativamente no desenvolvimento físico ou neurocognitivo (SPENCER, 2019).

\subsection{Metabolismo do Ferro}

O ferro é um mineral essencial para os processos fisiológicos e para o metabolismo celular, e é encontrado em todas as células dos seres vivos. Participa ativamente da formação do eritrócito ao integrar-se ao grupo heme, juntamente com as globinas. O seu metabolismo está ligado a proteínas de transportes ou funcionais, que além de captar, transportar e armazenar o ferro também são responsáveis pela absorção do ferro solúvel pelo organismo. (FIGUEIREDO, 2013; NAOUM, 2010)

Um adulto do sexo masculino possui cerca de $35-45 \mathrm{mg}$ de ferro/ $\mathrm{kg}$ de peso, o que em mulheres em idade fértil é 30 a 40 \% menor (FIGUEIREDO, 2013), conforme quadro a seguir: 
Tabela 1 - Dados quantitativos sobre metabolismo do ferro

\begin{tabular}{lcc}
\hline & Homem $\mathbf{( 7 0 K g )}$ & Mulher $\mathbf{6 0} \mathbf{~ K g})$ \\
Total de ferro no organismo & $35-45 \mathrm{mg} / \mathrm{Kg}$ & $25-35 \mathrm{mg} / \mathrm{Kg}$ \\
Na forma de hemoglobina & $2,0 \mathrm{~g}$ & $1,7 \mathrm{~g}$ \\
Nos depósitos & $0,8-1,0 \mathrm{~g}$ & $0,3 \mathrm{~g}$ \\
Necessidades diárias & $0,5-1,0 \mathrm{mg} / \mathrm{dia}$ & $1,0-2,0 \mathrm{mg} / \mathrm{dia}$ \\
Perdido pela menstruação & & $15-30 \mathrm{mg} / \mathrm{mês}$ \\
Perdido na gravidez & $600 \mathrm{mg}$ \\
Perdido na lactação & & $0,5-1,0 \mathrm{mg} / \mathrm{dia}$ \\
& & \\
Quantidade absorvida na dieta & & \\
Para Produzir hemoglobina & $0,5-2 \mathrm{mg} / \mathrm{dia}$ & \\
Total ao nascimento & $20 \mathrm{mg} / \mathrm{dia}$ & \\
Sangue total & $250 \mathrm{mg}$ & \\
Concentrado de hemácias & $0,5 \mathrm{mg} / \mathrm{mL}$ & \\
\hline
\end{tabular}

FONTE: Adaptado FIGUEIREDO, 2013

A maior parte do ferro do organismo encontra-se ligado à molécula de hemoglobina, com função predominantemente de oxigenação. Sendo a hemoglobina o principal depósito de ferro no organismo, baixos níveis podem indicar carência de ferro. As mulheres necessitam do dobro de ferro diariamente em relação aos homens, em decorrência da menstruação, da amamentação e da gravidez. Outro local de armazenamento do ferro no organismo é a mioglobina, pigmento vermelho, com aproximadamente $300 \mathrm{mg}$ de ferro, que está presente nos músculos esqueléticos e cardíaco para liberação de oxigênio durante a contração (FIGUEIREDO, 2013; FERNANDES,2009).

O corpo não possui mecanismo ativo para excretar o ferro e as perdas ocorrerem através do suor, sangramento e no processo de descamação epiteliais, sendo necessário absorção de $1 \mathrm{mg}$ de ferro por dia (ERIKSSON et al., 2015).

Quando aumenta a demanda por ferro, sua absorção é aumentada no duodeno e os estoques liberados através dos macrófagos e outras células. Por outro lado, na sobrecarga secundária à transfusão, sua absorção é inibida (SILVA, 2015).

A deficiência de ferro não está relacionada apenas à anemia ferropriva (ERIKSSON et al., 2015), podendo também ser observada em algumas mulheres no período menstrual (NEWMAN, 2006), na síndrome das pernas inquietas (BIRGEGARD et al., 2010), necessidades fisiológicas aumentadas no crescimento 
e gestação, bem como em certos estados patológicos no sangramento gastrointestinal e nas parasitoses (BRINGHENTI, 2011).

\subsubsection{Absorção e armazenamento do ferro}

Para prover as necessidades do organismo, a recomendação diária de ferro na dieta é cerca de 10 a $15 \mathrm{mg}$, sendo absorvido pelo organismo de 0,5 a 2,0 mg/ dia, ou o equivalente às perdas (FERNANDES,2009).

Figura 2 Necessidade e perdas de ferro pelo organismo

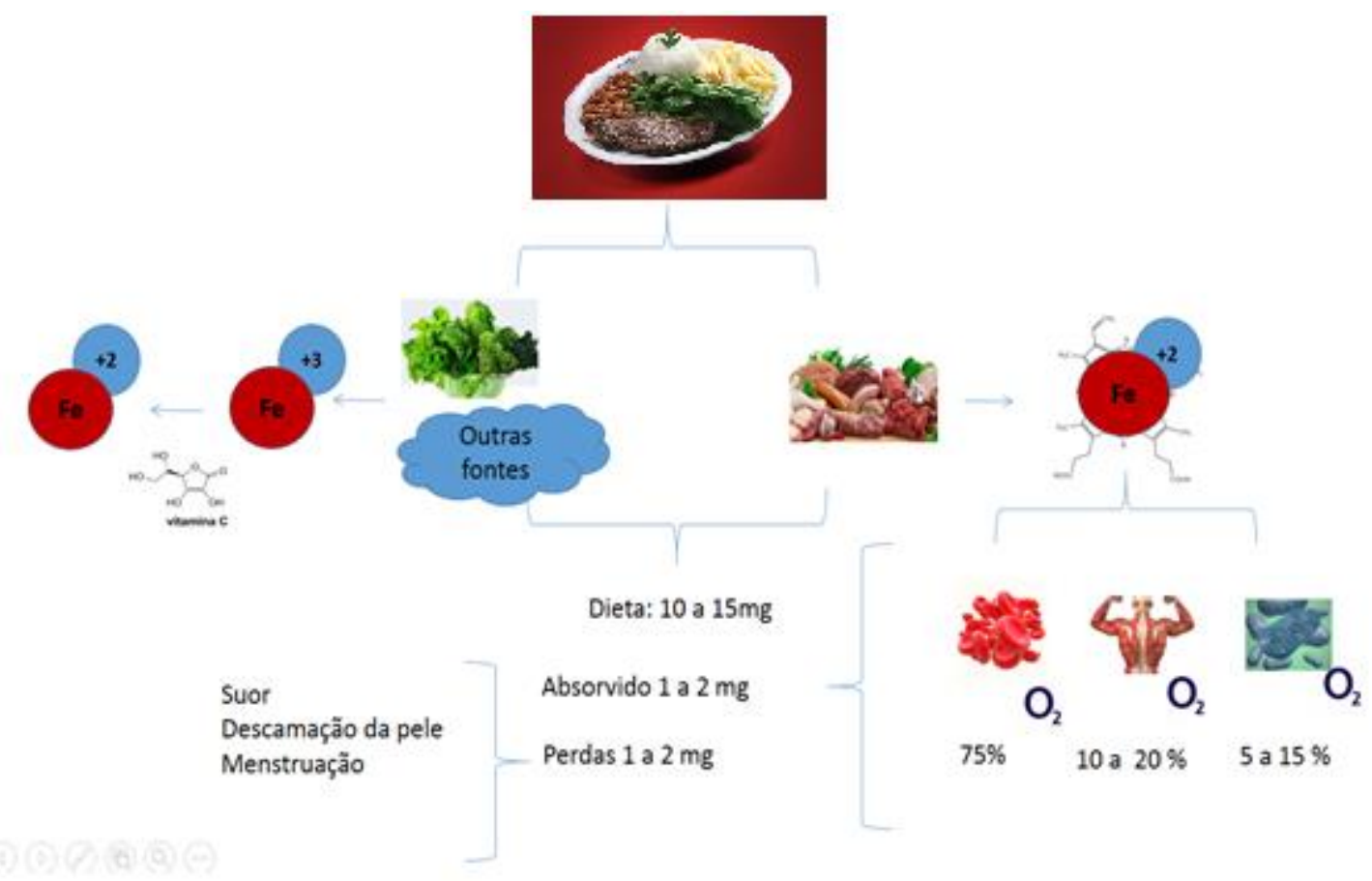

FONTE: A Autora (2019).

O ferro dietético pode ser do tipo heme ou não-heme. O ferro do tipo heme é encontrado nas hemoproteínas da hemoglobina e da mioglobina. Os alimentos com maior fonte de ferro heme são carnes de vaca e porco, frango e peixes. Alimentos ricos em vitamina $\mathrm{C}$ melhoram a absorção do ferro. No entanto, ácido fítico em grãos e leguminosas, polifenóis no chá e café, ou cálcio, presentes nos ovos e leite, a inibem (FISBERG,2008).

Outro importante mecanismo de homeostase é a reciclagem do ferro. Os macrófagos do baço e do fígado eliminam os eritrócitos senescentes, liberando o ferro da hemoglobina, sendo passível de ser reutilizado em novo ciclo de formação 
de hemoglobina. Este processo garante o um suprimento de ferro ao organismo, superior à contribuição da dieta (GROTTO, 2010).

Os sistemas regulatórios do ferro são essenciais para evitar a propagação dos radicais livres que alteram diversos sistemas fisiológicos, como a lipoperoxidação, desnaturação de proteínas, ataques a proteínas e ácidos nucléicos, estimulando inclusive a apoptose celular, resultando na lesão do organismo (SILVA, 2015).

\subsubsection{Ferritina}

Há mais de 70 anos a ferritina vem sendo estudada como a proteína de armazenamento do ferro. Em 1894, o alemão Oswald Schmiedeberg observou um componente rico em ferro no fígado de cavalo, e o chamou de ferritina. No entanto, só em 1937, o tcheco Vilém Laufberger, isolou a ferritina do baço do cavalo através da cristalização com sais de cadmio (ALKHATEEB, 2013).

A apoferritina, proteína esférica com peso molecular de aproximadamente 450.000 daltons e o ferro, constituem a ferritina, que é capaz de incorporar até 4.500 átomos de ferro. São compostas de 24 subunidades, em dois tipos: ferritina $\mathrm{H}$ (de alto peso molecular ou Heavy ou Heart), massa molecular de $21 \mathrm{kDa}$, codificado por gene no cromossomo 11q, possui atividade enzimática e pode oxidar ferro ferroso em ferro férrico, sendo útil na regulação do ferro no organismo, com a desintoxicação rápida e o transporte intracelular; ferritina $L$ (de baixo peso molecular ou Light ou Liver), com massa molecular de 19 kDa, codificado por gene no cromossomo 19q, não tem atividade enzimática e, portanto, não contribui para a oxidação e absorção. No entanto, estão em maior número e são a principal forma de armazenamento do ferro (BRITTENHAM, 2000; ALKHATEEB, 2013).

A ferritina sérica é uma proteína de fase aguda, descrita pela primeira vez em 1948. É a forma encontrada na circulação, estará em níveis menores em pacientes com anemia ferropriva ou após flebotomias e em maiores níveis em pacientes com hemocromatose, desta forma é um bom indicador para avaliação dos níveis de ferro no organismo (ALKHATEEB, 2013). 


\subsection{Deficiência de ferro}

A deficiência de ferro no organismo ocorre quando há redução do ferro corpóreo total, com diminuição ou depleção total dos estoques. O ferro ocupa diversos compartimentos que didaticamente são divididos em: estoque, transporte e funcional, e são afetados sequencialmente à medida que o déficit de ferro corpóreo progride. A figura 3 mostra os estágios de depleção do ferro de acordo com o compartimento afetado (GROTTO,2010).

Figura 3 - Fases de depleção de ferro

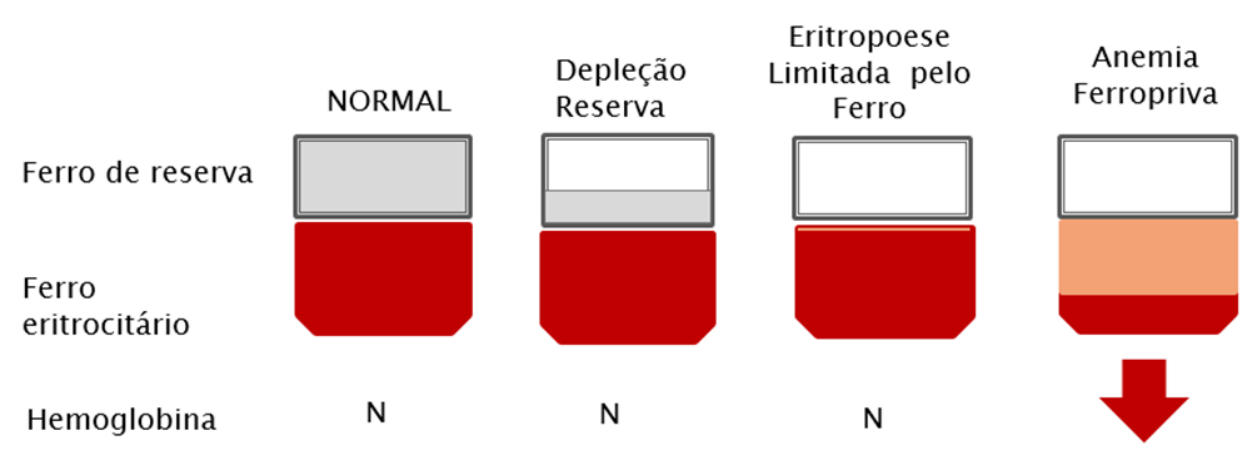

FONTE: A Autora (2019).

O primeiro estágio da deficiência de ferro é a depleção de ferro, ou seja, deficiência latente de ferro, com queda da reserva de ferro no organismo, o ferrro se torna ausente no compartimento de armazenamento, mas o compartimento funcional não é afetado. Quando há um esgotamento nas reservas de ferro, a quantidade do mineral no compartimento de transporte começa a diminuir, caracterizando a segunda fase de depleção, a fase de eritropoiese deficiente em ferro foi alcançada, isto é, o suprimento de ferro para a medula eritropoiética é insuficiente para a eritropoiese, porém os níveis de $\mathrm{Hb}$ ainda são normais, condição definida como deficiência de ferro subclínica. O terceiro e último estágio ocorre quando o compartimento funcional é finalmente afetado e o suprimento de ferro não é mais suficiente para produzir uma quantidade normal de $\mathrm{Hb}$, a anemia por deficiência de ferro torna-se aparente. Portanto, os níveis de $\mathrm{Hb}$ são baixos apenas nessa fase avançada da deficiência de ferro (BAART,2013). Nesse caso, doadores de sangue, que apresentam níveis de $\mathrm{Hb}$ normais, podem apresentar 
depleção de ferro (FINCH,1977) ou em casos mais avançados, eritropoese deficiente em ferro (SKIKNE, 1984).

Há vários exames que podem identificar a depleção de ferro no organismo, frequentemente é indicado o nível sérico de ferritina (FINCH, 1977).

Embora estudos realizados com doadores de sangue não tenham identificado efeitos prejudiciais ao bem-estar, a deficiência de ferro, mesmo sem anemia, poderá estar associada à fadiga sintomática, redução de capacidade de execuação de atividades físicas e diminuição no desempenho cognitivo (PASRICHA,2017).

Diante do exposto, esse estudo teve como objetivo analisar em uma população doadora de sangue total a relação entre níveis hematimétricos e estoque de ferro, através da ferritina sérica e as características principais de maiores prevalências. 


\section{OBJETIVOS}

\subsection{Geral}

Investigar, prospectivamente, a prevalência de sideropenia, por meio da dosagem de ferritina sérica, nos doadores de sangue da unidade da Fundação Hemominas de Poços de Caldas.

\subsection{Específicos}

- Determinar e correlacionar a ferritina sérica, a hematimetria e o histórico de doações.

- Explorar causas de depleção de ferro que não a doação de sangue.

- Comparar as características dos doadores sem anemia e com ferritina normal com os doadores sem anemia e com ferritina baixa.

- Comparar a prevalência de deficiência de ferro em doadores do sexo masculino e do feminino. 


\section{MATERIAL E MÉTODOS}

Trata-se de estudo transversal e prospectivo envolvendo doadores de sangue que doaram no período de 18/01/2019 a 02/03/2019, na unidade da Fundação Hemominas em Poços de Caldas - MG, segundo os critérios de inclusão e exclusão.

\subsection{Critérios de Inclusão}

- Primodoadores de sangue ou doadores de repetição, de ambos os sexos, com idade entre 18 e 60 anos, aptos para a doação de sangue de acordo com a Portaria de Consolidação ํㅜ 5, de 28 de setembro de 2017.

- Os doadores de repetição foram aceitos se tiveram doação (ões) prévia (s) nas unidades da Fundação Hemominas ou tiveram realizado doação (ões) de sangue em outras instituições até dois anos antes.

- Não foram incluidos os candidatos que não puderam doar sangue por qualquer motivo.

\subsection{Critérios de Exclusão}

- Doadores que tiveram anemia, mesmo que tratada, nos últimos dois anos.

- Doadores que realizaram doação de sangue em outras instituições nos últimos dois anos.

- Doadores que não aceitarem participar da pesquisa.

- Dosagem inconclusiva da ferritina.

\subsection{Variáveis}

Além das respostas obtidas na triagem clínica usual dos doadores, de acordo com a legislação vigente, para o doador que aceitou participar do estudo, foi entregue o termo de consentimento livre e esclarecido (APÊNDICE A), e foi aplicado um questionário estruturado e específico com objetivo de avaliar possíveis variáveis capazes de interferir na análise pretendida (APÊNDICE B): 
- Peso e estatura do doador para cálculo de IMC, que é calculado com a fórmula peso / altura ${ }^{2}$.

- Histórico de doações e interrupções de doações por anemia (doadores que foram impossibilidados de doar anteriormente na triagem hematológica por apresentarem níveis hematimétricos abaixo do preconizado pela legislação vigente).

- Alimentação: verificada a frequência de consumo de alguns alimentos, sendo parametrizada em 1 a 2 refeições, 3 a 4 refeições, 5 a 9 refeições, 10 a 14 refeições, mais que 14 refeições e não consome o alimento. Sobre o tipo de carne consumida, foram apresentadas as opções: vaca, porco, frango ou peixe e arguida a frequência. Quanto ao consumo de leite e derivados, além da frequência foram observados os horários de ingestão: no café da manhã, após as refeições, o dia todo, a noite ou não consome. Também foi arguido ao doador se é vegetariano ou vegano e, caso positivo, a quanto tempo. Quanto ao consumo de verduras verdes escuras, foi exemplicado ao doador as verduras desse grupo mais frequentes na região (couve, brócolis, agrião, rúcula e ora pro nobis) e arguida a frequência.

- Quanto ao uso de suplementos, verificou-se se o doador consome ou não e, caso positivo, a quanto tempo.

- Para ambos os sexos se perguntou sobre o consumo de bebida alcoólica e a frequência (parâmetros aplicados: diariamente, eventualmente, raramente ou não bebe). Se fuma cigarro de papel, se sim quantos ao dia e se não, se é ex-fumante e há quanto tempo. Exclusivamente às mulheres, foi arguido sobre menstruação (se menstrua, duração do ciclo: $\leq 3$, 4 a 7 ou $>7$ dias, quantidade média de absorventes $\leq 2,3$ a 4 ou $>4$ unidades e a quantidade de ciclos por mês) e histórico gestacional (se já engravidou e, se sim, quantas vezes).

- Para hipermenorréia foi considerado mais de 4 dias de fluxo menstrual associada com o uso de mais de 4 absorventes por dia.

- Quanto à história prévia de anemia, verificado com todos doadores se sim ou não e, em caso positivo, se foi tratado com ferro.

- Outras cormobidades relacioanadas com a depleção de ferro foram perguntadas ao doador: uso de medicamentos (inibidores de bomba); sangramento no tubo digestivo: crônicos ou agudos; síndrome de má 
absorção intestinal; doença celíaca; epistaxe; doenças descamativas da pele; doenças respiratórias.

\subsection{Tamanho amostral}

Para o número mínimo de sujeitos, foi realizado cálculo amostral no software GPower (versão 3.1.9.2) com correção para populações finitas (MIOT, 2011) e sendo adotado um poder de $80 \%$ e $\alpha=0,05$ (ROSA, 2016). Tendo por base o número de 1000 doações de sangue realizadas em um mês, o número mínimo estimado foi de 278 doadores.

\subsection{Métodos Laboratoriais}

\section{Ferritina}

A dosagem de ferritina foi padronizada utilizando Kit da Bioclin (Referência K081) onde, a determinação do ponto final da concentração da ferritina será realizada através de medição fotométrica da reação antígeno-anticorpo, entre partículas de látex marcadas com anticorpo anti-ferritina e ferritina presente na amostra. O padrão de normalidade foi para homens o intervalo de 30 a $220 \mathrm{ng} / \mathrm{mL}$, e para mulheres entre 20 a $110 \mathrm{ng} / \mathrm{mL}$.

A ferritina sérica apresenta de acordo com cada fabricante o intervalo de normalidade que se estende de 30 a $330 \mathrm{ng} / \mathrm{dL}$. Para fins didáticos foram considerados três intervalos: maior chance de depleção de ferro com ferritina menor que 30 , os doadores entre 30 e $60 \mathrm{ng} / \mathrm{dL}$ e doadores com mais de $60 \mathrm{ng} / \mathrm{dL}$ de ferritina sérica.

\section{Hemoglobina}

A legislação vigente determina que doadores do sexo feminino com hemoglobina $(\mathrm{Hb})$ maior ou igual a $12,5 \mathrm{~g} / \mathrm{dL}$ podem realizar doação de sangue e os homens devem apresentar $13 \mathrm{~g} / \mathrm{dL}$. Para fins de correlação com a ferritina, esse estudo considerou $\mathrm{Hb}$ de $13 \mathrm{~g} / \mathrm{dL}$ para mulheres e 13,5 g/dL para homens, pois valores menores que os preconizados pela legislação não foram selecionados para participar do estudo. 


\subsection{Análise dos Dados}

Os resultados foram plotados no Excel e posteriormente processados com a ajuda do software SPSS (Statistical Package for Social Sciences, versão 23). Neste estudo, os dados não apresentaram distribuição paramétrica $(p<0,05)$ segundo resultado do Teste de Normalidade de Shapiro-Wilk (RAZALI et al., 2011). A estatística descritiva foi realizada (GALHARDI et al., 2018) utilizando os dados dos questionários, e as variáveis foram correlacionadas através dos testes de MannWhitney e Qui-quadrado (X2), com nível de significância de 5\% (DAWSON, 2003).

\subsection{Aspectos Éticos}

O presente projeto de pesquisa foi submetido à apreciação do Comitê de Ética da Fundação Hemominas, CAAE: 00914918.5.0000.5118, de acordo com as exigências da Resolução 466/2012, Norma Operacional CNS/MS 001/2013 e suas complementares, sendo que a coleta de dados só foi iniciada depois de obtida essa aprovação. Os aspectos éticos, quanto ao sigilo, privacidade e todos os demais previstos na referida Resolução do CNS/MS foram respeitadas. 
No período de 18/01/2019 a 2/03/2019, foram utilizados neste trabalho após seleção segundo os critérios de inclusão e exclusão, o total de 1.002 doadores. Destes, $599(59,8 \%)$ foram do sexo masculino e $403(40,2 \%)$ do sexo feminino. No entanto foram excluídos 16 doadores, 11 mulheres e 5 homens, cujas amostras de ferritina foram inconclusivas devido à amostra lipêmica ou hemolisada.

$\mathrm{Na}$ Tabela 2 estão representadas as frequências observadas no estudo quando correlacionamos o sexo dos participantes, concentração de ferritina e concentração de hemoglobina. Não foram observadas diferenças significantes entres as variáveis $(p>0,05)$.

Tabela 2 - Relação entre sexo, concentração de ferritina ( $\mathrm{ng} / \mathrm{mL})$, hemoglobina $(\mathrm{Hb})$ e número de doaçöes

\begin{tabular}{|c|c|c|c|c|c|}
\hline & \multicolumn{5}{|c|}{ Mulheres (número de doações) } \\
\hline & 1 & 2 a 6 & Mais de 6 & Total & Estatistica \\
\hline $\begin{array}{l}\text { Ferritina }<30 \mathrm{ng} / \mathrm{mL} \\
\mathrm{Hb} \leq 13(\mathrm{~g} / \mathrm{dL})^{\star}\end{array}$ & $\begin{array}{c}27 \\
4\end{array}$ & $\begin{array}{l}60 \\
12\end{array}$ & $\begin{array}{c}21 \\
6\end{array}$ & $\begin{array}{c}108 \\
22\end{array}$ & $p>0,05$ \\
\hline $\begin{array}{l}\text { Ferritina entre } 30 \text { e } 60 \mathrm{ng} / \mathrm{mL} \\
\mathrm{Hb} \leq 13(\mathrm{~g} / \mathrm{dL})^{*}\end{array}$ & $\begin{array}{c}33 \\
4\end{array}$ & $\begin{array}{l}79 \\
12\end{array}$ & $\begin{array}{c}15 \\
3\end{array}$ & $\begin{array}{c}124 \\
19\end{array}$ & $p>0,05$ \\
\hline \multirow[t]{3}{*}{$\begin{array}{l}\text { Ferritina }>60 \mathrm{ng} / \mathrm{mL} \\
\mathrm{Hb} \leq 13(\mathrm{~g} / \mathrm{dL})^{*}\end{array}$} & $\begin{array}{c}71 \\
8\end{array}$ & $\begin{array}{l}74 \\
11\end{array}$ & $\begin{array}{c}15 \\
3\end{array}$ & $\begin{array}{c}160 \\
22\end{array}$ & $p>0,05$ \\
\hline & \multicolumn{5}{|c|}{ Homens (número de doações) } \\
\hline & 1 & 2 a 8 & Mais de 8 & Total & Estatistica \\
\hline $\begin{array}{l}\text { Ferritina }<30 \mathrm{ng} / \mathrm{mL} \\
\mathrm{Hb} \leq 13,5(\mathrm{~g} / \mathrm{dL})^{*}\end{array}$ & $\begin{array}{l}9 \\
1\end{array}$ & $\begin{array}{c}31 \\
1\end{array}$ & $\begin{array}{c}15 \\
2\end{array}$ & $\begin{array}{c}55 \\
4\end{array}$ & $p>0,05$ \\
\hline $\begin{array}{l}\text { Ferritina entre } 30 \text { e } 60 \mathrm{ng} / \mathrm{mL} \\
\mathrm{Hb} \leq 13,5(\mathrm{~g} / \mathrm{dL})^{*}\end{array}$ & $\begin{array}{c}15 \\
0\end{array}$ & $\begin{array}{c}74 \\
1\end{array}$ & $\begin{array}{c}22 \\
1\end{array}$ & $\begin{array}{c}111 \\
2\end{array}$ & $p>0,05$ \\
\hline $\begin{array}{l}\text { Ferritina }>60 \mathrm{ng} / \mathrm{mL} \\
\mathrm{Hb} \leq 13,5(\mathrm{~g} / \mathrm{dL})^{*}\end{array}$ & $\begin{array}{c}113 \\
2\end{array}$ & $\begin{array}{c}251 \\
6\end{array}$ & $\begin{array}{c}64 \\
3\end{array}$ & $\begin{array}{c}428 \\
11\end{array}$ & $p>0,05$ \\
\hline
\end{tabular}

FONTE: A Autora, 2019.

No gráfico 1 há representação das frequências das participantes do sexo feminino em relação a quantidade de doações e a concentração de ferritina encontrada. 
Gráfico 1 - Representação das frequências das participantes do estudo do sexo feminino de acordo com a quantidade de doações e a concentração de ferritina encontrada.

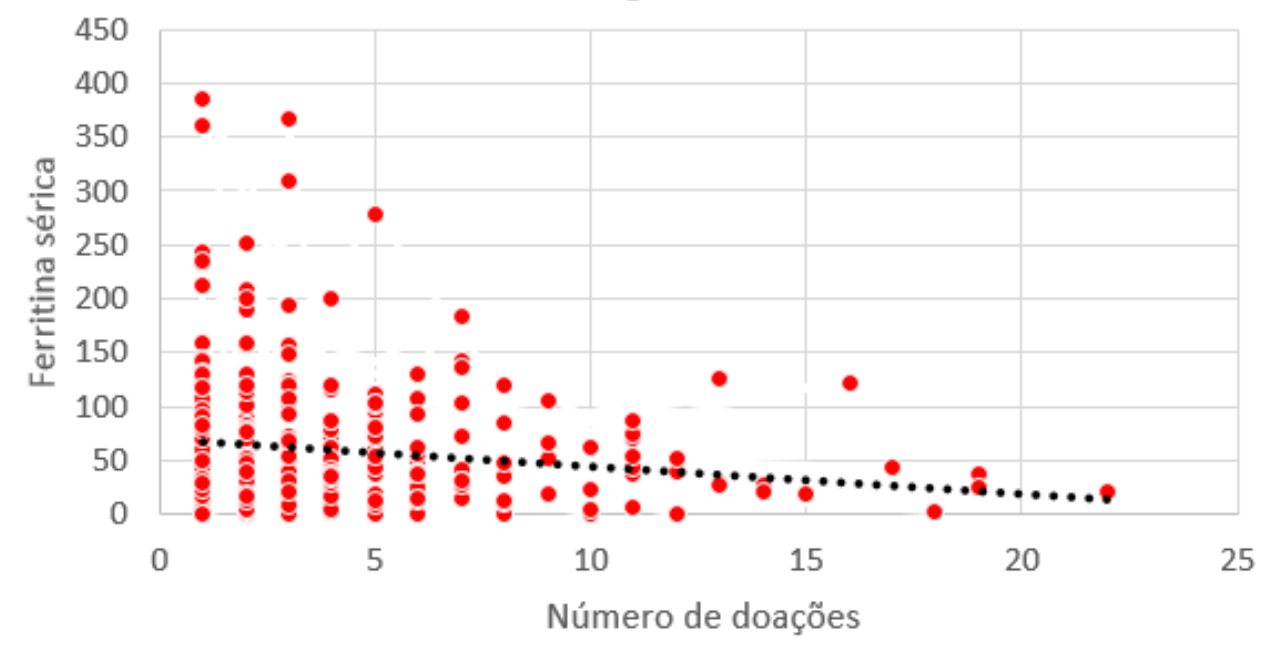

- FERRITINA $\quad \cdots \cdots$ Tendência de ferritina sérica

FONTE: A Autora, 2019.

No gráfico 2 há representação das frequências dos participantes do sexo masculino em relação a quantidade de doações e a concentração de ferritina encontrada.

Gráfico 2 - Representação das frequências dos participantes do estudo do sexo masculino de acordo com a quantidade de doações e a concentração de ferritina encontrada

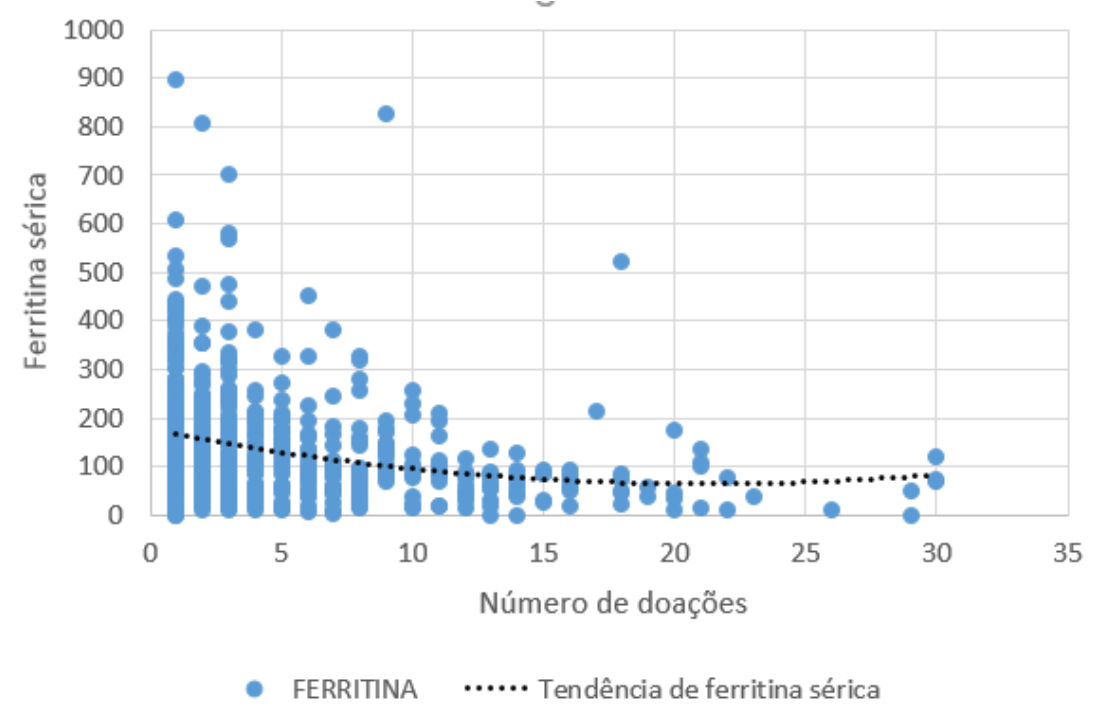

FONTE: A Autora, 2019. 
$\mathrm{Na}$ Tabela 3, não foram observadas diferenças significantes em relação a concentração de hemoglobina, se foi a primeira doação, ou se já interrompeu doação por anemia, com $p>0,05$. Foi encontrada diferença significante entre idade, onde as pessoas mais velhas apresentavam maior concentração de ferritina em relação as pessoas com ferritina entre 30 e $60 \mathrm{ng} / \mathrm{mL}$. Estes grupos não apresentaram diferença entre o grupo com ferritina $<30 \mathrm{ng} / \mathrm{dL}$.

Tabela 3 - Comparação das participantes femininas de acordo com seu histórico transfusional

\begin{tabular}{|c|c|c|c|c|}
\hline & Ferritina $<30 \mathrm{ng} / \mathrm{mL}$ & $\begin{array}{c}\text { Ferritina de } 30 \text { a } \\
60 \mathrm{ng} / \mathrm{mL}\end{array}$ & $\begin{array}{l}\text { Ferritina } \\
>60 \mathrm{ng} / \mathrm{mL}\end{array}$ & Estatística \\
\hline Idade (anos) & $31(27-39)^{\mathrm{ab}}$ & $30,5(23-39,7)^{a}$ & $36(26-45)^{b}$ & $p<0,01$ \\
\hline $\begin{array}{l}\text { Hemoglobina* } \\
\text { (mg/dL) }\end{array}$ & $13,8(13,3-14,4)^{a}$ & $14(13,3-14,7)^{\mathrm{a}}$ & $\begin{array}{c}14(13,4- \\
14,7)^{\mathrm{a}}\end{array}$ & $p>0,05$ \\
\hline Ferritina $(\mathrm{ng} / \mathrm{mL})$ & $17,5(9,2-23)^{a}$ & $44(37-51)^{b}$ & $95(73-119,8)^{c}$ & $p<0,0001$ \\
\hline $\begin{array}{l}\text { Primeira Doação } \\
\text { Sim } \\
\text { Não }\end{array}$ & $\begin{array}{l}22(20,4 \%) \\
86(79,6 \%)\end{array}$ & $\begin{array}{c}24(19,4 \%) \\
100(80,6 \%)\end{array}$ & $\begin{array}{c}47(19,4 \%) \\
113(70,6 \%)\end{array}$ & $p>0,05$ \\
\hline $\begin{array}{l}\text { Já doou outra } \\
\text { instituição } \\
\text { Sim } \\
\text { Não }\end{array}$ & $\begin{array}{l}16(18,6 \%) \\
70(81,4 \%)\end{array}$ & $\begin{array}{l}20(20 \%) \\
80(80 \%)\end{array}$ & $\begin{array}{l}34(30,1 \%) \\
79(69,9 \%)\end{array}$ & $p>0,05$ \\
\hline $\begin{array}{l}\text { Número de } \\
\text { doações } \\
\text { Uma } \\
\text { Duas a seis } \\
\text { Seis ou mais }\end{array}$ & $\begin{array}{l}22(20,4 \%) \\
52(48,1 \%) \\
34(31,5 \%)\end{array}$ & $\begin{array}{c}20(20 \%) \\
78(62,9 \%) \\
26(17,1 \%)\end{array}$ & $\begin{array}{l}71(44,4 \%) \\
70(43,7 \%) \\
19(11,9 \%)\end{array}$ & $P<0,001$ \\
\hline $\begin{array}{l}\text { Interrompeu por } \\
\text { anemia } \\
\text { Sim } \\
\text { Não }\end{array}$ & $\begin{array}{c}4(4,6 \%) \\
82(95,4 \%)\end{array}$ & $\begin{array}{c}7(7 \%) \\
93(93 \%) \\
\end{array}$ & $\begin{array}{c}7(6,2 \%) \\
106(93,8 \%)\end{array}$ & $p>0,05$ \\
\hline
\end{tabular}

FONTE: A Autora, 2019. 
$\mathrm{Na}$ Tabela 4, foram feitas as correlações entre os homens segundo a mesma divisão aplicada para as mulheres. Não foram observadas diferenças significantes.

Tabela 4 - Comparação dos participantes masculinos de acordo com seu histórico transfusional

\begin{tabular}{|c|c|c|c|c|}
\hline & $\begin{array}{c}\text { Ferritina } \\
<30 \mathrm{ng} / \mathrm{mL}\end{array}$ & $\begin{array}{c}\text { Ferritina de } 30 \\
\text { a } 60 \mathrm{ng} / \mathrm{mL}\end{array}$ & $\begin{array}{c}\text { Ferritina } \\
>60 \mathrm{ng} / \mathrm{mL}\end{array}$ & Estatística \\
\hline Idade (anos) & $33(25-43)^{a}$ & $34(26-41)^{\mathrm{a}}$ & $35(27-45)^{\mathrm{a}}$ & $p>0,05$ \\
\hline Hemoglobina* (mg/dL) & $15,3(14,8-16)^{a}$ & $\begin{array}{c}15,4(14- \\
16,6)^{\mathrm{a}}\end{array}$ & $15,7(15-16,5)^{\mathrm{a}}$ & $p>0,05$ \\
\hline Ferritina $(\mathrm{ng} / \mathrm{mL})$ & $18(13-24)^{\mathrm{a}}$ & $45(37-53)^{b}$ & $142(95-211)^{c}$ & $p<0,0001$ \\
\hline $\begin{array}{l}\text { Primeira Doação } \\
\text { Sim } \\
\text { Não }\end{array}$ & $\begin{array}{c}7(12,7 \%) \\
48(87,3 \%)\end{array}$ & $\begin{array}{c}11(9,9 \%) \\
100(90,1 \%)\end{array}$ & $\begin{array}{c}79(18,5 \%) \\
349(81,5 \%)\end{array}$ & $p>0,05$ \\
\hline $\begin{array}{l}\text { Já doou outra } \\
\text { instituição } \\
\text { Sim } \\
\text { Não }\end{array}$ & $\begin{array}{l}13(27,1 \%) \\
35(72,9 \%)\end{array}$ & $\begin{array}{l}24(24,0 \%) \\
76(76,0 \%)\end{array}$ & $\begin{array}{l}110(31,5 \%) \\
239(68,5 \%)\end{array}$ & $p>0,05$ \\
\hline $\begin{array}{l}\text { Número de doações } \\
\text { Uma } \\
\text { Duas a oito } \\
\text { Oito ou mais }\end{array}$ & $\begin{array}{c}9(16,3 \%) \\
31(56,3 \%) \\
15(27,4 \%)\end{array}$ & $\begin{array}{l}16(14,4 \%) \\
74(66,6 \%) \\
21(19,0 \%)\end{array}$ & $\begin{array}{l}117(27,3 \%) \\
247(57,7 \%) \\
64(15,0 \%)\end{array}$ & $p>0,05$ \\
\hline $\begin{array}{l}\text { Interrompeu por } \\
\text { anemia } \\
\text { Sim } \\
\text { Não }\end{array}$ & $\begin{array}{c}1(2,1 \%) \\
47(97,9 \%) \\
\end{array}$ & $\begin{array}{c}1(1,0 \%) \\
99(99,0 \%)\end{array}$ & $\begin{array}{c}4(1,1 \%) \\
345(98,9 \%)\end{array}$ & $p>0,05$ \\
\hline
\end{tabular}

FONTE: A Autora, 2019.

$\mathrm{Na}$ tabela 5, os mesmos grupos foram correlacionadas segundo sua alimentação, e foi observada correlação entre a frequência do consumo de carne em relação as diferentes concentrações de ferritinas $(p<0,0001)$. Já no consumo de carne, tipo de carne, consumo de leite e derivados, consumo de verduras escuras, bem como ser vegano ou vegetariano, não apresentaram diferença significante entre os grupos, com $p>0,05$. 
Tabela 5 - Comparação do grupo das mulheres de acordo com sua alimentação

\begin{tabular}{|c|c|c|c|c|}
\hline & $\begin{array}{c}\text { Ferritina } \\
<30 \mathrm{ng} / \mathrm{mL}\end{array}$ & $\begin{array}{c}\text { Ferritina de } \\
30 \text { a } 60 \mathrm{ng} / \mathrm{mL}\end{array}$ & $\begin{array}{c}\text { Ferritina } \\
>60 \mathrm{ng} / \mathrm{mL}\end{array}$ & Estatística \\
\hline $\begin{array}{l}\text { Consumo frequência de carne } \\
1 \text { a } 2 \text { refeições } \\
3 \text { a } 4 \text { refeições } \\
5 \text { a } 9 \text { refeições } \\
10 \text { a } 14 \text { refeições } \\
\text { > } 14 \text { refeições } \\
\text { Não come carne }\end{array}$ & $\begin{array}{c}9(8,3 \%) \\
22(20,4 \%) \\
51(47,2 \%) \\
23(21,3 \%) \\
0(0 \%) \\
3(2,8 \%)\end{array}$ & $\begin{array}{c}25(20,2 \%) \\
24(19,4 \%) \\
51(41,1 \%) \\
13(10,5 \%) \\
1(0,8 \%) \\
5(4,0 \%)\end{array}$ & $\begin{array}{c}16(10,0 \%) \\
22(13,8 \%) \\
72(45,0 \%) \\
46(28,8 \%) \\
2(1,3 \%) \\
2(1,3 \%)\end{array}$ & $p<0,0001$ \\
\hline $\begin{array}{l}\text { Tipo de carne que mais come } \\
\text { Frango } \\
\text { Peixe } \\
\text { Porco } \\
\text { Vaca }\end{array}$ & $\begin{array}{c}34(31,5 \%) \\
3(2,8 \%) \\
16(14,8 \%) \\
52(48,1 \%)\end{array}$ & $\begin{array}{c}55(44,4 \%) \\
5(4,0 \%) \\
12(9,7 \%) \\
47(37,9 \%)\end{array}$ & $\begin{array}{c}58(36,7 \%) \\
3(1,9 \%) \\
19(12,0 \%) \\
78(49,4 \%)\end{array}$ & $p>0,05$ \\
\hline $\begin{array}{l}\text { Frequência consumo de leite e } \\
\text { derivados na semana } \\
\qquad \text { a } 2 \text { vezes } \\
3 \text { a } 4 \text { vezes } \\
5 \text { a } 9 \text { vezes } \\
10 \text { a } 14 \text { vezes } \\
\text { > } 14 \text { vezes } \\
\text { Não consome }\end{array}$ & $\begin{array}{c}19(17,6 \%) \\
22(20,4 \%) \\
42(38,9 \%) \\
20(18,5 \%) \\
0(0 \%) \\
5(4,6 \%)\end{array}$ & $\begin{array}{c}25(20,2 \%) \\
24(19,4 \%) \\
51(41,1 \%) \\
13(10,5 \%) \\
1(0,8 \%) \\
10(8,1 \%)\end{array}$ & $\begin{array}{c}27(17,1 \%) \\
34(21,5 \%) \\
58(36,7 \%) \\
25(15,8 \%) \\
0(0 \%) \\
16(10,1 \%)\end{array}$ & $p>0,05$ \\
\hline $\begin{array}{l}\text { Vegano } \\
\text { Sim } \\
\text { Não }\end{array}$ & $\begin{array}{c}0(0 \%) \\
108(100 \%)\end{array}$ & $\begin{array}{c}1(0,8 \%) \\
123(99,2 \%)\end{array}$ & $\begin{array}{c}0(0 \%) \\
160(100 \%)\end{array}$ & $p>0,05$ \\
\hline $\begin{array}{l}\text { Vegetariano } \\
\text { Sim } \\
\text { Não }\end{array}$ & $\begin{array}{c}3(2,8 \%) \\
105(97,2 \%)\end{array}$ & $\begin{array}{c}3(2,4 \%) \\
121(97,6 \%)\end{array}$ & $\begin{array}{c}2(1,3 \%) \\
158(98,8 \%)\end{array}$ & $p>0,05$ \\
\hline $\begin{array}{l}\text { Consumo verduras escuras } \\
\text { Sim } \\
\text { Não }\end{array}$ & $\begin{array}{l}97(89,8 \%) \\
11(10,2 \%) \\
\end{array}$ & $\begin{array}{c}117(94,4 \%) \\
7(5,6 \%) \\
\end{array}$ & $\begin{array}{c}155(96,9 \%) \\
5(3,1 \%) \\
\end{array}$ & $p>0,05$ \\
\hline
\end{tabular}

Dados apresentados como frequências observadas (porcentagem). Dados analisados através do teste de qui-quadrado. Diferenças significantes entre os grupos, foram consideradas com $p<0,05$.

FONTE: A Autora, 2019.

Gráfico 3 - Representação das frequências dos participantes do estudo do sexo feminino de acordo consumo de carne, o tipo, número de porções e média de doações.

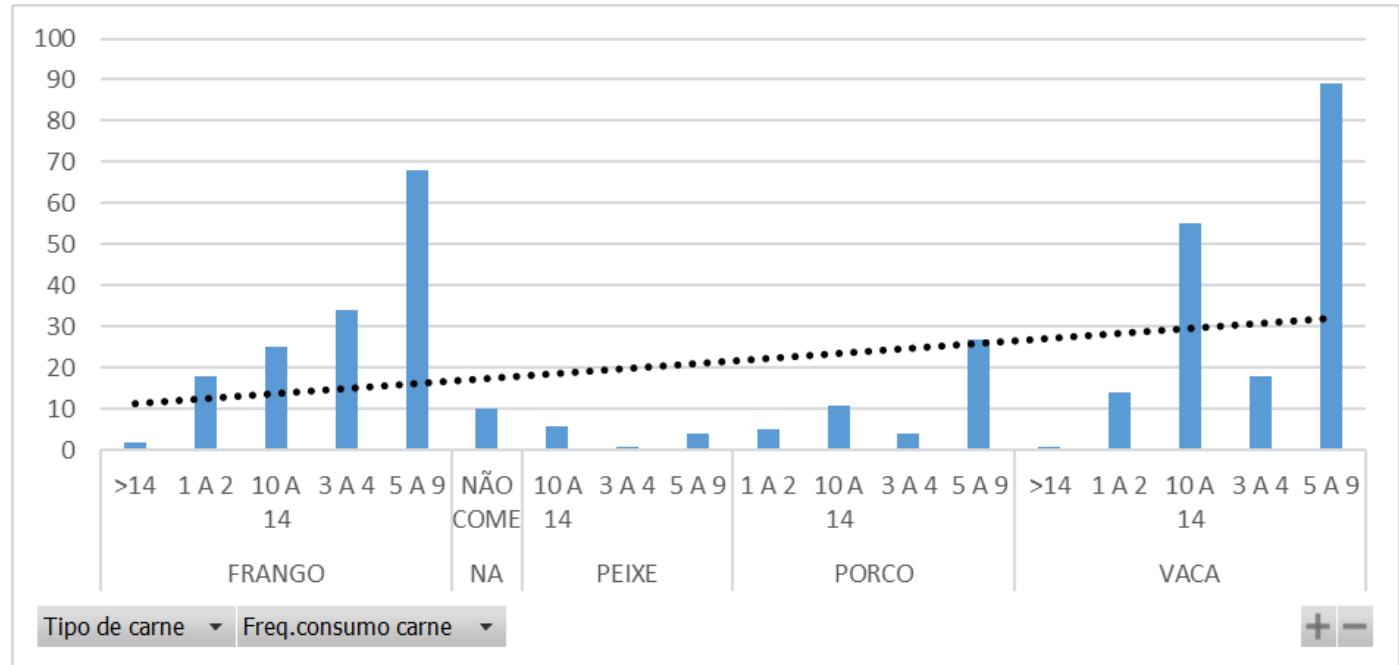

FONTE: A Autora, 2019. 
$\mathrm{Na}$ tabela 6, os homens foram analisados de acordo com sua ingesta alimentar, e não foram observadas correlações entre o consumo de carne, tipo de carne, consumo de leite e derivados, consumo de verduras escuras, bem como ser vegano ou vegetariano, com $\mathrm{p}>0,05$.

Tabela 6 - Comparação do grupo dos homens de acordo com sua alimentação

\begin{tabular}{|c|c|c|c|c|}
\hline & $\begin{array}{c}\text { Ferritina } \\
<30 \mathrm{ng} / \mathrm{mL}\end{array}$ & $\begin{array}{c}\text { Ferritina de } \\
30 \text { a } 60 \mathrm{ng} / \mathrm{mL}\end{array}$ & $\begin{array}{c}\text { Ferritina } \\
>60 \mathrm{ng} / \mathrm{mL}\end{array}$ & Estatística \\
\hline $\begin{array}{l}\text { Consumo frequência de carne } \\
1 \text { a } 2 \text { refeições } \\
3 \text { a } 4 \text { refeições } \\
5 \text { a } 9 \text { refeições } \\
10 \text { a } 14 \text { refeições } \\
\text { > } 14 \text { refeições } \\
\text { Não come carne }\end{array}$ & $\begin{array}{c}6(10,9 \%) \\
10(18,2 \%) \\
16(29,1 \%) \\
22(40,0 \%) \\
0(0 \%) \\
1(1,8 \%)\end{array}$ & $\begin{array}{c}7(6,3 \%) \\
15(13,5 \%) \\
41(36,9 \%) \\
46(41,4 \%) \\
1(0,9 \%) \\
1(0,9 \%)\end{array}$ & $\begin{array}{c}17(4,0 \%) \\
55(12,9 \%) \\
171(40,0 \%) \\
178(41,6 \%) \\
2(0,5 \%) \\
5(1,2 \%)\end{array}$ & $p>0,05$ \\
\hline $\begin{array}{l}\text { Tipo de carne que mais come } \\
\text { Frango } \\
\text { Peixe } \\
\text { Porco } \\
\text { Vaca }\end{array}$ & $\begin{array}{c}14(25,9 \%) \\
1(1,9 \%) \\
7(13,0 \%) \\
32(59,3 \%)\end{array}$ & $\begin{array}{c}29(26,4 \%) \\
2(1,8 \%) \\
17(15,5 \%) \\
62(56,4 \%)\end{array}$ & $\begin{array}{c}132(31,2 \%) \\
12(2,8 \%) \\
60(14,2 \%) \\
219(51,8)\end{array}$ & $p>0,05$ \\
\hline $\begin{array}{l}\text { Frequência consumo de leite e } \\
\text { derivados na semana } \\
1 \text { a } 2 \text { vezes } \\
3 \text { a } 4 \text { vezes } \\
5 \text { a } 9 \text { vezes } \\
10 \text { a } 14 \text { vezes } \\
\text { > } 14 \text { vezes } \\
\text { Não consome }\end{array}$ & $\begin{array}{c}5(9,1 \%) \\
13(23,6 \%) \\
21(38,2 \%) \\
10(18,2 \%) \\
2(3,6 \%) \\
4(7,3 \%)\end{array}$ & $\begin{array}{c}19(17,1 \%) \\
23(20,7 \%) \\
42(37,8 \%) \\
17(15,3 \%) \\
1(0,9 \%) \\
9(8,1 \%)\end{array}$ & $\begin{array}{c}79(18,5 \%) \\
87(20,3 \%) \\
161(37,6 \%) \\
59(13,8 \%) \\
4(0,9 \%) \\
38(8,9 \%)\end{array}$ & $p>0,05$ \\
\hline $\begin{array}{l}\text { Vegano } \\
\text { Sim } \\
\text { Não }\end{array}$ & $\begin{array}{c}0(0 \%) \\
55(100 \%)\end{array}$ & $\begin{array}{c}0(0 \%) \\
111(100 \%)\end{array}$ & $\begin{array}{c}2(0,5 \%) \\
426(99,5 \%)\end{array}$ & $p>0,05$ \\
\hline $\begin{array}{l}\text { Vegetariano } \\
\text { Sim } \\
\text { Não }\end{array}$ & $\begin{array}{c}1(1,8 \%) \\
54(98,2 \%)\end{array}$ & $\begin{array}{c}1(0,9 \%) \\
110(99,1 \%)\end{array}$ & $\begin{array}{c}1(0,2 \%) \\
427(99,8 \%)\end{array}$ & $p>0,05$ \\
\hline $\begin{array}{l}\text { Consumo verduras escuras } \\
\text { Sim } \\
\text { Não }\end{array}$ & $\begin{array}{c}47(85,5 \%) \\
8(14,5 \%)\end{array}$ & $\begin{array}{l}95(85,6 \%) \\
16(14,4 \%)\end{array}$ & $\begin{array}{c}375(87,6 \%) \\
53(12,4 \%)\end{array}$ & $p>0,05$ \\
\hline
\end{tabular}

Dados apresentados como frequências observadas (porcentagem). Dados analisados através do teste de qui-quadrado. Diferenças significantes entre os grupos, foram consideradas com $p<0,05$.

FONTE: A Autora, 2019.

Quando comparamos os grupos em relação ao uso de vitaminas, o tipo e o período, não foi observada diferença significante entre os grupos $(p>0,05)$, conforme a Tabela 7. 
Tabela 7 - Comparação das participantes femininas em relação ao uso de suplementos

\begin{tabular}{|c|c|c|c|c|}
\hline & $\begin{array}{c}\text { Ferritina } \\
<30 \mathrm{ng} / \mathrm{mL}\end{array}$ & $\begin{array}{c}\text { Ferritina de } 30 \text { a } \\
60 \mathrm{ng} / \mathrm{mL}\end{array}$ & $\begin{array}{l}\text { Ferritina } \\
>60 \mathrm{ng} / \mathrm{mL}\end{array}$ & Estatística \\
\hline $\begin{array}{l}\text { Em uso de vitamina } \\
\text { Sim } \\
\text { Não }\end{array}$ & $\begin{array}{l}13(12 \%) \\
95(88 \%)\end{array}$ & $\begin{array}{l}25(20,2 \%) \\
99(79,8 \%)\end{array}$ & $\begin{array}{c}17(10,6 \%) \\
143(89,4 \%)\end{array}$ & $p>0,05$ \\
\hline $\begin{array}{l}\text { Qual vitamina } \\
\text { Sulfato ferroso } \\
\text { Complexo B } \\
\text { Ácido fólico } \\
\text { Polivitamínico }\end{array}$ & $\begin{array}{c}0(0 \%) \\
0(0 \%) \\
0(0 \%) \\
13(100 \%)\end{array}$ & $\begin{array}{c}3(12,0 \%) \\
3(12,0 \%) \\
1(4,0 \%) \\
18(72,0 \%)\end{array}$ & $\begin{array}{c}1(5,9 \%) \\
2(11,8 \%) \\
1(5,9 \%) \\
13(76,5 \%)\end{array}$ & $p>0,05$ \\
\hline $\begin{array}{l}\text { Há quanto tempo } \\
\quad<1 \text { mês } \\
\quad 1 \text { a } 6 \text { meses } \\
\text { > } 6 \text { meses }\end{array}$ & $\begin{array}{l}2(15,4 \%) \\
5(38,5 \%) \\
6(46,1 \%)\end{array}$ & $\begin{array}{c}3(12,0 \%) \\
10(40,0 \%) \\
12(48,0 \%)\end{array}$ & $\begin{array}{l}3(17,6 \%) \\
7(41,2 \%) \\
7(41,2 \%)\end{array}$ & $p>0,05$ \\
\hline
\end{tabular}

Dados apresentados como frequências observadas (porcentagem). Dados analisados através do teste de quiquadrado. Diferenças significantes entre os grupos, foram consideradas com $p<0,05$.

FONTE: A Autora, 2019.

Quando comparamos os grupos em relação ao uso de vitaminas, qual tipo e há quanto tempo, não observamos diferença significante entre os grupos $(p>0,05)$, conforme Tabela 8.

Tabela 8- Comparação dos participantes masculinos em relação ao uso de suplementos

\begin{tabular}{|c|c|c|c|c|}
\hline & $\begin{array}{l}\text { Ferritina } \\
<30 \mathrm{ng} / \mathrm{mL}\end{array}$ & $\begin{array}{c}\text { Ferritina de } 30 \text { a } \\
60 \mathrm{ng} / \mathrm{mL}\end{array}$ & $\begin{array}{c}\text { Ferritina } \\
>60 \mathrm{ng} / \mathrm{mL}\end{array}$ & Estatística \\
\hline $\begin{array}{l}\text { Em uso de vitaminas } \\
\text { Sim } \\
\text { Não }\end{array}$ & $\begin{array}{c}1(1,8 \%) \\
54(98,2 \%)\end{array}$ & $\begin{array}{l}14(12,6 \%) \\
97(87,4 \%)\end{array}$ & $\begin{array}{c}35(8,2 \%) \\
393(91,8 \%)\end{array}$ & $p>0,05$ \\
\hline $\begin{array}{l}\text { Qual vitamina } \\
\text { Complexo B } \\
\text { Ácido fólico } \\
\text { Polivitamínico }\end{array}$ & $\begin{array}{c}0(0 \%) \\
0(0 \%) \\
1(100 \%)\end{array}$ & $\begin{array}{c}2(14,3 \%) \\
0(0 \%) \\
12(85,7 \%)\end{array}$ & $\begin{array}{c}4(11,4 \%) \\
1(2,9 \%) \\
30(85,7 \%)\end{array}$ & $p>0,05$ \\
\hline $\begin{array}{l}\text { Há quanto tempo } \\
\quad<1 \text { mês } \\
\quad 1 \text { a } 6 \text { meses } \\
\quad>6 \text { meses }\end{array}$ & $\begin{array}{c}0(0 \%) \\
0(0 \%) \\
1(100 \%)\end{array}$ & $\begin{array}{l}3(21,4 \%) \\
5(35,7 \%) \\
6(42,9 \%)\end{array}$ & $\begin{array}{c}8(22,9 \%) \\
11(31,4 \%) \\
16(45,7 \%)\end{array}$ & $p>0,05$ \\
\hline
\end{tabular}

Dados apresentados como frequências observadas (porcentagem). Dados analisados através do teste de quiquadrado. Diferenças significantes entre os grupos, foram consideradas com $p<0,05$.

FONTE: A Autora,2019

Na Tabela 9, de acordo com os hábitos de vida e socioculturais não foram observadas diferenças em relação ao índice de massa corporal, consumo de bebida alcoólica, tabagismo, e se eram ex-fumantes, com p>0,05. 
Tabela 9 - Comparação das participantes femininas de acordo com seus hábitos de vida e socioculturais

\begin{tabular}{|c|c|c|c|c|}
\hline & $\begin{array}{c}\text { Ferritina } \\
<30 \mathrm{ng} / \mathrm{mL}\end{array}$ & $\begin{array}{c}\text { Ferritina de } 30 \\
\text { a } 60 \mathrm{ng} / \mathrm{mL}\end{array}$ & $\begin{array}{l}\text { Ferritina } \\
>60 \mathrm{ng} / \mathrm{mL}\end{array}$ & Estatística \\
\hline $\operatorname{IMC}\left(\mathrm{Kg} / \mathrm{m}^{2}\right)$ & $27(23-32)^{a}$ & $25(23-30)^{\mathrm{a}}$ & $25(23-28)^{a}$ & $p>0,05$ \\
\hline $\begin{array}{l}\text { Consome bebida alcoólica } \\
\text { Sim } \\
\text { Não }\end{array}$ & $\begin{array}{l}53(49,1 \%) \\
55(50,9 \%)\end{array}$ & $\begin{array}{l}62(50,0 \%) \\
62(50,0 \%)\end{array}$ & $\begin{array}{l}95(59,4 \%) \\
65(40,6 \%)\end{array}$ & $p>0,05$ \\
\hline $\begin{array}{l}\text { Fuma cigarro de papel } \\
\text { Sim } \\
\text { Não }\end{array}$ & $\begin{array}{c}8(7,4 \%) \\
100(92,6 \%)\end{array}$ & $\begin{array}{c}5(4,0 \%) \\
119(96,0 \%)\end{array}$ & $\begin{array}{c}8(5,0 \%) \\
152(95,0 \%)\end{array}$ & $p>0,05$ \\
\hline $\begin{array}{l}\text { Ex-fumante } \\
\text { Sim } \\
\text { Não }\end{array}$ & $\begin{array}{l}15(15 \%) \\
85(85 \%) \\
\end{array}$ & $\begin{array}{c}10(8,4 \%) \\
109(91,6 \%) \\
\end{array}$ & $\begin{array}{c}20(13,2 \%) \\
132(86,8 \%) \\
\end{array}$ & $p>0,05$ \\
\hline
\end{tabular}

Dados apresentados como frequências observadas (porcentagem). Dados analisados através do teste de quiquadrado. Diferenças significantes entre os grupos, foram consideradas com $p<0,05$.

FONTE: A Autora, 2019.

Tabela 10 - Comparação dos participantes masculinos de acordo com seus hábitos de vida e socioculturais

\begin{tabular}{lcccc}
\hline & $\begin{array}{c}\text { Ferritina } \\
<30 \mathbf{n g} / \mathbf{m L}\end{array}$ & $\begin{array}{c}\text { Ferritina de 30 } \\
\mathbf{a} 60 \mathbf{n g} / \mathbf{m L}\end{array}$ & $\begin{array}{c}\text { Ferritina } \\
>60 \mathbf{n g} / \mathbf{m L}\end{array}$ & Estatística \\
\hline IMC $\left(\mathrm{Kg} / \mathrm{m}^{2}\right)$ & $25(22-27)^{\mathrm{ab}}$ & $25(23-28)^{\mathrm{a}}$ & $26(24-29)^{\mathrm{b}}$ & $\mathrm{p}<0,05$ \\
Consome bebida alcoólica & $28(50,9 \%)$ & $50(45 \%)$ & $275(64,3 \%)$ & \\
$\quad$ Sim & $27(49,1 \%)$ & $61(55 \%)$ & $153(35,7 \%)$ & $\mathrm{p}<0,0001$ \\
$\quad$ Não & $3(5,5 \%)$ & $8(7,2 \%)$ & $32(7,5 \%)$ & \\
Fuma cigarro de papel & $52(94,55)$ & $103(92,8 \%)$ & $396(92,5 \%)$ & $\mathrm{p}>0,05$ \\
$\quad$ Sim & $3(5,8 \%)$ & $12(11,7 \%)$ & $12(11,7 \%)$ & \\
$\quad$ Não & $49(94,2 \%)$ & $91(88,3 \%)$ & $91(88,3 \%)$ & $\mathrm{p}>0,05$ \\
Ex-fumante & & & \\
$\quad$ Sim & Não & &
\end{tabular}

Dados apresentados como frequências observadas (porcentagem). Dados analisados através do teste de quiquadrado. Diferenças significantes entre os grupos, foram consideradas com $p<0,05$.

FONTE: A Autora, 2019.

Na Tabela 10, de acordo com os hábitos de vida e socioculturais, o consumo de bebida alcoólica está relacionado a variação de ferritina $(p<0,0001)$. Não foram observadas diferenças em relação ao tabagismo e se eram ex-fumantes (com $p>0,05)$. Observarmos que as maiores concentrações de ferritina foram encontradas nos doadores com maior índice de massa corporal, em relação aos com concentração entre 30 e $60 \mathrm{ng} / \mathrm{mL}$. Ambos grupos não foram diferentes dos que apresentaram concentração de ferritina menor que $30 \mathrm{ng} / \mathrm{mL}$. 
Gráfico 4 - Representação das frequências dos participantes do estudo do sexo masculino de acordo em relação ao IMC e concentração de ferritina sérica.

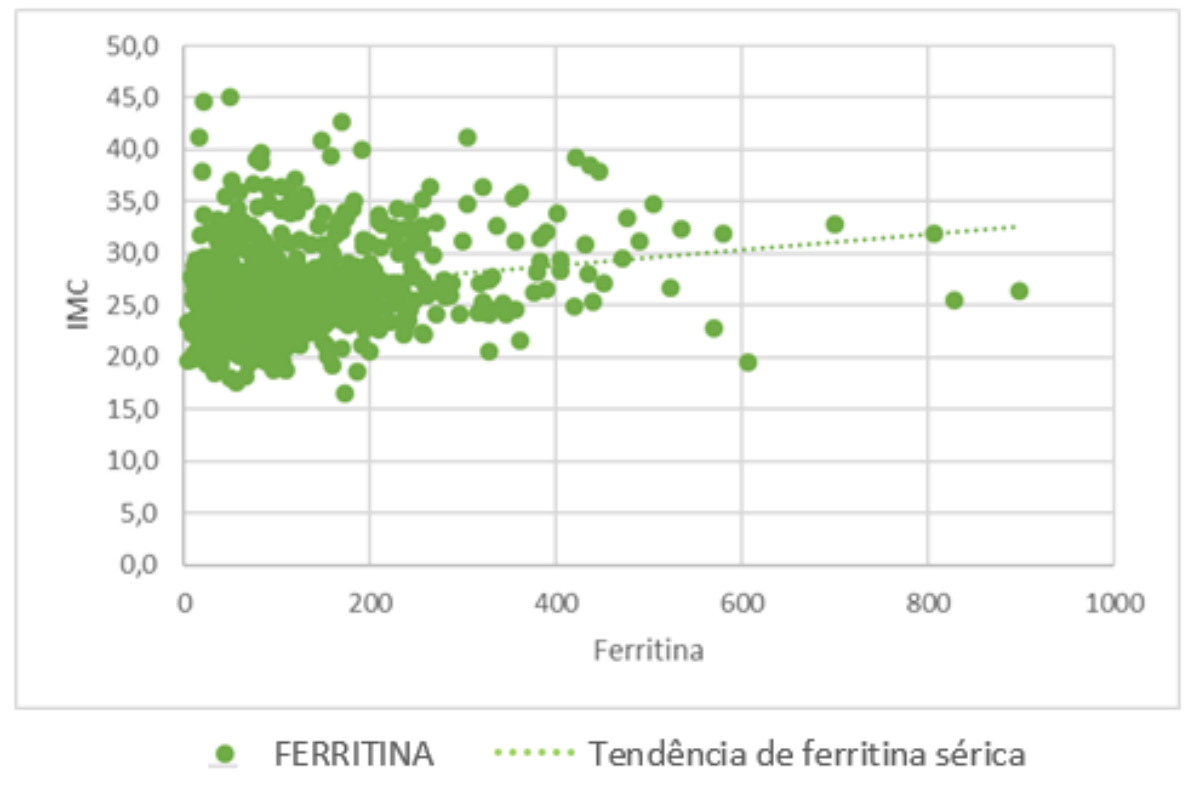

FONTE: A Autora, 2019.

Na tabela 11, não observamos diferença significante entre os grupos quando comparamos as concentrações de ferritina de acordo com a estratificação do índice de massa corporal em menor de $18 \mathrm{Kg} / \mathrm{m}^{2}$, entre 18 e $25 \mathrm{Kg} / \mathrm{m}^{2}$ e maior que 26 $\mathrm{Kg} / \mathrm{m}^{2}$.

Tabela 11 - Comparação das concentrações de ferritina de acordo com a estratificação do índice de massa corporal nas mulheres

IMC

\begin{tabular}{|c|c|c|c|c|}
\hline & \multicolumn{3}{|c|}{ IMC } & \multirow{2}{*}{ Estatística } \\
\hline & $<18 \mathrm{Kg} / \mathrm{m}^{2}$ & Entre 18 e $25 \mathrm{Kg} / \mathrm{m}^{2}$ & $>26 \mathrm{Kg} / \mathrm{m}^{2}$ & \\
\hline Ferrit & $103(33,5-113)^{\mathrm{a}}$ & $49,5(29-83)^{a}$ & $51(24-81)^{\mathrm{a}}$ & $p>0,05$ \\
\hline
\end{tabular}

Dados apresentados como mediana e intervalos interquartis. Diferenças significantes entre os grupos, foram consideradas com $p<0,05$. Dados analisados através do teste de Kruskall-Wallis com pós teste de Dunn e teste de qui-quadrado. Diferenças significantes entre os grupos, foram consideradas com $p<0,05$.

FONTE: A Autora, 2019.

$\mathrm{Na}$ Tabela 12, ao avaliar o histórico obstétrico foram observadas diferenças significantes em relação se a paciente ainda menstrua, se possui hipermenorreia e quanto ao número de gestações $(p<0,05)$. Se a mulher teve gestação não apresentou diferença significante entre os grupos $(p>0,05)$. 
Tabela 12 - Comparação das participantes femininas de acordo com o histórico obstétrico

\begin{tabular}{|c|c|c|c|c|}
\hline & $\begin{array}{l}\text { Ferritina } \\
<30 \mathrm{ng} / \mathrm{mL}\end{array}$ & $\begin{array}{c}\text { Ferritina de } 30 \text { a } \\
60 \mathrm{ng} / \mathrm{mL}\end{array}$ & $\begin{array}{c}\text { Ferritina } \\
>60 \mathrm{ng} / \mathrm{mL}\end{array}$ & Estatística \\
\hline \multicolumn{5}{|l|}{ Menstrua } \\
\hline $\begin{array}{l}\text { Sim } \\
\text { Não }\end{array}$ & $\begin{array}{l}89(82,4 \%) \\
19(17,6 \%)\end{array}$ & $\begin{array}{l}101(81,5 \%) \\
23(18,5 \%)\end{array}$ & $\begin{array}{c}113(70,6 \%) \\
47(29,4 \%)\end{array}$ & $p<0,05$ \\
\hline \multicolumn{5}{|l|}{ Hipermenorreia } \\
\hline $\begin{array}{l}\text { Sim } \\
\text { Não }\end{array}$ & $\begin{array}{l}57(64 \%) \\
32(36 \%)\end{array}$ & $\begin{array}{l}86(85,1 \%) \\
15(14,9 \%)\end{array}$ & $\begin{array}{l}56(49,6 \%) \\
57(50,4 \%)\end{array}$ & $p<0,0001$ \\
\hline \multicolumn{5}{|l|}{ Engravidou } \\
\hline $\begin{array}{l}\text { Sim } \\
\text { Não } \\
\text { Não se aplica }\end{array}$ & $\begin{array}{c}66(61,1 \%) \\
41(38 \%) \\
1(0,9 \%)\end{array}$ & $\begin{array}{c}61(49,2 \%) \\
62(50,0 \%) \\
1(0,8 \%)\end{array}$ & $\begin{array}{c}91(56,9 \%) \\
65(40,6 \%) \\
4(2,5 \%)\end{array}$ & $p>0,05$ \\
\hline \multicolumn{5}{|l|}{ Número gestações } \\
\hline $\begin{array}{l}\text { Uma } \\
\text { Duas } \\
\text { Três } \\
\text { Quatro } \\
\end{array}$ & $\begin{array}{c}28(42,4 \%) \\
32(48,5 \%) \\
5(7,6 \%) \\
1(1,5 \%) \\
\end{array}$ & $\begin{array}{c}21(34,4 \%) \\
23(37,7 \%) \\
16(26,2 \%) \\
1(1,6 \%) \\
\end{array}$ & $\begin{array}{c}36(39,6 \%) \\
40(44,0 \%) \\
9(9,9 \%) \\
6(6,6 \%) \\
\end{array}$ & $p<0,05$ \\
\hline
\end{tabular}

Dados apresentados como frequências observadas (porcentagem). Dados analisados através do teste de quiquadrado. Diferenças significantes entre os grupos, foram consideradas com $p<0,05$.

FONTE: A Autora, 2019.

Quando comparamos os grupos em relação se já teve anemia, observamos diferença significante $(p<0,05)$, o que não foi observado quando avaliado sobre tratamento prévio com ferro, conforme exposto na Tabela 13.

Tabela 13 - Comparação das participantes femininas de acordo com presença de anemia prévia e tratamento com ferro

\begin{tabular}{|c|c|c|c|c|}
\hline & $\begin{array}{c}\text { Ferritina } \\
<30 \mathrm{ng} / \mathrm{mL}\end{array}$ & $\begin{array}{c}\text { Ferritina de } 30 \text { a } \\
60 \mathrm{ng} / \mathrm{mL}\end{array}$ & $\begin{array}{l}\text { Ferritina } \\
>60 \mathrm{ng} / \mathrm{mL}\end{array}$ & Estatística \\
\hline $\begin{array}{l}\text { Já teve anemia } \\
\text { Sim } \\
\text { Não }\end{array}$ & $\begin{array}{l}26(24,1 \%) \\
82(75,9 \%)\end{array}$ & $\begin{array}{c}17(13,7 \%) \\
107(86,3 \%)\end{array}$ & $\begin{array}{c}41(25,6 \%) \\
119(74,4 \%)\end{array}$ & $p<0,05$ \\
\hline $\begin{array}{l}\text { Tratamento com ferro } \\
\text { Sim } \\
\text { Não }\end{array}$ & $\begin{array}{l}21(19,4 \%) \\
87(80,6 \%)\end{array}$ & $\begin{array}{c}17(13,7 \%) \\
107(86,3 \%)\end{array}$ & $\begin{array}{c}34(21,3 \%) \\
126(78,8 \%)\end{array}$ & $p>0,05$ \\
\hline
\end{tabular}

Dados apresentados como frequências observadas (porcentagem). Dados analisados através do teste de quiquadrado. Diferenças significantes entre os grupos, foram consideradas com $p<0,05$.

FONTE: A Autora, 2019.

$\mathrm{Na}$ Tabela 14, correlacionando as comorbidades, não foram observadas diferenças em relação ao uso de inibidores de bomba, sangramento do tubo digestivo, epistaxe e doenças descamativas da pele, com $p>0,05$. 
Tabela 14 - Comparação entre os grupos femininos de acordo com a presença de comorbidades

\begin{tabular}{|c|c|c|c|c|}
\hline & $\begin{array}{l}\begin{array}{l}\text { Ferritina } \\
<30 \mathrm{ng} / \mathrm{mL}\end{array}\end{array}$ & $\begin{array}{c}\text { Ferritina de } 30 \text { a } \\
60 \mathrm{ng} / \mathrm{mL}\end{array}$ & $\begin{array}{l}\text { Ferritina } \\
>60 \mathrm{ng} / \mathrm{mL}\end{array}$ & Estatística \\
\hline $\begin{array}{l}\text { Inibidores de bomba } \\
\text { Presente } \\
\text { Ausente }\end{array}$ & $\begin{array}{c}2(1,9 \%) \\
106(98,1 \%)\end{array}$ & $\begin{array}{c}1(0,8 \%) \\
123(99,2 \%)\end{array}$ & $\begin{array}{c}4(2,5 \%) \\
156(97,5 \%)\end{array}$ & $p>0,05$ \\
\hline $\begin{array}{l}\text { Sangramento tudo dige } \\
\text { Presente } \\
\text { Ausente }\end{array}$ & $\begin{array}{c}0(0 \%) \\
108(100 \%)\end{array}$ & $\begin{array}{c}1(0,8 \%) \\
123(99,2 \%)\end{array}$ & $\begin{array}{c}3(1,9 \%) \\
157(98,1 \%)\end{array}$ & $p>0,05$ \\
\hline $\begin{array}{l}\text { Má absorção intestinal } \\
\text { Ausente }\end{array}$ & $108(100 \%)$ & $124(100 \%)$ & 160 (100\%) & $N A$ \\
\hline $\begin{array}{l}\text { Doença celíaca } \\
\text { Ausente }\end{array}$ & $108(100 \%)$ & 124 (100\%) & 160 (100\%) & $N A$ \\
\hline $\begin{array}{l}\text { Epistaxe } \\
\quad \text { Ausente }\end{array}$ & $108(100 \%)$ & $124(100 \%)$ & 160 (100\%) & $N A$ \\
\hline $\begin{array}{l}\text { Doenças descamativas } \\
\text { pele } \\
\quad \text { Presente } \\
\text { Ausente }\end{array}$ & $\begin{array}{c}2(1,9 \%) \\
106(98,1 \%)\end{array}$ & $\begin{array}{c}1(0,8 \%) \\
123(99,2 \%)\end{array}$ & $\begin{array}{c}0(0 \%) \\
160(100 \%)\end{array}$ & $p>0,05$ \\
\hline $\begin{array}{l}\text { Doenças respiratórias } \\
\text { Ausente }\end{array}$ & 108 (100\%) & 124 (100\%) & 160 (100\%) & $N A$ \\
\hline
\end{tabular}

Dados apresentados como mediana e intervalos interquartis e frequências observadas (porcentagem). Letras diferentes indicam diferença significante entre os grupos. Dados analisados através do teste de Kruskall-Wallis com pós teste de Dunn e teste de qui-quadrado. Diferenças significantes entre os grupos, foram consideradas com $\mathrm{p}<0,05$. $N A-\mathrm{Não}$ se aplica.

FONTE: A Autora, 2019.

$\mathrm{Na}$ tabela 15, não observamos diferença significante entre os grupos quando comparamos as concentrações de ferritina de acordo com a estratificação do índice de massa corporal em menor de $18 \mathrm{Kg} / \mathrm{m}^{2}$, entre 18 e $25 \mathrm{Kg} / \mathrm{m}^{2}$ e maior que 26 $\mathrm{Kg} / \mathrm{m}^{2}$.

Tabela 15 - Comparação das concentrações de ferritina de acordo com a estratificação do índice de massa corporal nos homens

\begin{tabular}{ccccc}
\hline & \multicolumn{3}{c}{ IMC } & \multirow{2}{*}{ Estatística } \\
\cline { 2 - 4 } & $<\mathbf{1 8 ~ K g} / \mathbf{m}^{2}$ & Entre $\mathbf{1 8 ~ e ~} \mathbf{2 5 ~ K g} / \mathbf{m}^{2}$ & $>\mathbf{2 6 ~ K g} / \mathbf{m}^{2}$ & \\
\cline { 2 - 5 } Ferritina $(\mathbf{n g} / \mathrm{mL})$ & $53,5(34,2-89,2)^{\mathrm{a}}$ & $63(35,7-97)^{\mathrm{a}}$ & $66,5(41,2-97)^{\mathrm{a}}$ & $\mathrm{p}>0,05$ \\
\hline
\end{tabular}

Dados apresentados como mediana e intervalos interquartis. Diferenças significantes entre os grupos, foram consideradas com $p<0,05$. Dados analisados através do teste de Kruskall-Wallis com pós teste de Dunn e teste de qui-quadrado. Diferenças significantes entre os grupos, foram consideradas com $p<0,05$.

FONTE: A Autora, 2019. 
$\mathrm{Na}$ Tabela 16, comparamos os grupos em relação a presença de anemia e tratamento prévio com ferro, não observamos diferença significante entre os grupos, com $p>0,05$.

Tabela 16 - Comparação dos homens em relação a presença de anemia prévia e tratamento com ferro

\begin{tabular}{|c|c|c|c|c|}
\hline & $\begin{array}{c}\text { Ferritina } \\
<30 \mathrm{ng} / \mathrm{mL}\end{array}$ & $\begin{array}{c}\text { Ferritina de } 30 \text { a } \\
60 \mathrm{ng} / \mathrm{mL}\end{array}$ & $\begin{array}{c}\text { Ferritina } \\
>60 \mathrm{ng} / \mathrm{mL}\end{array}$ & Estatística \\
\hline $\begin{array}{l}\text { Já teve anemia } \\
\text { Sim } \\
\text { Não }\end{array}$ & $\begin{array}{c}1(1,8 \%) \\
54(98,2 \%)\end{array}$ & $\begin{array}{c}3(2,7 \%) \\
108(97,3 \%)\end{array}$ & $\begin{array}{c}19(4,4 \%) \\
409(95,6 \%)\end{array}$ & $p>0,05$ \\
\hline $\begin{array}{l}\text { Tratamento com ferro } \\
\text { Sim } \\
\text { Não }\end{array}$ & $\begin{array}{c}0(0 \%) \\
55(100 \%)\end{array}$ & $\begin{array}{c}2(1,8 \%) \\
109(98,2 \%)\end{array}$ & $\begin{array}{c}16(3,7 \%) \\
412(96,3 \%)\end{array}$ & $p>0,05$ \\
\hline
\end{tabular}

Dados apresentados como frequências observadas (porcentagem). Dados analisados através do teste de quiquadrado. Diferenças significantes entre os grupos, foram consideradas com $p<0,05$.

FONTE: A Autora, 2019.

$\mathrm{Na}$ Tabela 17, ao correlacionarmos as comorbidades, não foram observadas diferenças em relação ao uso de inibidores de bomba, sangramento do tubo digestivo, doenças descamativas da pele e doenças respiratórias, com $p>0,05$. A presença de epistaxe apresentou correlação significante entre os grupos $(p<0,01)$.

Tabela 17 - Comparação entre os grupos masculinos de acordo com a presença de comorbidades

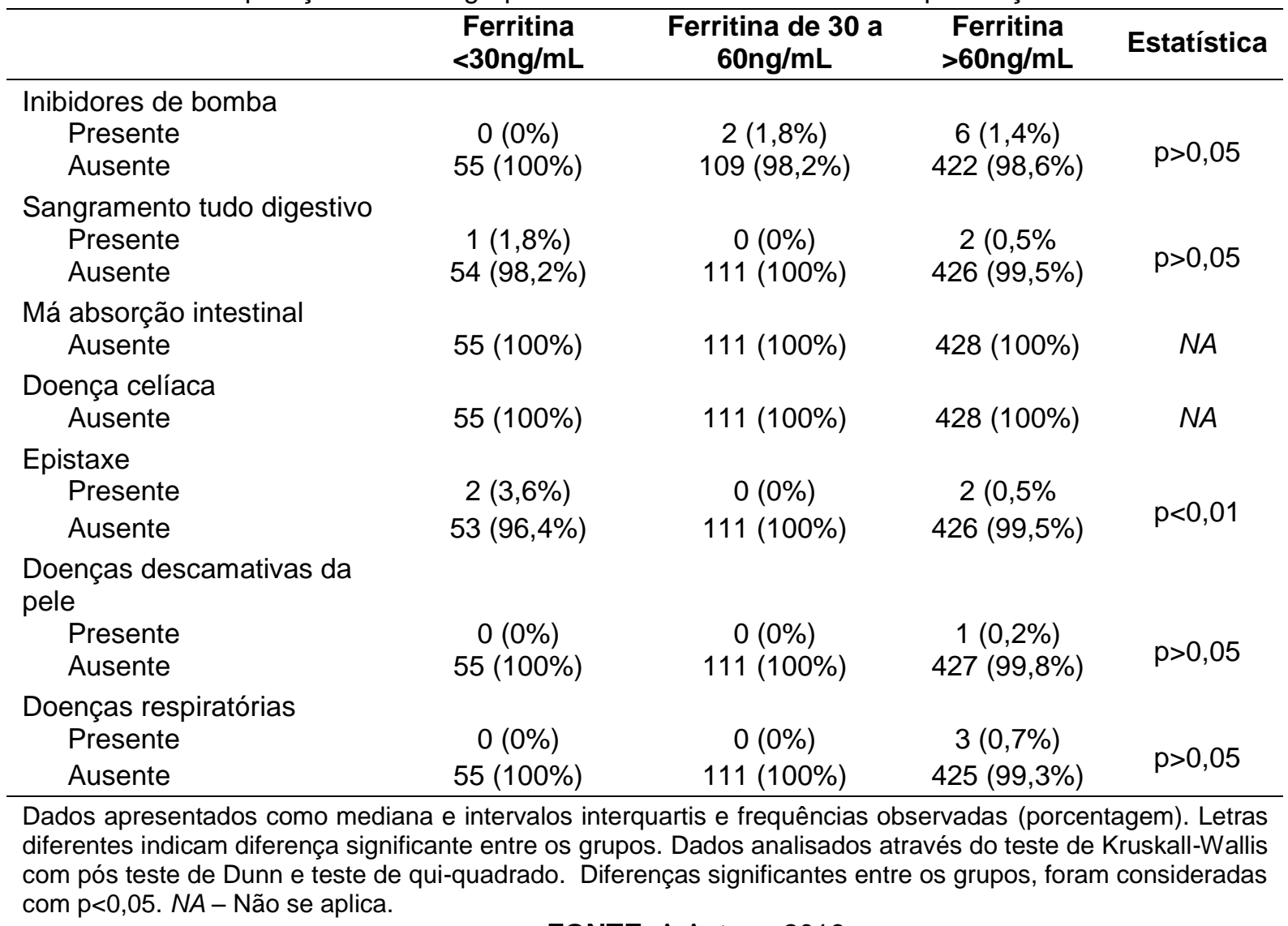

FONTE: A Autora, 2019. 
$\mathrm{Na}$ tabela 18, foi encontrada correlação significante entre as faixas etárias dos participantes com as concentrações de ferritina encontradas $(p<0,05)$.

Tabela 18 - Relação entre concentração de ferritina encontrada de acordo com a faixa etária das doadoras do sexo feminino

\begin{tabular}{ccccc}
\hline & \multicolumn{3}{c}{ Idade } & Estatística \\
\cline { 2 - 4 } $\begin{array}{c}\text { Concentração } \\
\text { de ferritina }\end{array}$ & $\mathbf{1 8}$ a $\mathbf{3 0}$ anos & $\mathbf{3 1}$ a $\mathbf{4 5}$ anos & $\mathbf{4 6}$ a $\mathbf{6 0}$ anos & \\
\hline$<30 \mathrm{ng} / \mathrm{mL}$ & 59 & 63 & 38 & \\
$30 \mathrm{a} 60 \mathrm{ng} / \mathrm{mL}$ & 62 & 44 & 18 & $\mathrm{p}<0,05$ \\
$>60 \mathrm{ng} / \mathrm{mL}$ & 38 & 18 & 14 & \\
\hline
\end{tabular}

Dados apresentados como frequência observada. Dados analisados através do teste de qui-quadrado. Diferenças significantes entre os grupos, foram consideradas com $p<0,05$.

FONTE: A Autora, 2019.

Diferente do observado no grupo feminino, na Tabela 19 não observamos diferente significante entre os grupos do sexo masculino quando correlacionamos as concentrações encontradas e as faixas etárias.

Tabela 19 - Relação entre concentração de ferritina encontrada de acordo com a faixa etária dos pacientes do sexo masculino

\begin{tabular}{ccccc}
\hline & \multicolumn{3}{c}{ Idade } & \multirow{2}{*}{ Estatística } \\
\cline { 2 - 4 } $\begin{array}{c}\text { Concentração } \\
\text { de ferritina }\end{array}$ & $\mathbf{1 8}$ a $\mathbf{3 0}$ anos & $\mathbf{3 1}$ a $\mathbf{4 5}$ anos & $\mathbf{4 6}$ a $\mathbf{6 0}$ anos & \\
\hline$<30 \mathrm{ng} / \mathrm{mL}$ & 149 & 174 & 105 & \\
$30 \mathrm{a} 60 \mathrm{ng} / \mathrm{mL}$ & 48 & 45 & 18 & $\mathrm{p}>0,05$ \\
$>60 \mathrm{ng} / \mathrm{mL}$ & 21 & 22 & 12 & \\
\hline
\end{tabular}

Dados apresentados como frequência observada. Dados analisados através do teste de qui-quadrado. Diferenças significantes entre os grupos, foram consideradas com $\mathrm{p}<0,05$.

FONTE: A Autora, 2019.

$\mathrm{Na}$ tabela 20, foi encontrada correlação significante entre os sexos dos participantes com as concentrações de ferritina encontradas $(p<0,05)$.

Tabela 20 - Comparação dos primodoadores entre os grupos masculinos e femininos

\begin{tabular}{|c|c|c|c|c|}
\hline & $\begin{array}{l}\text { Ferritina } \\
<30 \mathrm{ng} / \mathrm{mL}\end{array}$ & $\begin{array}{c}\text { Ferritina de } 30 \\
\text { a } 60 \mathrm{ng} / \mathrm{mL}\end{array}$ & $\begin{array}{l}\text { Ferritina } \\
>60 \mathrm{ng} / \mathrm{mL}\end{array}$ & Estatística \\
\hline \multicolumn{5}{|l|}{ Sexo } \\
\hline Feminino & $22(75,9 \%)$ & $24(68,6 \%)$ & $47(37,3 \%)$ & \\
\hline Masculino & $7(24,1 \%)$ & $11(31,4 \%)$ & 79 (62,7\%) & 0001 \\
\hline
\end{tabular}

Dados apresentados como frequências observadas (porcentagem). Dados analisados através do teste de qui-quadrado. Diferenças significantes entre os grupos, foram consideradas com $p<0,05$.

FONTE: A Autora, 2019. 
$\mathrm{Na}$ tabela 21, mulheres e homens, doadores de primeira vez, foram analisados de acordo com sua ingesta alimentar, e não foram observadas correlações entre o consumo de carne, tipo de carne, consumo de leite e derivados, consumo de verduras escuras, bem como uso de bebida alcoolica ou cigarro de papel, com $\mathrm{p}>0,05$.

Tabela 21 - Frequência observada dos grupos femininos com Ferritina $<30 \mathrm{ng} / \mathrm{mL}$ (A), Ferritina de 30 a $60 \mathrm{ng} / \mathrm{mL}$ (B), Ferritina $>60 \mathrm{ng} / \mathrm{mL}$ (C), com os masculinos portadores de Ferritina $<30 \mathrm{ng} / \mathrm{mL}$ (D), Ferritina de 30 a $60 \mathrm{ng} / \mathrm{mL}(E)$, Ferritina $>60 \mathrm{ng} / \mathrm{mL}(\mathrm{F})$

\begin{tabular}{|c|c|c|c|c|c|c|}
\hline & \multicolumn{3}{|c|}{ Feminino } & \multicolumn{3}{|c|}{ Masculino } \\
\hline & Grupo A & Grupo B & Grupo C & Grupo D & Grupo E & Grupo F \\
\hline \multicolumn{7}{|l|}{$\begin{array}{l}\text { Tipo de carne } \\
\text { que mais come }\end{array}$} \\
\hline Frango & 9 & 12 & 17 & 1 & 3 & 25 \\
\hline Peixe & 1 & 1 & 2 & 1 & 1 & 1 \\
\hline Porco & 1 & 3 & 4 & 1 & 3 & 10 \\
\hline Vaca & 11 & 7 & 25 & 6 & 6 & 40 \\
\hline $\begin{array}{l}\text { Não come } \\
\text { Estatística }\end{array}$ & 1 & $\begin{array}{c}1 \\
p>0,05\end{array}$ & 1 & 1 & $\begin{array}{c}1 \\
p>0,05\end{array}$ & 1 \\
\hline \multicolumn{7}{|l|}{$\begin{array}{l}\text { Consumo de } \\
\text { leite e derivados }\end{array}$} \\
\hline Consome & 21 & 22 & 42 & 7 & 11 & 57 \\
\hline $\begin{array}{l}\text { Não consome } \\
\text { Estatística }\end{array}$ & 1 & $\begin{array}{c}2 \\
p>0,05\end{array}$ & 5 & 1 & $\begin{array}{c}2 \\
p>0,05\end{array}$ & 12 \\
\hline \multicolumn{7}{|l|}{$\begin{array}{l}\text { Consumo de } \\
\text { verduras } \\
\text { escuras }\end{array}$} \\
\hline $\begin{array}{l}\text { Consome } \\
\text { Não consome } \\
\text { Estatística }\end{array}$ & $\begin{array}{l}30 \\
2\end{array}$ & $\begin{array}{c}23 \\
1 \\
p>0,05\end{array}$ & $\begin{array}{c}45 \\
2\end{array}$ & $\begin{array}{l}7 \\
1\end{array}$ & $\begin{array}{c}10 \\
1 \\
p>0,05\end{array}$ & $\begin{array}{l}62 \\
17\end{array}$ \\
\hline \multicolumn{7}{|l|}{$\begin{array}{l}\text { Consumo de } \\
\text { bebidas alcoólica }\end{array}$} \\
\hline Consome & 9 & 13 & 27 & 6 & 6 & 53 \\
\hline Não consome & 13 & 11 & 20 & 1 & 5 & 26 \\
\hline Estatística & & $p>0,05$ & & & $p>0,05$ & \\
\hline
\end{tabular}

Dados apresentados como frequências observadas (porcentagem). Dados analisados através do teste de quiquadrado. Diferenças significantes entre os grupos, foram consideradas com $p<0,05$.

FONTE: A Autora, 2019.

No presente estudo também houve uma maior prevalência de doadores do sexo feminino com depleção de ferro. Em relação à hemoglobina próxima ao limite inferior, $83 \%$ dos doadores eram mulheres, e $77 \%$ desse grupo apresentavam ferritina inferior a $12 \mathrm{ng} / \mathrm{mL}$ (Tabela 22). 
Tabela 22 - Resultado Hemoglobina X intervalo de ferritina X sexo

\begin{tabular}{|c|c|c|c|c|c|c|c|c|c|c|c|c|c|}
\hline \multirow{2}{*}{ Grupos } & \multirow{2}{*}{ № de doações } & \multirow{2}{*}{$\begin{array}{c}<13,5 \\
M\end{array}$} & \multirow{2}{*}{$\frac{<13,0}{F}$} & \multicolumn{2}{|c|}{$\begin{array}{c}\text { Ferritina } \\
<12 \mathrm{ng} / \mathrm{mL}\end{array}$} & \multicolumn{2}{|c|}{$\begin{array}{c}\text { Ferritina } \\
12 \text { a } 15 \mathrm{ng} / \mathrm{mL}\end{array}$} & \multicolumn{2}{|c|}{$\begin{array}{c}\text { Ferritina } \\
16 \text { a } 30 \mathrm{ng} / \mathrm{mL}\end{array}$} & \multicolumn{2}{|c|}{$\begin{array}{c}\text { Ferritina } \\
31 \mathrm{a} 60 \mathrm{ng} / \mathrm{mL}\end{array}$} & \multicolumn{2}{|c|}{$\begin{aligned} & \text { Ferritina } \\
> & 60 \mathrm{ng} / \mathrm{mL}\end{aligned}$} \\
\hline & & & & $M$ & $\mathrm{~F}$ & $M$ & $\mathrm{~F}$ & $M$ & $\mathrm{~F}$ & $M$ & $\mathrm{~F}$ & $M$ & $\mathrm{~F}$ \\
\hline$\|$ & 1 a 4 & 5 & 24 & 1 & 16 & 3 & 7 & 16 & 27 & 53 & 70 & 203 & 82 \\
\hline III & 5 a 9 & 3 & 14 & 4 & 5 & 2 & 8 & 9 & 13 & 24 & 21 & 97 & 25 \\
\hline IV & $>10$ & 2 & 9 & 1 & 4 & 4 & 0 & 10 & 4 & 15 & 5 & 49 & 6 \\
\hline
\end{tabular}

FONTE: A Autora, 2019.

A medida que os intervalos de ferritina vão aumentando o percentual de mulheres vai diminuindo, comprovando que valores de ferritina menores são mais frequentes em mulheres (Gráfico 5).

Gráfico 5 - Representação entre intervalos de ferritina e percentual de mulheres doadoras.

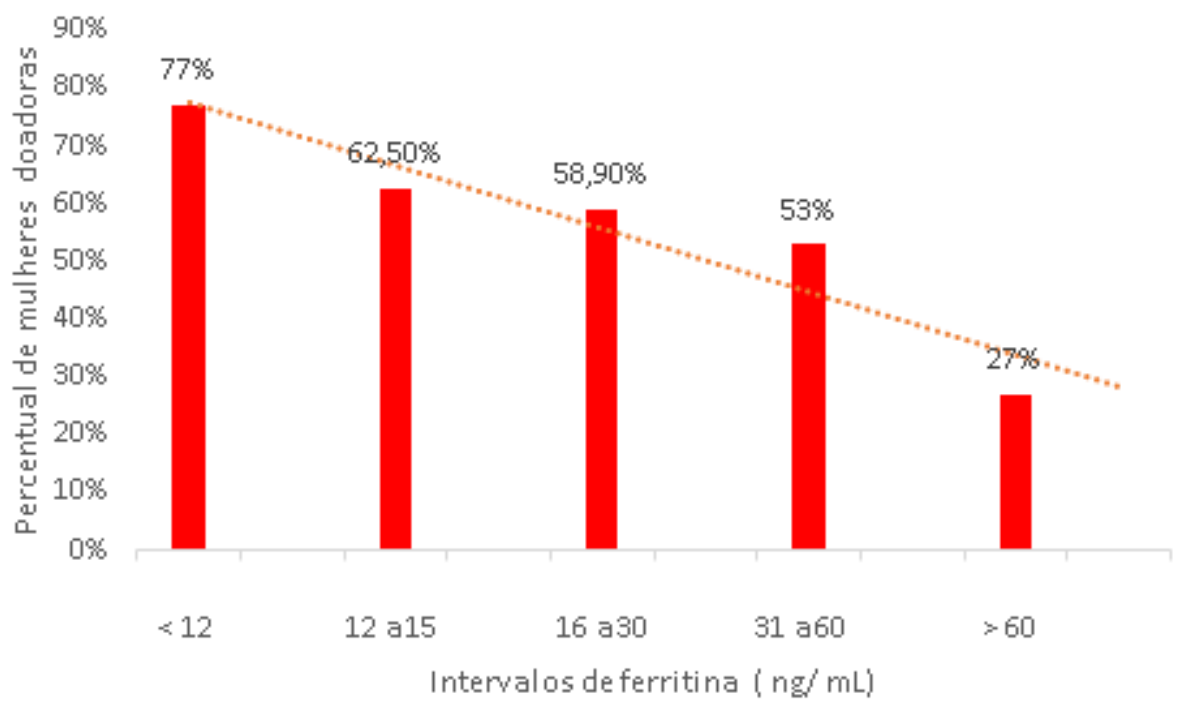

FONTE: A Autora, 2019 


\section{DISCUSSÃO}

É relativamente alta a prevalência de doadores de sangue com baixa reserva de ferro, cerca de $15 \%$. A despeito do homem doar mais frequentemente que a mulher, ainda assim ele apresenta menor depleção de ferro, observou-se que a depleção de ferro em mulheres é 100\% maior. A depleção de ferro pode ser um risco para a saúde de doadores, principalmente de mulheres (NEWMAN,2006).

Nesse estudo, na avaliação do histórico de doações correlacionando com valores de hemoglobina, não foram observadas diferenças significativas em relação a concentração de hemoglobina, independentemente da quantidade de doações ou interrupção por anemia, em nenhum dos sexos. A análise de ferritina sérica está em consonância com Rosvisk et al. (2009), que realizaram um estudo com 893 primodoadores, onde 563 (63\%) eram mulheres e 330 (37\%) eram homens. Com intuito de acompanhar as variações de ferro no organismo do doador ao longo de um ano, observaram que praticamente não houve variações significativas nos valores de hemoglobina para os participantes; no entanto a comparação entre os níveis de ferritina da primeira e quarta coleta demonstrou queda tanto em homens como em mulheres, sendo mais acentuado no último grupo, conforme demonstrado no gráfico 6. Da mesma forma na Austrália, 32,5\% das mulheres que doaram três vezes em um ano, apresentaram depleção de ferro (SALVIN et al, 2014).

Gráfico 6 - Representação das frequências dos participantes do estudo em relação à concentração de hemoglobina e ferritina sérica.

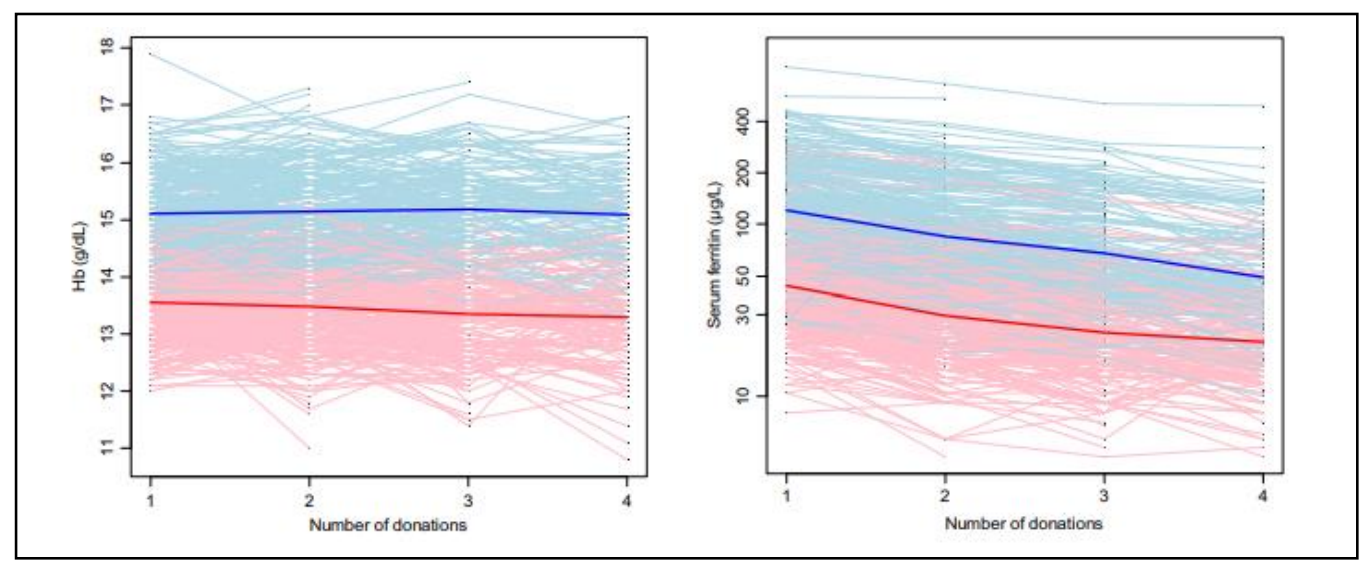

FONTE: Rosvik et al. (2009). 
Foi apontado por esse estudo que mulheres acima de 50 anos apresentaram maior concentração de ferritina, provavelmente na pós menopausa, de acordo com o gráfico 7.

Gráfico 7 - Representação das frequências das participantes do estudo do sexo feminino de acordo com a idade e a concentração de ferritina encontrada.

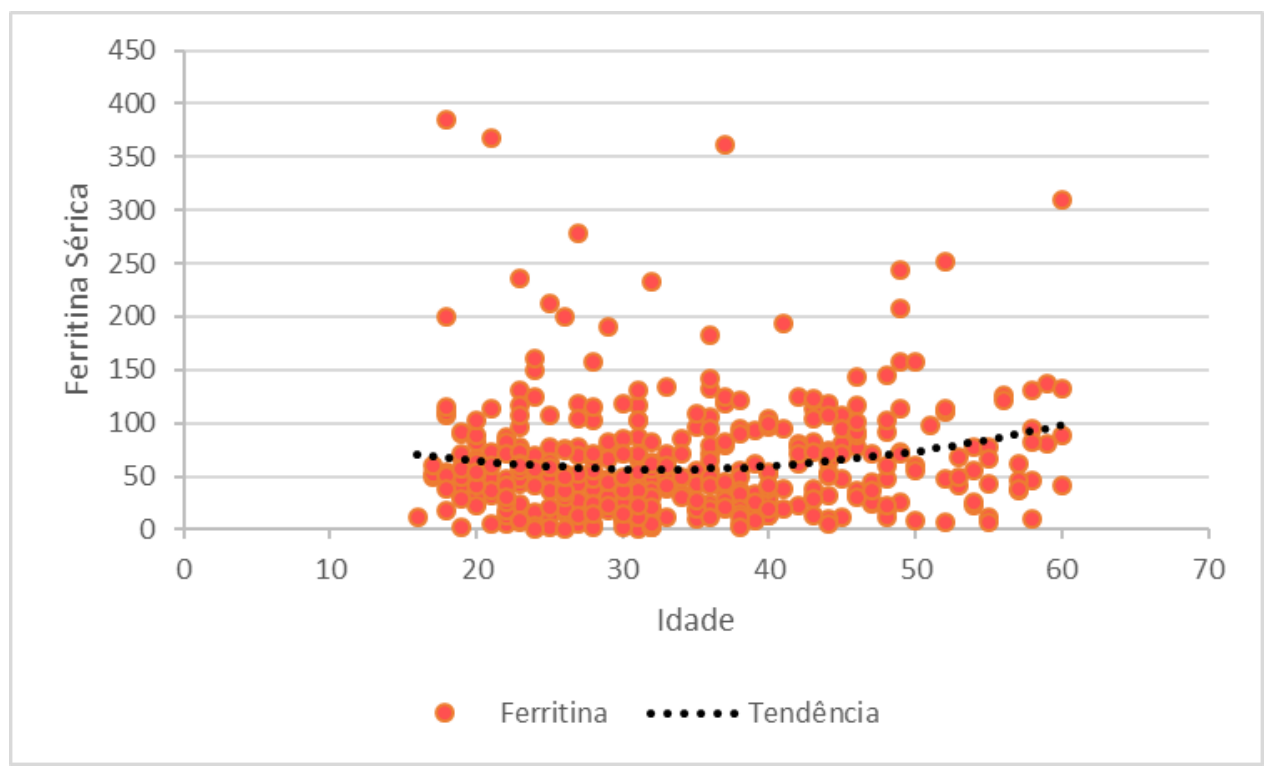

FONTE: A Autora, 2019

Esses resultados coincidiram com estudos de Cable et al (2016) e Kiss et al (2017), que demonstraram que a quantidade de ferro no organismo varia de acordo com o sexo e a idade (gráfico 8).

Gráfico 8 - O ferro armazenado em comparação com a perda da doação de uma unidade de sangue total relatada pelos estudos indicados por Cable et al em 2016 e Kiss et al em 2017

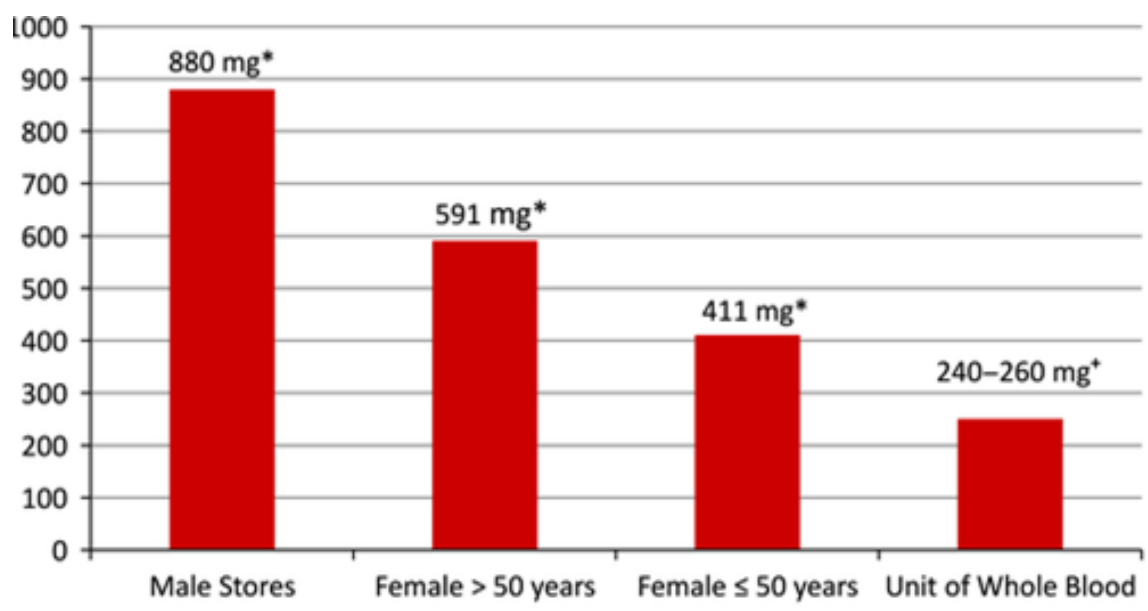


O estudo de Rigas et al (2014), abordou a influência de vários agentes nos níveis de ferro dos doadores de sangue, como menstruação, estilo de vida e dieta, e confirmou que os índices de ferritina nas mulheres na pós-menopausa eram maiores que em mulheres na pré-menopausa. A ferritina é uma proteína de fase aguda, ou seja, seus níveis estão aumentados em doenças inflamatórias e infecciosas, quando então perde a correlação com a reserva de ferro. No entanto, esse fenômeno não deve ter afetado os resultados, pois os doadores de sangue são considerados pessoas com boa saúde (SCHRIER,2014; KISS,2015).

No presente estudo mulheres que relataram ingesta de carne bovina inferior a 5 porções por semana apresentaram dosagem de ferritina sérica menor. Dependendo dos fatores dietéticos, os resultados quanto à depleção de ferro serão distintos. Enquanto um estudo realizado no serviço de Hemoterapia do Hospital Israelita Albert Einstein em 1994 (São Paulo) encontrou apenas 2\% de doadores com depleção de ferro, em outro estudo na mesma cidade, porém com doadores com classe social diferenciada do Hemocentro da Santa Casa de São Paulo, realizado em 1999, evidenciou que $11 \%$ dos doadores apresentaram deficiência de ferro (MOUSINHO RIBEIRO 2008). A ingestão de carne vermelha colabora positivamente com as reservas de ferro, o que foi demonstrado no estudo de Rigas et al (2014) onde um terço dos doadores vegetarianos tinham deficiência de ferro. O ferro heme é encontrado na carne bovina, suína, peixe e aves e corresponde a aproximadamente $40 \%$ do ferro no organismo e os outros $60 \%$ são ferro não heme, encontrados em vegetais. Apesar do ferro não heme estar em maior quantidade o ferro heme é melhor absorvido pelo organismo (ANDREWS,2007).

$\mathrm{Na}$ Índia, a anemia é altamente prevalente devido à deficiência de ferro por questões nutricionais, infecção por vermes e perda de sangue. Um estudo realizado na cidade de Surat, evidenciou que $15 \%$ dos doadores do sexo masculino e $44 \%$ do sexo feminino, apresentavam anemia e apenas $10 \%$ dos doadores consumiam dieta não vegetariana, e não houve diferença entre os grupos que consomem carne e os que não consomem (MAHIDA,2008).

Quanto à suplementação de ferro, no presente estudo observou-se que não houve alterações consideráveis para doadores que fizeram suplementação de vitaminas ou ferro, tanto do sexo masculino como do sexo feminino. Para Rigas et 
al (2014) o fator que menos interferiu no estudo foi o uso de suplementação vitamínica ou ferro, com baixa relevância nos índices hematimétricos ou de ferritina, ao contrário da ingestão de vinho, que estava diretamente proporcional à produção de ferritina. Doadores com ingesta frequente de vinho, apresentaram maiores estoques de ferro tanto homens como em mulheres pós menopausa, coincidindo com esse estudo.

Em 2013, um estudo realizado no Teerã com 117 homens com idade entre 30 e 60 anos, coletou diversos dados para correlacionar com a depleção de ferro, dentre eles IMC, idade, pressão arterial e temperatura corporal, e nenhum desses fatores obteve resultados significantes (MOGHADAM, 2013). No entanto, nesse estudo o IMC dos doadores do sexo masculino teve significância $p<0,05$, quanto maior o IMC maior a dosagem de ferritina sérica.

Nesse estudo cerca de $19 \%$ dos doadores doaram pela primeira vez e aproximademente $15 \%$ apresentavam depleção de ferro sem quaisquer outros fatores associados. (Gráfico 9). Desse grupo de doadores 75\% eram mulheres e não foram encontrados fatores de relevantes de depleção de ferro, como, alimentação, hipermenorreia, múltiplas gestações ou doenças e uso de medicamentos associado.

Gráfico 9 - Representação das frequências dos participantes quanto ao número de doações.

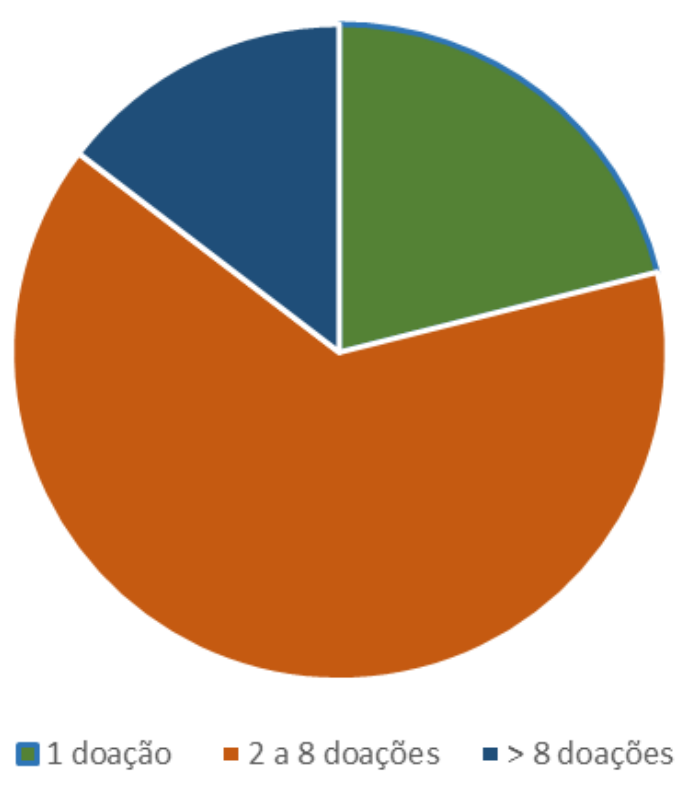

FONTE: A Autora, 2019

Utilizando os mesmos parâmetros que Vries (1958) e os comparando, observa-se que no passado as mulheres doavam mais que os homens e o número 
de doadores fidelizados também eram três vezes maior que o atual, principalmente pela questão cultural da época, onde familiares tinham dever moral de doar sangue para seus familiares (Tabela 23). O estudo de Vries ocorreu com intuito de ampliar um estudo realizado anteriormente pela Cruz Vermelha que evidenciou em um grupo de 32 doadores que 19\% apresentaram um aumento da capacidade insaturada de ligação do ferro, associado a uma diminuição da saturação de ferro, indicando sideropenia latente visto que apresentavam hemoglobina normal. A investigação foi alargada por Vries para o número de 297 doadores com o intuito de investigar se realmente a doação de sangue traria riscos ao doador, e em caso positivo, se esses riscos poderiam ser minimizados ou evitados, e propor novas rotinas preventivas para depleção de ferro.

Tabela 23 - Doadores por número de doações e sexo do estudo Vries (1958)

\begin{tabular}{ccccc}
\multicolumn{5}{c}{ VRIES 1958 } \\
\hline Grupo & N $^{0}$ de doacöes & N $^{0}$ de doadores & Masculino & Feminino \\
\hline I & Primeira & 84 & 30 & 54 \\
II & 1 a 4 & 60 & 21 & 39 \\
III & 5 a 9 & 61 & 31 & 30 \\
N & $>10$ & 92 & 37 & 55 \\
& Total & 297 & 119 & 178 \\
\hline
\end{tabular}

FONTE: Adaptado Vires,1958; Autora, 2019.

Vries, no seu estudo, considerou que a sideropenia latente era de menor importância em homens, sendo exatamente o contrário para as mulheres, e ainda que os exames solicitados isoladamente eram insuficientes para determinar a depleção de ferro. $E$ homens que doaram frequentemente não tiveram seu metabolismo de ferro afetado, diferentemente das mulheres, onde $21,8 \%$ apresentaram aumento do UIBC (Tabela 24), e fez as seguintes considerações para as doadoras de sangue: investigar a histórico ginecológico e gestacional, período de lactação, .e ainda limitação de doação para as mulheres de uma vez ao ano, visto que considerou que aumentando de 6 para 12 meses o intervalo de doações, a perda de sangue por ano para a mulher seria mais ou menos próxima da do doador do sexo masculino, pois um homem doando duas vezes por ano teria uma perda de ferro estimada $450 \mathrm{mg}$, já a mulher doando uma única vez teria uma perda de $550 \mathrm{mg}$, considerando a doação e as perdas por ciclo menstrual, em média 25 mg de ferro/ ciclo (VRIES, 1958). 
Tabela 24 - Resultado dos exames laboratoriais realizados no estudo de Vries. ${ }^{1}$

\begin{tabular}{|c|c|c|c|c|c|c|c|c|c|c|c|}
\hline \multirow{3}{*}{ Grupos } & \multirow{2}{*}{ № de doações } & \multicolumn{2}{|c|}{ Hemoglobina $(\mathrm{g} / \mathrm{mL})$} & \multicolumn{2}{|c|}{ Hematócrito } & \multicolumn{2}{|c|}{$\begin{array}{l}\text { Ferro sérico } \\
(\mu \mathrm{g} / 100 \mathrm{~mL})\end{array}$} & \multicolumn{2}{|c|}{ U.I.B. $C^{*}(\mu \mathrm{g} / 100 \mathrm{~mL})$} & \multicolumn{2}{|c|}{ Saturação de ferro } \\
\hline & & $<11.1$ & $<10.4$ & $<40 \%$ & $<37 \%$ & & & $<280$ & $<300$ & $<30 \%$ & $<27 \%$ \\
\hline & & $M$ & $\mathrm{~F}$ & $M$ & $\mathrm{~F}$ & $M$ & $\mathrm{~F}$ & $M$ & $\mathrm{~F}$ & $M$ & $\mathrm{~F}$ \\
\hline I & Primeira & 1 & 0 & 1 & 0 & 0 & 1 & 1 & 2 & 3 & 6 \\
\hline II & 1 a 4 & 0 & 1 & 0 & 0 & 0 & 1 & 0 & 1 & 1 & 6 \\
\hline III & 5 a 9 & 1 & 2 & 0 & 1 & 0 & 1 & 0 & 0 & 6 & 3 \\
\hline IV & $>10$ & 3 & 3 & 1 & 2 & 2 & 7 & 12 & 6 & 6 & 19 \\
\hline
\end{tabular}

FONTE: Adaptado Vires,1958.

Apesar do estudo atual e o de Vries utilizarem parâmetros distintos para evidenciarem a depleção de ferro, em ambos estudos é evidente a perda de ferro pós doação, principalmente em mulheres.

De uma maneira geral, esse estudo identificou depleção de ferro em doadores de sangue do sexo feminino com idade entre 18 e 45 anos assim como os estudos de Cable et al $(2012 ; 2016)$ demonstraram prevalência aumentada de depleção de ferro em doadores fidelizados e de repetição, especialmente em mulheres mais jovens. Em um estudo realizado em Manaus em 2002, com 528 doadores, tendo como 215 doadores de primeira vez, $7 \%$ desses doadores apresentavam ferritina inferior a $20 \mathrm{ng} / \mathrm{L}$, os autores concluíram que a depleção por ferro ocorreria em doadores de repetição, principalmente a partir da quinta doação. (PASSOS et al, 2005)

O presente estudo evidenciou que mulheres que menstruam tem maior depleção de ferro em relação as que não menstruam $(p<0,05)$, e as mulheres que apresentam hipermenorréia apresentam mais depleção ainda. A mesma relevância foi observada em mulheres multíparas, quanto maior o número de filhos maior a depleção. As mesmas evidências foram encontradas por Cable et al (2012): hipermenorréia e mulheres multíparas apresentaram níveis de ferritina inferiores aos de mulheres pós menopausa.

\footnotetext{
${ }^{1}$ Os níveis de hemoglobina foram determinados utilizando o colorímetro fotoelétrico da Evans Electroselenium. O hematócrito foi medido em tubos de hematócrito pela técnica de Wintrobe. A determinação do ferro sérico foi realizada pelo método da ortofenantrolina (Heilmeyer e Plocner.) U.I.B.C = capacidade insaturada de ligação do ferro foi medida pelo método de Rath e Finch. Como o ferro sérico adicionado à capacidade insaturada de ligação do ferro produz um valor que é conhecido como a capacidade total de ligação do ferro, a saturação do ferro foi calculada a partir da fórmula: ferro sérico saturação de ferro X 100 (por cento).
} 
O estudo apresentou como ponto forte a disponibilidade de um grande número de doadores participando da pesquisa, a variabilidade de fatores relacionados com a diminuição de estoque de ferro terem sido arguidos e a dosagem de ferritina nos doadores. Porem, o estudo foi limitado quando das comparações com outras instituições e outras pesquisas, visto que se trata de perfil sócio econômico e geográfico distinto. Outro fator é que cada autor consultado considera a faixa de depleção de maneira diferente.

Poderia ter sido levado em conta também a ingestão de café pelos doadores. A população atendida, além de consumir uma grande quantidade de leite e derivados, nesse estudo $91 \%$ dos participantes ingerem leite e derivados com regularidade, o que pode inferir na absorção do ferro, também consomem café. 
Na população estudada, $15 \%$ dos doadores que doaram pela primeira vez apresentaram depleção de ferro, dos quais $75 \%$ eram mulheres.

No caso dos doadores de repetição com depleção de ferro, $65 \%$ eram mulheres.

O histórico de doações, fatores dietéticos, hábitos como uso de álcool e tabaco, histórico ginecológico, doenças pré-existentes e medicamentos utilizados, não apresentaram resultados significantes.

Considerando que mulheres em idade fértil constituem um grupo de risco para depleção de ferro, e que as triagens clínica e hematológicas não suficientes para detectar, talvez mereçam algum grau de suplementação de ferro, que poderá ser avaliado em um estudo futuro. 
AABB. AABB Hemovigilance. Disponível em:

$<$ http://www.aabb.org/research/hemovigilance/Pages/default.aspx> Acesso em: 07 fev.2019.

AABB. National Blood Fundation. Disponível em:

<http://www.aabb.org/research/nbf/Pages/default.aspx> Acesso em: 07 fev.2019.

AGHA, F.; KHAN, R. Ferritin levels in professional blood donors. JAMA, v. 39, p. 124-126. 1989.

ALKHATEEB, A. A., CONNOR, J. R. (2013). The significance of ferritin in cancer: Anti-oxidation, inflammation and tumorigenesis. Biochimica et Biophysica Acta (BBA) - Reviews on Cancer, 1836(2), 245-254.

ANDREWS, N. C.; SCHMIDT, P. J. Iron Homeostasis. 2007. Annual Review of Physiology, 69(1), 69-85.

BAART, A. M. et al. High prevalence of subclinical iron deficiency in whole blood donors not deferred for low hemoglobin. Transfusion. v. 53, n. 8, p. 16707. 2013.

BIRGEGARD, G. et al. High incidence of iron depletion and restless leg syndrome (RLS) in regular blood donors: intravenous iron sucrose substitution more effective than oral iron. Vox Sang, v. 99, p. 354-61. 2010.

BORDIN, Jos; LANGHE JUNIOR, Dante Mário; COVAS, Dimas Tadeu. Fundamentos de Hemoterapia. São Paulo: Atheneu, 2007.

BOULTON, F.; COLLINS, D.; INSKIP, H. A study of the iron and HFE status of blood donors, including a group who failed the initial screen for anemia. $\mathrm{Br} \mathrm{J}$ Hematolol, v. 108, n. 2, p. 434-439. 2000.

BRANDINO, B. A. et al. A incidência de redução do estoque de ferro, ferritina e hemoglobina em doadores de sangue. Centro de Medicina Laboratorial de Limeira. Irmandade de Misericórdia da Santa Casa de Limeira - SP, 2007.

BRASIL. Agência Nacional de Vigilância Sanitária. Marco Conceitual e Operacional de Hemovigilância. Guia para a Hemovigilância no Brasil. Brasília, DF, 2015.

BRASIL. Ministério da Saúde. Saúde reforça campanha para incentivar doação de sangue. Disponível em: <http://www.saude.gov.br/noticias/agenciasaude/44728-saude-reforca-campanha-para-incentivar-doacao-de-sangue>. Acesso em: 12 jun. 2019

BRINGHENTI, C. Alterações nos níveis de ferritina e transferrina e sua relação com doença hepática. 2011. Trabalho de Conclusão de Curso (Graduação em Farmácia) - Universidade do Extremo Sul Catarinense, Santa Catarina, 2011. 
BRITTENHAM, G. M. Disorders of iron metabolism: Iron deficiency and overload. In: Hematology Basic Principles and Practice, 2nd ed, Hoffman, R, Benz, EJ Jr, Shattil, SJ, et al (Eds), Churchill Livingstone, New York, 1995.

BRITTENHAM, G. M.; SHETH, S. Genetic Disorders Affecting Proteins Of Iron Metabolism: Clinical Implications. Annu Rev Med. v. 51, p. 443-64. 2000.

CABLE, R. G. et al. NHLBI Retrovirus Epidemiology Donor Study-II (REDS-II). Iron deficiency in blood donors: the REDS-II Donor Iron Status Evaluation (RISE) study. Transfusion, v. 52, n. 4, p. 702-11. 2012.

CABLE, R. G., et al. (2016). Effect of iron supplementation on iron stores and total body iron after whole blood donation. Transfusion, 56(8), 2005-2012

CANÇADO, R. D. et al. Iron deficiency in blood donors. Rev Paul Med, v. 119, n. 4, p. 132-1354. 2001.

CANÇADO, R. D., et. al. Avaliação laboratorial da deficiência de ferro em doadoras de sangue. Revista Brasileira de Hematologia e Hemoterapia, 29(2): 153-159. 2007.

DAWSON, B.; TRAPP, R. G. Bioestatística: Básico e Clínica. $3^{\underline{a}}$ ed. Ed. Mac Graw-Hill. 2003.

ERIKSSON, E. A. et al. Iron depletion in blood donors - Have extended erythrocyte and reticulocyte parameters diagnostic utility? Transfus Apher Sci, v. 53, n. 1, p. 76-81. 2015.

FERNANDES, R. A. F. et al. Investigação laboratorial do paciente com anemia microcítica. In: ERICHSEN, Elza Santiago et al (org.). Medicina laboratorial para o clínico. 1. ed. Belo Horizonte: Coopmed, 2009. v. unico, cap. 24, p. 263 - 275.

FIGUEIREDO, Maria Stella; ZAGO, Marco Antonio. Metabolismo do Ferro. In: ZAGO, Marco Antonio; FALCÃO, Roberto Passeto; PASQUINI, Ricardo (ed.). Tratado de Hematologia. 1ª . ed. São Paulo: Atheneu, 2013. v. único, cap. 19, p. 137-144.

$\mathrm{FINCH}, \mathrm{C}$. A. et al. Effect of blood donation on iron stores as evaluated by serum ferritin. Blood, v. 50, n. 3, p.441-447. 1977

FISBERG, M. et al. Funções Plenamente Reconhecidas de Nutrientes Ferro, 2008. Disponível em < http://ilsi.org/brasil/wpcontent/uploads/sites/9/2016/05/03-Ferro.pdf > Acesso em 07 fev.2019.

FUNDAÇÃO HEMOMINAS. Unidade de Coleta e Transfusão. Disponível em $<$ http://www.hemominas.mg.gov.br/unidades-e-contratantes/rede-

hemominas/unidade-de-coleta-e-transfusao>. Acesso em> 07 fev. 2019.

GALHARDI, C. M. et al. Relação dos números de auxílios-doença previdenciários para trabalhadores de doenças relacionadas aos transtornos mentais e comportamentais e o absenteísmo. In: Oliveira SFP, et al. AIMES nas trilhas da cartografia do conhecimento acadêmico. 2018. p. 
657-664.

GROTTO, H. Z. W. Fisiologia e metabolismo do ferro. Rev Bras Hematol Hemoter, v. 32, n. S2, p. 08-17. 2010.

GUALANDRO, S. F. M. et al. Deficiência de ferro em doadoras de sangue da Fundação Pró-sangue/Hemocentro de São Paulo. Ser Monogr Esc Bras Hematol. 1999.

ISBT. History of the International Society of Blood Transfusion. Netherlands, 12 jun. 2019. Disponível em: >https://www.isbtweb.org/about-isbt/history/>. Acesso em: 12 jun. 2019.

KELL, D. B.; PRETORIUS, E. Serum ferritin is an important inflammatory disease marker, as it is mainly a leakage product from damaged cells.2014. Metallomics, 6(4), 748-773.

KESSLER, D. et al. Donor deferrals by medical history (abstract). Transfusion, v. 39, p. 33S. 1999.

KISS, J.E. Laboratory and genetic assessment of iron deficiency in blood donors. Clinics in Laboratory Medicine. 2015. 35 , 73-91.

KISS, J.E. et al. Oral iron supplementation after blood donation: a randomized clinical trial. 2015. JAMA,313, 575-583.

KISS, J.E. et al.Quantification of body iron and iron absorption in the REDS-II Donor Iron Status Evaluation (RISE) study. 2017. Transfusion ,57,1656-1664.

KISS, J. E., VASSALO,R. R. How do we manage iron deficiency after blood donation? 2018. British Journal of Haematology, 181(5), 590-603.

LIPSCHITZ, D. A. et al. A clinical evaluation of serum ferritin as an index of iron stores. N Engl J Med, v. 290, p. 213-216. 1974.

LUKUSA, F. N. et al. Iron deficency and anemia among donors in Kinshassa. Pan Afr Med J. v. 13, n. 23, p. 174. 2016.

MAHIDA VI, BHATTI A, GUPTE SC. Iron status of regular voluntary blood donors. Asian J Transfus Sci 2008;2:9-12

MIOT, H. A. Tamanho da amostra em estudos clínicos e experimentais. J Vasc Bras. v. 10, n. 4. 2011.

MOGHADAM, A. M. et al. Relationship between blood donors' iron status and their age, body mass index and donation frequency. 2013. Sao Paulo Medical Journal, 131(6), 377-383.

MOUSINHO-RIBEIRO, R. C. et al. Impacto da doação de sangue nos depósitos de ferro do organismo de doadores. 2008. Rev. Bras. Hematologia e Hemoterapia. vol.30, n.1, pp.62-64. 
carenciais. In: NAOUM, Flávio Augusto (ed.). Doenças que alteram os exames hematológicos. 1a. ed. São Paulo: Atheneu, 2010. v. único, cap. 1, p. 3-11.

NEWMAN, B. Iron depletion by whole-blood donation harms menstruating females: the current whole-blood-collection paradigm needs to be changed. Transfusion, v. 46, p. 1667-81. 2006.

PASRICHA, S.R., et. Al. Postdo-nation iron replacement for maintaining ironstores in female whole blood donors in routinedonor practice: results of two feasibility studiesin Australia. 2017. Transfusion, 57, 1922-1929.

PASSOS, L. N. M.et al. Sideropenia sem anemia em doadores de sangue do Hemocentro do Amazonas - Hemoam. Revista Brasileira de Hematologia e Hemoterapia, 27(1).2005

PATEL, E.U. et al. Association of blood donation with iron deficiency among adolescent and adult females in the United States: a nationally representative study. Blood Donors and Blood Collection (Editorials). Transfusion. p. 1613- 1616. 2019.

POPOVSKY, M. A. Anemia, depleção de ferro e doador de sangue: é hora de trabalhar em nome do doador. Transfusion, v. 52, n. 4, p. 688-92. 2012.

POTTGIESSER, T., Specker et al.Recovery of hemoglobin mass after blood donation. Transfusion, 48(7), 1390-1397. 2008.

RAZALI, M.; NORNADIAH \& YAP, B. Power Comparisons of Shapiro-Wilk, Kolmogorov-Smirnov, Lilliefors and Anderson-Darling Tests. J. Stat. Model. Analytics. 2011.

RIGAS, A. S. et al. Predictors of iron levels in 14,737 Danish blood donors: results from the Danish Blood Donor Study. 2014. Transfusion, 54(3pt2), 789796.

ROSA, K. P. S. Efeitos Da Fisioterapia Aquática E Convencional Sobre A Marcha, Aspectos Clínicos E Funcionais De Sujeitos Com Estenose De Canal Lombar: ensaio clínico randomizado. [Dissertação]. UNIVERSIDADE FEDERAL DO RIO GRANDE DO SUL. Porto Alegre, 2016.

ROSVIK, A.S.,et al.The effect of blood donation frequency on iron status. Transfus Apher Sci. 2009; 41:165-169.

SALVIN, H.E. et al. Iron deficiency in blood donors: a national cross-sectional study. Transfusion 2014; 54: 2434-44.

SCHRIER, S. L. Causes and diagnosis of iron deficiency anemia in the adult. Uptodate Internet. 2014.

SHOT - Serious Hazard Of Transfusion. Disponível em: <https://www.shotuk.org/> Acesso em: 07 fev.2019.

SILVA, B.; FAUSTINO, P. (2015). An overview of molecular basis of iron metabolism regulation and the associated pathologies. Biochimica et 
Biophysica Acta (BBA) - Molecular Basis of Disease, 1852(7), 1347-1359.

SIMON, T. L. et al. Iron stores in blood donors. J Am Med Assoc, v. 245, p. 20382043. 1981.

SKIKNE, B et al.Iron and blood donation. Clin Haematol 1984; 13:271-87.

SPENCER B. R. et al. Elevated risk for iron depletion in high-school age blood donors, Transfusion. v. 59, n. 5, p. 1706-1716. 2019.

UBIALI, Eugênia Maria Amorim. Doadores de sangue. In: COVAS, Dimas Tadeu ; UBIALI, Eugenia Maria Amorim; SANTIS, Gil Cunha De (ed.). Manual de Medicina Transfusional. 2ª ed. São Paulo: Atheneu, 2014. v. único, cap. 2, p. 5-9.

VRIES, S. I. DE; POTTER, E. DE: Studies on iron metabolism in blood donors. Vox Sang, v. 3, p. 392. 1958.

WHO. Blood safety and availability. Genebra, 29 maio 2019. Disponível em: $<$ https://www.who.int/news-room/fact-sheets/detail/blood-safety-and-availability>. Acesso em: 12 jun. 2019. 


\title{
APÊNDICE A - Termo de Consentimento Livre e Esclarecido
}

\author{
TÍTULO DO PROJETO: Sideropenia em doadores de sangue da Unidade da Fundação \\ Hemominas de Poços de Caldas
}

Pesquisadora responsável: Cibele Angélica de Souza Spina

Contato: Telefone: 03521019302 e-mail: cibele.angelica@hemominas.mg.gov.br

Instituição responsável e local da coleta de dados: Unidade da Fundação Hemominas de Poços de Caldas. Localizada à avenida José Remígio Prézia ํo 303

Jardim dos Estados - Poços de Caldas - MG Telefone: 03521019300

Instituição responsável pela execução dos exames: Laboratório da Policlínica Central Secretaria Municipal de Saúde de Poços de Caldas, localizado à avenida Francisco Salles, n1155, Centro - Poços de Caldas - MG - telefone: 0353697 5371, tendo como contato o Secretário Municipal de Saúde Flávio Togni Lima e Silva.

Estamos realizando uma pesquisa, junto aos doadores de sangue da Unidade da Fundação Hemominas de Poços de Caldas, com intuito de verificar se há correlação entre o número de doações de sangue, alterações no hemograma e nos níveis de ferritina. A ferritina é uma proteína responsável pelo armazenamento do ferro no organismo. Para você melhor compreender, o ferro é muito importante na prevenção da anemia. O motivo que nos leva a estudar a temática proposta é trazer maior segurança no processo da doação. Se você aceitar participar desta pesquisa, estará contribuindo para realização de um estudo muito importante para a segurança dos doadores de sangue.

Para este estudo adotaremos os seguintes procedimentos: antes da doação será aplicado pelo triagista um questionário para detalhar hábitos alimentares, uso de medicamentos, presença de patologias, quantidade de doações anteriores, e observações que forem necessárias. Durante a coleta da bolsa de sangue, ao serem coletadas as amostras de rotina, será acrescida uma amostra de sangue de $2 \mathrm{~mL}$ para execução do exame de ferritina. Essas amostras ficarão depositadas no biorrepositório localizado na sala de armazenamento de hemocomponentes e amostras da Unidade da Fundação Hemominas de Poços de Caldas até o término da pesquisa, quando serão imediatamente descartadas. Pedimos a sua autorização para a coleta, 0 depósito, 0 armazenamento, a utilização e descarte de sangue. A utilização do seu material biológico está vinculada somente a este projeto de pesquisa.

Os resultados desta pesquisa serão mantidos sob absoluto sigilo e sua privacidade será preservada. As doações anteriores serão consultadas pela pesquisadora através do sistema HEMOTE (sistema de softwares que armazenam as informações dos doadores no âmbito da Fundação Hemominas) para verificar valores anteriores de hemoglobina e ou hematócrito. Para garantir a rastreabilidade de acesso a essas informações, o sistema HEMOTE possui níveis de acesso, é acessado por senha pessoal e intransferível com registro dos acessos por usuário, visando manter a confidencialidade das informações do doador.

O material usado na coleta do sangue é descartável e você não corre risco de contaminação ou qualquer outro tipo de dano ou risco à sua saúde, porém você tem o direito de pedir uma indenização por qualquer dano que resulte da sua participação no estudo.

A sua participação é voluntária e a recusa em participar não acarretará qualquer penalidade ou modificação na forma em que é atendido pelo pesquisador.

Os resultados do exame coletado, ferritina, estará disponível na unidade a partir de 30 dias após a coleta, e poderá ser consultado a qualquer momento durante o horário de atendimento, pelo pesquisador. No caso de alterações em quaisquer exames, você será comunicado através de convocação para comparecer na unidade e será atendido pela pesquisadora responsável. Havendo correlação clínica com os resultados obtidos, você será encaminhado para a unidade básica de saúde de referência para diagnóstico, tratamento e acompanhamento ambulatorial, de forma gratuita e pelo tempo que se fizer necessário., conforme fluxo já existente na unidade.

Os resultados individuais dos exames laboratoriais desta pesquisa serão mantidos sob absoluto sigilo e sua privacidade será preservada. As informações desta pesquisa serão confidencias e serão divulgadas apenas em eventos ou publicações científicas, não havendo identificação dos participantes, a não ser entre os responsáveis pelo estudo, sendo assegurado o 
sigilo sobre sua participação.

Este termo de consentimento encontra-se impresso em duas vias, sendo que uma será arquivada pelo pesquisador responsável, na Unidade da Fundação Hemominas de Poços de Caldas e a outra via ficará com você. Em caso de divulgação dos resultados da pesquisa preservaremos o anonimato dos participantes (o nome do doador não será revelado).

Sua participação nesta pesquisa é voluntária e você pode interrompê-la a qualquer momento. Qualquer procedimento diferente do que até aqui afirmamos será antes exposto a você e sujeito ao seu consentimento.

A qualquer momento você poderá obter esclarecimento com a pesquisadora supracitada, sobre o estudo em qualquer aspecto que desejar e estará livre para participar ou recusar-se a participar, podendo retirar, a qualquer momento, o seu consentimento de guarda e utilização do material biológico armazenado no biorrepositório.

Caso você tenha qualquer dúvida quanto aos seus direitos como participante de pesquisa, entre em contato com Comitê de Ética em Pesquisa da Fundação Hemominas em (31) 3768-4587, Alameda Ezequiel Dias 321 - Santa Efigênia - Belo Horizonte - Minas Gerais. CEP 30130-110 , email: secretaria.pesquisa@hemominas.mg.gov.br, de segunda a sexta-feira das 8h às 17h. $O$ Comitê de Ética é um órgão independente constituído de profissionais das diferentes áreas do conhecimento e membros da comunidade. Sua responsabilidade é garantir a proteção dos direitos, a segurança e o bem-estar dos participantes por meio da revisão e da aprovação do estudo, entre outras ações.

\section{CONSENTIMENTO PÓS INFORMADO}

Declaro para fins desta pesquisa clínica que fui esclarecido sobre seu objetivo e que concordo em participar dela voluntariamente, me sentindo livre para recusar ou retirar o meu consentimento em qualquer momento.

Nome:

Endereço:

Assinatura:

Data:

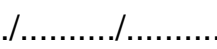

Identificação da bolsa: 


\section{APÊNDICE B - Questionário}

\begin{tabular}{|c|c|c|c|c|}
\hline \multicolumn{4}{|c|}{$\begin{array}{l}\text { PESQUISA: SIDEROPENIA EM DOADORES DE SANGUE DA } \\
\text { UNIDADE DA FUNDAÇÄO HEMOMINAS DE POÇOS DE CALDAS } \\
\text { QUESTIONÁRIO }\end{array}$} & \multirow{4}{*}{$\begin{array}{c}\text { ESPAÇO DESTINADO PARA AFIXAR } \\
\text { ETIQUETA DE IDENTIFICAÇÃO DO } \\
\text { DOADOR }\end{array}$} \\
\hline \multicolumn{4}{|c|}{ IDENTIFICAÇÄO DO DOADOR } & \\
\hline \multicolumn{4}{|c|}{ NOME COMPLETO (SEM ABREVIATURAS): } & \\
\hline $\begin{array}{c}\text { SEXO: } \square \text { MASCULINO } \\
\square \text { FEMININO }\end{array}$ & $\begin{array}{l}\text { IDADE } \\
\text { (anos): }\end{array}$ & \begin{tabular}{|l} 
PESO \\
(Kg):
\end{tabular} & $\begin{array}{l}\text { ALTURA } \\
(\mathrm{cm}):\end{array}$ & \\
\hline \multicolumn{5}{|c|}{ IDENTIFICAÇÃO DO DOADOR } \\
\hline
\end{tabular}

1. É a sua primeira doação de sangue? $\square$ SIM $\square$ NÃO

2. Você já doou sangue em outra instituição? $\square$ SIM $\quad \square$ NÃo $\quad 3$. Há quanto tempo? $\square \leq 2$ anos $\square>2$ anos

4. Foram doações de: $\square$ sangue total $\square$ hemácias duplas $\square$ plaquetas $\square$ não se aplica

5. Já interrompeu as doações alguma vez por anemia? $\square$ SIM $\square$ NÃO

6. Se sim, quantas vezes? _ 7. Quando? $\square \leq 2$ anos $\square 2$ a 5 anos $\square>5$ anos

ALIMENTAÇÄO

8. Com que frequência você come carne (qualquer tipo) na semana, em número de refeições?

$\square$ não como carne $\square 1$ a 2 refeições $\square 3$ a 4 refeições $\quad \square 5$ a 9 refeições $\quad \square 10$ a 14 refeições $\square$ mais que 14 refeiçōes

9. Qual tipo de carne você mais come?

$\square$ carne (vaca) $\square$ porco $\square$ frango $\square$ peixe

10. Com que frequência você consome leite e/ou derivados na semana?

$\square$ não consumo $\square 1$ a 2 vezes $\quad \square 3$ a 4 vezes $\quad \square 5$ a 9 vezes $\quad \square 10$ a 14 vezes $\quad \square$ mais que 14 vezes

11. Em qual horário você consome leite e/ou derivados?

$\square$ não consumo $\square$ no café da manhã $\quad \square$ após as refeiçôes $\square$ o dia todo $\square$ a noite

12. Você é vegano? (nesta pesquisa, considere VEGANO como o indivíduo que não ingere nada de origiem animal, como ovos, queijo,leite, mel, etc)
$\square$ SIM
$\square$ NÃO
13. Se sim, desde quando?
$\square \leq 2$ anos
2 a 5 anos
$>5$ anos

14. Você é vegetariano? (nesta pesquisa, considere VEGATARIANO como o indivíduo que não ingere carnes em geral, incluindo aves e peixes).

$\square$ sIM $\quad \square$ NÃo 15 . Se sim, desde quando? $\quad \square \leq 2$ anos $\quad \square 2$ a 5 anos $\quad \square>5$ anos

16. Você consome verduras verde-escuras?

$\square$ SIM $\quad \square$ NÃO

17. Com que frequência você come verduras verde escuras na semana, em número de refeições?

$\square$ não como verdura $\square$ 1 a 2 refeições $\square 3$ a 4 refeiçôes $\square 5$ a 9 refeições $\quad \square 10$ a 14 refeiçōes $\square$ mais que 14 refeições 
18. Está em uso de vitaminas nos últimos 12 meses?

$\square$ sim $\square$ NÃo $\quad$ 19. Se sim, qual?

20. Há quanto tempo? $\square<1$ mês $\square 1$ a 6 meses $\square>6$ meses

\begin{tabular}{|c|c|}
\hline & HÁBITOS \\
\hline $\begin{array}{l}\text { 21. Você consome bebida alcoólic } \\
\text { 22. Se sim, qual frequência? } \\
\text { 23. Você fuma cigarro de papel? } \\
\text { 25. Ex fumante? } \square \text { sim } \square \text { NÃo }\end{array}$ & $\begin{array}{l}\text { ca ? } \square \text { sim } \square \text { NẪo } \\
\square \text { Diariamente } \square \text { Eventualmente } \square \text { Raramente } \square \text { Não bebo } \\
\square \text { sim } \square \text { NÃo } 24 \text {. Se sim, quantos / dia? } \square \leq 10 \quad \square \text { entre 11 e 20 } \square>20 \\
\text { 26. Se sim, há quanto tempo? } \square \leq 12 \text { semanas } \quad \square>12 \text { semanas }\end{array}$ \\
\hline $\begin{array}{c}\text { QUESTÕES } \\
27 \text { A } 32 \\
\text { EXCLUSIVAS } \\
\text { PARA } \\
\text { MULHERES }\end{array}$ & 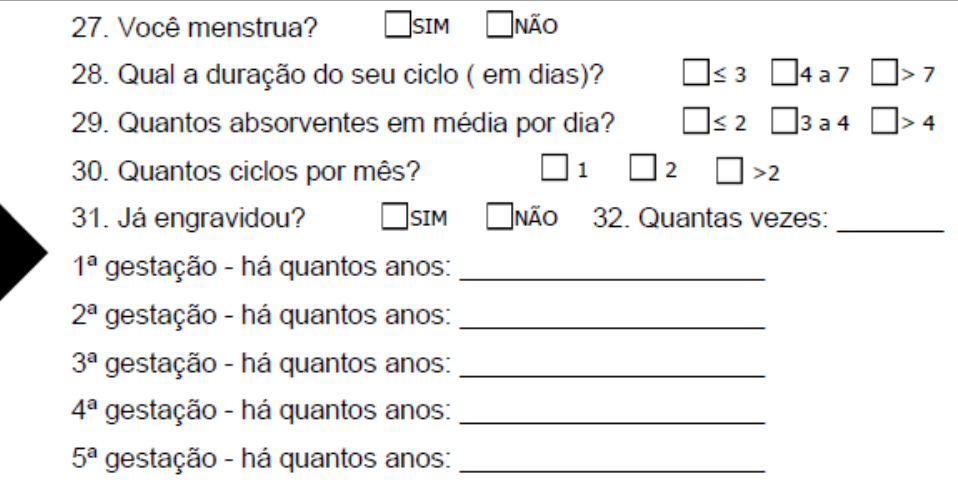 \\
\hline
\end{tabular}

\section{PATOLOGIAS}

33. Já teve anemia antes? $\square$ sIM $\square$ NÃo

34. Se sim, fez tratamento com ferro? $\square$ sIM $\square$ NÃo

\begin{tabular}{|c|c|c|c|c|c|c|c|c|c|}
\hline \multicolumn{8}{|c|}{ PREENCHIMENTO EXCLUSIVO DA PESQUISADORA } & \multicolumn{2}{|c|}{ MATRÍCULA DO DOADOR } \\
\hline \multicolumn{10}{|c|}{ HISTÓRICO DAS DOAÇŐES ANTERIORES } \\
\hline DATA & & LOR & & & & LOR & DATA & VALOR & \\
\hline DOAÇĀO & $\mathrm{HB}$ & JT & DOAÇĀO & 11 & $\mathrm{HB}$ & HT & DOAÇĀO 21 & $\mathrm{HB}$ & HT \\
\hline DOAÇÁO & $\mathrm{HB}$ & HT & DOAÇĀO & 12 & $\mathrm{HB}$ & HT & DOAÇĀO 22 & $\mathrm{HB}$ & HT \\
\hline DOAÇÂOO & $\mathrm{HB}$ & HT & DOAÇÄO & 13 & $\mathrm{HB}$ & HT & DOAÇĀO 23 & $\mathrm{HB}$ & HT \\
\hline DOAÇĀO & $\mathrm{HB}$ & HT & DOAÇÁO & 14 & $\mathrm{HB}$ & HT & DOAÇĀO 24 & $\mathrm{HB}$ & HT \\
\hline DOAÇĀO & HB & HT & DOAÇÁO & 15 & $\mathrm{HB}$ & HT & DOAÇĀO 25 & $\mathrm{HB}$ & HT \\
\hline \begin{tabular}{|ll} 
DOAÇÃO & 6
\end{tabular} & $\mathrm{HB}$ & HT & DOAÇĀO & 16 & $\mathrm{HB}$ & HT & DOAÇĀO 26 & $\mathrm{HB}$ & HT \\
\hline \begin{tabular}{|ll} 
DOAÇÁO & 7
\end{tabular} & $\mathrm{HB}$ & HT & DOAÇĀO & 17 & $\mathrm{HB}$ & HT & DOAÇÄO 27 & $\mathrm{HB}$ & HT \\
\hline
\end{tabular}




\begin{tabular}{|c|c|c|c|c|c|c|c|c|c|c|}
\hline DOAÇĀO & 7 & $\mathrm{HB}$ & HT & DOAÇĀO & 17 & $\mathrm{HB}$ & $\mathrm{HT}$ & DOAÇÁO 27 & $\mathrm{HB}$ & HT \\
\hline DOAÇÁOO & 8 & $\mathrm{HB}$ & HT & DOAÇÁO & 18 & $\mathrm{HB}$ & HT & DOAÇÁO & HB & HT \\
\hline DOAÇÃO & 9 & $\mathrm{HB}$ & $\mathrm{HT}$ & DOAÇÃO & 19 & $\mathrm{HB}$ & HT & DOAÇÄO & $\mathrm{HB}$ & HT \\
\hline DOAÇÁO & 10 & $\mathrm{HB}$ & HT & DOAÇÃO & 20 & $\mathrm{HB}$ & |HT & DOAÇÁO & HB & HT \\
\hline
\end{tabular}

COMORBIDADES RELACIONADAS À DEPLEÇÃO DE FERRO VERIFICADAS NO QUESTIONÁRIO DE TRIAGEM CLINICA:

\begin{tabular}{|l|l|l|}
\hline Uso de medicamentos (inibidores de bomba) & $\square$ AUSENTE $\square$ PRESENTE & Tempo: \\
\hline Sangramento no tubo digestivo: crônicos ou agudos; & $\square$ AUSENTE $\square$ PRESENTE & Tempo: \\
\hline Síndrome de má absorção intestinal & $\square$ AUSENTE $\square$ PRESENTE & Tempo: \\
\hline Doença celiaca & $\square$ AUSENTE $\square$ PRESENTE & Tempo: \\
\hline Epistaxe & $\square$ AUSENTE $\square$ PRESENTE & Tempo: \\
\hline Doenças descamativas da pele & $\square$ AUSENTE $\square$ PRESENTE & Tempo: \\
\hline Doenças respiratórias & $\square$ AUSENTE $\square$ PRESENTE & Tempo: \\
\hline Outros (especificar): & & Tempo: \\
\hline
\end{tabular}




\section{ANEXO A - Regimento Institucional de Biorrepositório}

\section{REGIMENTO INSTITUCIONAL DE BIORREPOSITÓRIO}

O presente regimento estabelece as normas para formação e operacionalização do biorrepositório vinculado ao Projeto de Pesquisa "Sideropenia em doadores de sangue da Unidade da Fundação Hemominas de Poços de Caldas" a ser gerenciado pela pesquisadora Cibele Angélica de Souza Spina com participação da Unidade da Fundação Hemominas de Poços de Caldas, conforme définido na legislação competente, atendendo, em especial, ao disposto na Resolução CNS 441/11 e na Resolução CNS 466/12.

1. O biorrepositório será constituído por:

1.11000 amostras de sangue total destinados ao exame de Ferritina: amostras coletadas em tubo seco com gel separador no mínimo $2 \mathrm{ml}$, identificadas através do sistema ISBT, que serão centrifugadas, analisadas, separadas, e posteriormente enviadas para o laboratorio de apoio - Laboratório da Policlínica Central para realização do exame através do soro, armazenado em tubo tipo EPPENDORF de $2 \mathrm{ml}$ identificado através do sistema IȘBT, e devolvido para a unidade onde será congelado a menos $20^{\circ} \mathrm{C}$ até o término da pesquisa.

2. O biorrepositório será sediado e armazenado no setor de armazenămento de hemocomponentes não liberados e de amostras situado na Unidade da Fundação Hemominas de Poços de Caldas. As amostras serão coletadas durante a doação de sangue na sala de coleta da Unidade da Fundação Hemominas de Poços de Caldas, onde serão identificadas, posteriormente serão encaminhadas ao, setor de distribuição onde serão centrifugadas, para envio ao Laboratório de Apoio - Policlínica Central de Poços de Caldas. Após a análise, as amostras retornarão para a unidade onde irão compor o biorrepósitório até o término da pesquisa.

2.1 As amostras serão transportadas em caixa térmica para transporte de amostras com temperatura controlada.

3. O material biológico constituinte do biorrepositório será mantido na sala de armazenamento de hemocomponentes não liberados e amostras da Unidade da Fundação Hemominas.

3.1. As amostras de ferritina serão armazenadas em tubo tipo EPPENDORF no freezer Thermo Scientific REVCO Patrimônio $n^{\circ} 3576997-1$ a menos $30^{\circ} \mathrm{C}$ em prateleira identificada até o término da pesquisa. 
3.2 As amostras de hemograma serão armazenadas no tubo primário na câmara de conservação Modelo 347 FANEM Patrimônio no $1890874-8$ na temperatura de 2 a $6^{\circ} \mathrm{C}$ em prateleira identificada até o termino da pesquisa.

4. O prazo de armazenamento do biorrepositório será o mesmo da pesquisa, definido no cronograma do projeto de pesquisa aprovado pelo Comitê de Ética em Pesquisa da Fundação Hemominas.

5. O biorrepositório estará sob a responsabilidade da pesquisadora é poderá ser supervisionado pelo Serviço de Pesquisa a qualquer momento;

6. Havendo a-retirada ou desistência por parte do participante de pesquisa referente às amostras coletadas e armazenadas, deverão a pesquisadora e a Fundação Hemominas disponibilizarem as amostras, nọ termos da regulamentação vigente. Nesse caso será facultado ao participante de pesquisa requerer as amostras ou solicitar que elas sejam destruídas pela pesquisadora;

7. Todos os materiais armazenados no Biorrepositório deverão ser destruídos ao final do projeto de pesquisa.

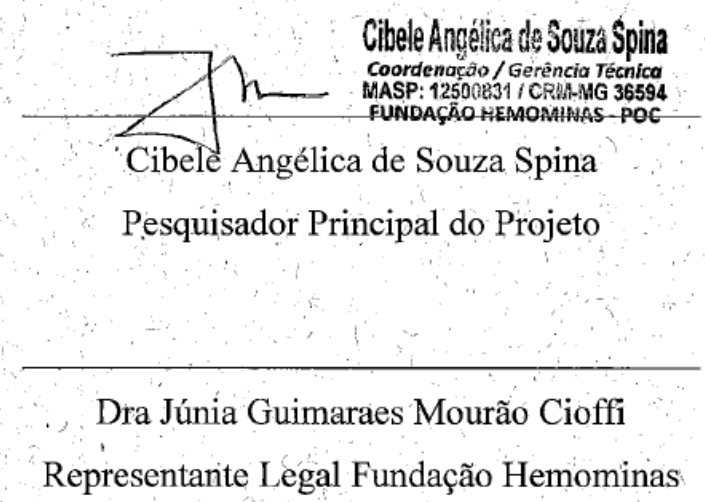

Daniel Gonçalves Chaves

Chefia do Serviço de Pesquisa 


\section{FUNDAÇÃO HEMOMINAS-MG}

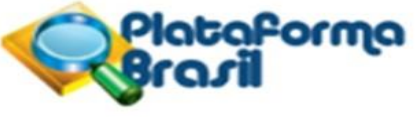

\section{ANEXO B - Parecer consubstanciado do CEP}

\section{PARECER CONSUBSTANCIADO DO CEP}

\section{DADOS DO PROJETO DE PESQUISA}

Título da Pesquisa: Sideropenia em doadores de sangue da Unidade da Fundação Hemominas de Poços de Caldas

Pesquisador: CIBELE ANGELICA SOUZA SPINA

Área Temática:

Versão: 2

CAAE: 00914918.5.0000.5118

Instituição Proponente: FUND CENTRO HEMATOLOGIA E HEMOTERAPIA DE MINAS GERAIS Patrocinador Principal: POÇOS DE CALDAS PREFEITURA

\section{DADOS DO PARECER}

\section{Número do Parecer: 3.064 .392}

\section{Apresentação do Projeto:}

Segundo os autores, este projeto destina-se a realizar uma análise prospectiva do status de ferro em doadores de sangue da unidade da Fundação Hemominas de Poços de Caldas. É sabido que em uma doação de aproximadamente $475 \mathrm{~mL}$ de sangue ocorre a depleção em média $242 \pm 17$ $\mathrm{mg} / \mathrm{dL}$ de ferro do doador, o que pode levar a consequências variáveis em suas reservas e na sua saúde. Esse trabalho tem como objetivo avaliar 1000 doadores de sangue na Unidade da Fundação Hemominas de Poços de Caldas, através da dosagem, no momento da doação, de ferritina sérica, hemoglobina e hematócrito, e comparar esses valores em doadores de sangue de primeira vez e de repetição, em ambos os sexos; e correlacionar com: a quantidade de doações, sexo dos doadores e tipo de alimentação do doador. Se, for observado que há depleção de ferro nos doadores de repetição, propor protocolos de atendimento para esse doador.

Uma das maiores preocupações dos grandes centros de hemoterapia no mundo é a segurança do doador e do paciente. Em 2014 o Brasil passou a fazer parte da rede mundial de hemovigilância, que tem como objetivo identificar riscos e melhorar a qualidade de processos e produtos, esse fato foi consolidado com o lançamento do Marco Conceitual em hemovigilância em 2015, antes dessa publicação a hemovigilância resumia-se a investigação e monitoramento das reações ocorridas durante ou após as transfusões. O marco amplia o escopo da hemovigilância uma vez que abrange todo ciclo do sangue. O Marco Conceitual trás um capítulo sobre a hemovigilância do doador, que pontua todos os eventos adversos imediatos que podem ocorrer antes, durante e após a doação de sangue. No entanto não aborda uma das principais reações tardias ao doador, que é a sideropenia em doadores de repetição. Isso já havia sido observado na década de 50 , quando em uma 
investigação do metabolismo do ferro em 297 doadores voluntários, verificou-se que a partir da décima doação haviam significativas diferenças entre doadores do sexo masculino e feminino, e em $22 \%$ destes últimos apresentavam sideropenia latente (VRIES 1958). Em outro estudo mais recente realizado no Centro de Medicina Laboratorial da Santa Casa de Limeira foram investigados 100 doadores aptos para doação de sangue, sendo 50 homens e 50 mulheres com idade entre 18 e 55 anos, sendo doadores de repetição ou de primeira vez. Foi realizada dosagem de ferritina, dosagem do ferro sérico e transferrina.

Observou-se que $26 \%$ dos doadores apresentavam ferro $<60,56 \%$ ferritina $<12$. E o autor conclui que a doação de sangue pode causar uma deficiência de ferro nos doadores, em especial nas mulheres que doam mais de uma vez por ano (BRANDINO, 2007). No entanto, a depleção do ferro no organismo, também conhecida como sideropenia, pode ocorrer em outras situações como: dietas pobre de ferro, verminoses, síndromes de má absorção, hemorragias, hematúrias, hemorroidas, câncer e úlceras. É importante identificar no doador a presença dessas situações para poder afirmar que a doação por si só leva a esse quadro. Já foi demonstrado que doadores de sangue perdem em torno de $242 \pm 17 \mathrm{mg}$ de ferro em cada doação (BRANDINO,2007). Se um doador tem estoques de ferro normais, a perda ocorrida em uma doação diminuirá os estoques corporais de ferro. Ratificando esse conceito, diversos autores têm mostrado que doadores de sangue apresentam reservas de ferro menores do que os não doadores. A demanda por ferro aumenta com doações repetidas, podendo levar maior frequência de deficiência de ferro observada nestes indivíduos. Segundo Boultron, a depleção de ferro é uma consequência inevitável da doação de sangue. A dosagem de ferritina permanece ainda, segundo vários autores, dentre eles Mousinho et al., , o melhor marcador para estimar os estoques de ferro, sendo que a técnica imunoenzimática consagrada por ser automatizada e de maior confiabilidade. Uma vantagem da dosagem da ferritina é a relativa estabilidade observada em repetidas avaliações em uma pessoa. Em indivíduos com deficiência de ferro não complicada, foram registrados valores médios de 3 a $6 \mathrm{ng} / \mathrm{L}$, sendo raros os valores superiores a $12 \mathrm{ng} / \mathrm{L}$. Desse modo, em ambos os sexos, o valor que separa indivíduos normais dos deficientes parece ser de 10 a $12 \mathrm{ng} / \mathrm{L}$.

Este trabalho teve o objetivo principal de verificar, prospectivamente, se doadores de sangue da Unidade da Fundação Hemominas de Poços de Caldas desenvolvem sideropenia sem anemia após doações consecutivas.

Hipótese: $O$ doador de sangue de repetição desenvolve sideropenia sem anemia?

Metodologia Proposta:

Serão analisados indivíduos que procuraram a unidade da Fundação Hemominas em Poços de Caldas de segunda a sexta-feira das 07 às 11:30, às quartas-feiras das 16 às 20:00 e no primeiro sábado de setembro. E também os doadores do Posto de Coleta Externa de Varginha às sextasfeiras das 07às 11:30, no período de 01 de setembro de 2018 a 31 de outubro de 2018, ou até serem completados mil candidatos. Na triagem clínica os doadores são investigados quanto às seguintes variáveis, já fazendo parte do protocolo da instituição:

- Uso de medicamentos (inibidores de bomba);

- Parasitoses intestinais; 
- Sangramento no tubo digestivo: crônicos ou agudos;

- Síndrome de má absorção intestinal;

- Doença celíaca;

- Epistaxe;

- Doenças descamativas da pele;

Será acrescentado questionário visando identificar fontes de ingesta e depleção de ferro.

Critério de Inclusão:

- Doadores ambos os sexos considerados aptos para doação de acordo com a Portaria Ministerial no 158 de 4/02/2016

Critério de Exclusão:

- Doadores com idade inferior a 18 anos;

- Doadores com idade superior a 60 anos;

- Doadores ambos os sexos considerados inaptos para doação de acordo com a Portaria Ministerial no 158 de 4/02/2016;

- Doadores que não queiram participar da pesquisa.

\section{Objetivo da Pesquisa:}

Objetivo Primário:

- Investigar, prospectivamente, a incidência de sideropenia nos doadores de sangue.

Objetivo Secundário:

- Comparar os níveis de ferritina, hemoglobina e hematócrito em doadores de sangue de primeira vez e de repetição em ambos os sexos; e correlacionar com: a quantidade de doações, sexo dos doadores e tipo de alimentação do doador; avaliar os índices de hemoglobina e hematócrito e verificar se há correlação com a ferritina sérica; Verificar em qual percentual o intervalo recomendado entre doações é o ideal para ambos os sexos; Propor medidas para a segurança do doador quanto à depleção do ferro.

\section{Avaliação dos Riscos e Benefícios:}

Os riscos apontados pelos autores são a ocorrência de reações adversas da coleta de uma amostra adicional.

Os beneficos relacionados são:

- Conhecer o perfil da cinética de ferro dos doadores;

- Adotar medidas corretivas para a deficiência de ferro;

- Adotar medidas preventivas para grupos de doadores vulneráveis.

\section{Comentários e Considerações sobre a Pesquisa:}

Trata-se de projeto relevante e conectado com a realidade das doações de sangue após a implantação do Marco Conceitual, onde de forma explicita a segurança do doador para além dos incidentes infecciosos tornou-se um dos focos de atuação das equipes envolvidas 


\section{Considerações sobre os Termos de apresentação obrigatória:}

Vide item "Conclusões ou pendências e lista de inadequações.

\section{Recomendações:}

Vide item "Conclusões ou pendências e lista de inadequações

\section{Conclusões ou Pendências e Lista de Inadequações:}

O projeto é relevante e apresenta bastante clareza de objetivos. Este comitê solicita apenas a adequação em alguns aspectos:

1."Posto que haverá coleta adicional de sangue para a realização de exames hematológicos e bioquímicos, haverá guarda de amostras e consequente formação de biorrepositório. Informamos que ocorrendo a formação do biorrepositório deverá ser apresentado termos de composição do mesmo conforme a resolução CNS 441 de 12/05/2011. A pesquisadora poderá entrar em contato com o CEP para solicitar os documentos necessários para adequação. Deverá ainda apresentar os termos de composição do biorrepositório e incluir no TCLE as disposições relativas à formação do biorrepositório."

RESPOSTA: Entrei em contato com o CEP e solicitei os documentos necessários para adequações, porém fui orientada a buscar o documento nas resoluções citadas. No anexo I dessa resposta consta o Regimento do Biorrepositório. Foi acrescido no TCLE as considerações quanto ao biorrepositório (Anexo II).

ANÁLISE: PENDÊNCIA ATENDIDA.

\section{2." Em qual laboratório serão realizados os exames?}

RESPOSTA: Serão custeados por alguma das instituições participantes? Posteriormente à postagem dos documentos na Plataforma Brasil foi enviada ao CEP carta da Secretaria de Saúde de Poços de Caldas. Nesta carta o Secretário especifica o compromisso da Prefeitura em realizar os exames (dosagem de ferritina e hemograma). Essa carta física enviada diretamente ao CEP deverá ser juntada na plataforma. Ressalta-se ainda que a Prefeitura de Poços de Caldas deverá compor o Projeto como instituição coparticipante, devendo a pesquisadora adequar os documentos apresentados na PB, incluindo um membro da Prefeitura, caso ainda não haja. "

Os exames serão realizados no Laboratório da Policlínica Central - Secretaria Municipal de Saúde.

Conforme carta de anuência de 26/10/2018 todos os testes serão custeados pela Secretaria Municipal de Saúde., cujo documento está anexado na Plataforma Brasil. Foi incluído membro da prefeitura na plataforma.

ANÁLISE: PENDÊNCIA ATENDIDA.

3. Deverá ser explicitado como os doadores terão acesso aos resultados, bem como esclarecidas as

Página 05 de informações relativas a obtenção de informações adicionais para esclarecimento de alterações nos resultados. A pesquisadora deverá apresentar a forma como os doadores terão acesso aos resultados e quem/como solucionará eventuais dúvidas que possam surgir.

RESPOSTA: Conforme novo TCLE: "Os resultados dos exames coletados, ferritina e hemograma, estarão disponíveis na unidade a partir de 30 dias após a coleta, e poderá ser consultado a 
qualquer momento durante o horário de atendimento, pelo pesquisador. No caso de alterações em quaisquer exames, você será comunicado através de convocação para comparecer na unidade e será atendido pela pesquisadora responsável. Havendo correlação clínica com os resultados obtidos, você será encaminhado para a unidade básica de saúde de referência para diagnóstico, tratamento e acompanhamento ambulatorial, de forma gratuita e pelo tempo que se fizer necessário., conforme fluxo já existente na unidade. "Ainda sobre este item, na brochura no subitem 3.3 - Métodos Laboratoriais:

• Dosagem de Ferritina: o parágrafo não foi concluído. "Estas análises serão....":

RESPOSTA DA AUTORA PRINCIPAL: Foram realizadas modificações no item todo:

\subsection{MÉTODOS LABORATORIAIS}

- Dosagem de hemoglobina e hematócrito

Será realizada em contador automatizado de células (BC 580 MINDRAY) com uso de uma amostra de sangue periférico coletada no momento da doação, juntamente com as amostras da triagem de rotina, amostras coletadas em tubo com anticoagulante EDTA - K3, no mínimo $3 \mathrm{ml}$, identificadas através do sistema ISBT, que após análise no laboratorio de apoio - Laboratório da Policlínica Central serão devolvidas para a unidade e armazenadas no tubo primário sob refrigeração de 2 a $6^{\circ} \mathrm{C}$ até o término da pesquisa, porém as amostras apresentarão estabilidade confiável até 24 horas após a coleta, conforme descrito no regimento do biorreservatório constituído para fins dessa pesquisa.

- Dosagem de ferritina

A dosagem de ferritina sérica será determinada de forma quantitativa no soro dos doadores com uso da metodologia de Imunoturbidimetria, determinação de ponto final da concentração da ferritina através de medição fotométrica da reação antígeno-anticorpo, entre partículas de látex marcadas com anticorpo antiferritina e ferritina presente na amostra, no aparelho BS300 MINDRAY. As amostras serão coletadas em tubo seco com gel separador no mínimo $2 \mathrm{ml}$, identificadas através do sistema ISBT, que serão centrifugadas, analisadas, separadas, e posteriormente enviadas para o laboratorio de apoio - Laboratório da Policlínica Central para realização do exame através do soro, armazenado em tubo tipo EPPENDORF de $2 \mathrm{ml}$ identificado através do sistema ISBT, e devolvido para a unidade onde será congelado a menos $20^{\circ} \mathrm{C}$ até o término da pesquisa, conforme descrito no regimento do biorreservatório constituído para fins dessa pesquisa.

ANÁLISE: PENDÊNCIA ATENDIDA.

4. De acordo com o cronograma, as coletas já tiveram inicio. De acordo com a brochura, onde o projeto está detalhado:

- Subitem 3.1.1: Desenho e Seleção de Amostra....

"Serão analisados indivíduos que procuraram a unidade da Fundação Hemominas em Poços de Caldas de segunda a sexta-feira das 07 às 11:30, às quartas-feiras das 16 às 20:00 e no primeiro sábado de setembro. E também os doadores do Posto de Coleta Externa de Varginha às sextasfeiras das 07às 11:30, no período de 01 de setembro de 2018 a 31 de outubro de 2018, ou até serem completados mil candidatos. Pelo desenho do estudo, os doadores já estariam sendo recrutados antes da aprovação do CEP da Fundação Hemominas. Entretanto qualquer estudo só 
poderá ter início após a aprovação do Comitê de Ética em Pesquisa competente, conforme resolução 466/12.

RESPOSTA: As coletas não foram iniciadas. Quando o projeto foi encaminhado ao CEP acreditavase que o cronograma original poderia ser seguido, e ainda apenas em outubro foi definido o parceiro para a execução dos exames. O cronograma foi adequado e apresentado na brochura e na carta resposta.

ANÁLISE: PENDÊNCIA ATENDIDA.

\section{Sobre o TCLE:}

5.1 mesmo encontra-se com erro de digitação da palavra Consentimento no título.

RESPOSTA: Corrigido. Vide anexo II

5.2. Não consta nome dos pesquisadores e seu contato no termo, bem como o endereço das instituições envolvidas, bem como seus respectivos contatos. Solicita-se adequação. (Manter e solicitar que incluam o contato do CEP também)

RESPOSTA: Corrigido. Vide anexo II

5.3. Conforme definido pela Resolução CNS 466/12, solicita-se que seja acrescentado ao TCLE o direito de assistência integral, gratuita e pelo tempo que se fizer necessário àqueles participantes que sofrerem danos relacionados à sua participação na pesquisa. (Manter e incluir também o direito à indenização).

RESPOSTA: Corrigido. Vide anexo II

5.4 CONSENTIMENTO PÓS INFORMADO: "Declaro para fins desta pesquisa clínica que fui esclarecido sobre seu objetivo e que concordo em participar dela voluntariamente, me sentindo livre para recusar ou retirar o meu conhecimento (consentimento?) em qualquer momento." (Foi usado o termo "conhecimento" ao invés de "consentimento").

RESPOSTA: Corrigido. Vide anexo II

6. Considerando que haverá uso de fontes secundárias de dados (prontuários, dados demográficos etc.) e que serão usadas as fichas de doação anteriores que estão arquivadas na Fundação Hemominas e também o sistema HEMOTE, solicita-se incluir no item "Riscos": quebra de confidencialidade de informações contidas nas fontes a serem consultadas e como esse risco será controlado. Incluir este risco no TCLE, conforme exigência a Resolução 466 de 12/12/2012. Adequar o TCLE em razão da formação de biorrepositório, conforme Resolução 441/2011.

RESPOSTA: Incluída consideração sobre o risco identificado, bem como medidas para controla-lo. Vide anexo II

ANÁLISE: PENDÊNCIA ATENDIDA. 


\section{Considerações Finais a critério do CEP:}

Prezado(a) pesquisador(a), seu projeto de pesquisa foi aprovado pelo CEP-Hemominas e, conforme definido pela Resolução CNS 466/12, deve ser acompanhado por meio de relatórios parciais e final. Solicitamos que relatórios parciais sejam apresentados a esse CEP a cada 12 meses a contar a partir da data de aprovação do projeto na Plataforma Brasil. O relatório final deve ser apresentado assim que a pesquisa for encerrada. Os relatórios devem seguir o padrão definido pelo Serviço de Pesquisa da Fundação Hemominas e o formulário a ser utilizado deve ser solicitado pelo e-mail secretaria.pesquisa@hemominas.mg.gov.br. Os relatórios devem ser preenchidos, assinados, digitalizados e submetidos na Plataforma Brasil como "Notificação" para serem analisados pelo CEP-Hemominas. Os(As) pesquisadores(as) que não submeterem seus relatórios serão considerados(as) inadimplentes.

Este parecer foi elaborado baseado nos documentos abaixo relacionados:

\begin{tabular}{|c|c|c|c|c|}
\hline Tipo Documento & Arquivo & Postagem & Autor & Situação \\
\hline $\begin{array}{l}\text { Informações Básicas } \\
\text { do Projeto }\end{array}$ & $\begin{array}{l}\text { PB_INFORMACCỎES_BÁSICAS_DO_P } \\
\text { ROJETO 920195.pdf }\end{array}$ & $\begin{array}{c}26 / 11 / 2018 \\
13: 06: 03\end{array}$ & & Aceito \\
\hline Parecer Anterior & Resposta_parecer.pdf & $\begin{array}{c}26 / 11 / 2018 \\
13: 05: 14 \\
\end{array}$ & \begin{tabular}{|l} 
CIBELE ANGELICA \\
SOUZA SPINA
\end{tabular} & Aceito \\
\hline $\begin{array}{l}\text { Declaração do } \\
\text { Patrocinador }\end{array}$ & Carta_anuencia.pdf & $\begin{array}{c}26 / 11 / 2018 \\
13: 04: 32 \\
\end{array}$ & $\begin{array}{l}\text { CIBELE ANGELICA } \\
\text { SOUZA SPINA }\end{array}$ & Aceito \\
\hline $\begin{array}{l}\text { Declaração de } \\
\text { Manuseio Material } \\
\text { Biológico / } \\
\text { Biorepositório / } \\
\text { Biobanco }\end{array}$ & Biorrepositorio.pdf & $\begin{array}{c}26 / 11 / 2018 \\
13: 02: 06\end{array}$ & $\begin{array}{l}\text { CIBELE ANGELICA } \\
\text { SOUZA SPINA }\end{array}$ & Aceito \\
\hline Brochura Pesquisa & Projeto_detalhado_novo.pdf & $\begin{array}{c}26 / 11 / 2018 \\
12: 55: 04\end{array}$ & $\begin{array}{l}\text { CIBELE ANGELICA } \\
\text { SOUZA SPINA }\end{array}$ & Aceito \\
\hline $\begin{array}{l}\text { TCLE / Termos de } \\
\text { Assentimento / } \\
\text { Justificativa de } \\
\text { Ausência }\end{array}$ & TCLE_novo.pdf & $\begin{array}{c}26 / 11 / 2018 \\
12: 53: 34\end{array}$ & $\begin{array}{l}\text { CIBELE ANGELICA } \\
\text { SOUZA SPINA }\end{array}$ & Aceito \\
\hline $\begin{array}{l}\text { Projeto Detalhado / } \\
\text { Brochura } \\
\text { Investigador }\end{array}$ & projeto_brochura.pdf & $\begin{array}{c}04 / 10 / 2018 \\
18: 36: 26\end{array}$ & $\begin{array}{l}\text { CIBELE ANGELICA } \\
\text { SOUZA SPINA }\end{array}$ & Aceito \\
\hline Outros & questionario.pdf & $\begin{array}{c}03 / 08 / 2018 \\
17: 52: 25\end{array}$ & $\begin{array}{l}\text { CIBELE ANGELICA } \\
\text { SOUZA SPINA }\end{array}$ & Aceito \\
\hline $\begin{array}{l}\text { Declaração de } \\
\text { Instituição e } \\
\text { Infraestrutura }\end{array}$ & cadastro_pesquisa.pdf & $\begin{array}{c}03 / 08 / 2018 \\
17: 36: 53\end{array}$ & $\begin{array}{l}\text { CIBELE ANGELICA } \\
\text { SOUZA SPINA }\end{array}$ & Aceito \\
\hline $\begin{array}{l}\text { Declaração de } \\
\text { Pesquisadores }\end{array}$ & termo_de_compromisso.pdf & $\begin{array}{c}03 / 08 / 2018 \\
17: 34: 05\end{array}$ & $\begin{array}{l}\text { CIBELE ANGELICA } \\
\text { SOUZA SPINA }\end{array}$ & Aceito \\
\hline Folha de Rosto & folha_de_rosto.pdf & $\begin{array}{c}03 / 08 / 2018 \\
17: 27: 36\end{array}$ & $\begin{array}{l}\text { CIBELE ANGELICA } \\
\text { SOUZA SPINA }\end{array}$ & Aceito \\
\hline
\end{tabular}

\section{Situação do Parecer:}

Aprovado

\section{Necessita Apreciação da CONEP:}

Não

BELO HORIZONTE, 07 de Dezembro de 2018

\section{Assinado por:}

Tatiana Balaguer Abramo Mendes

(Coordenador(a)) 